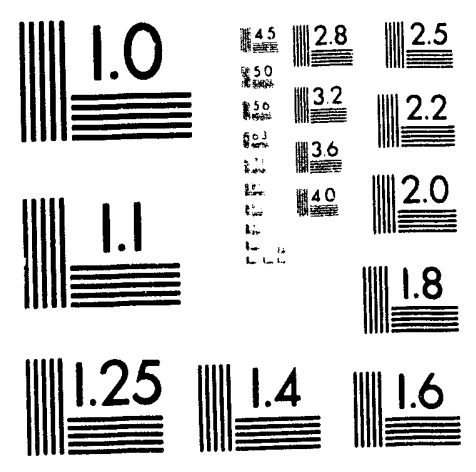



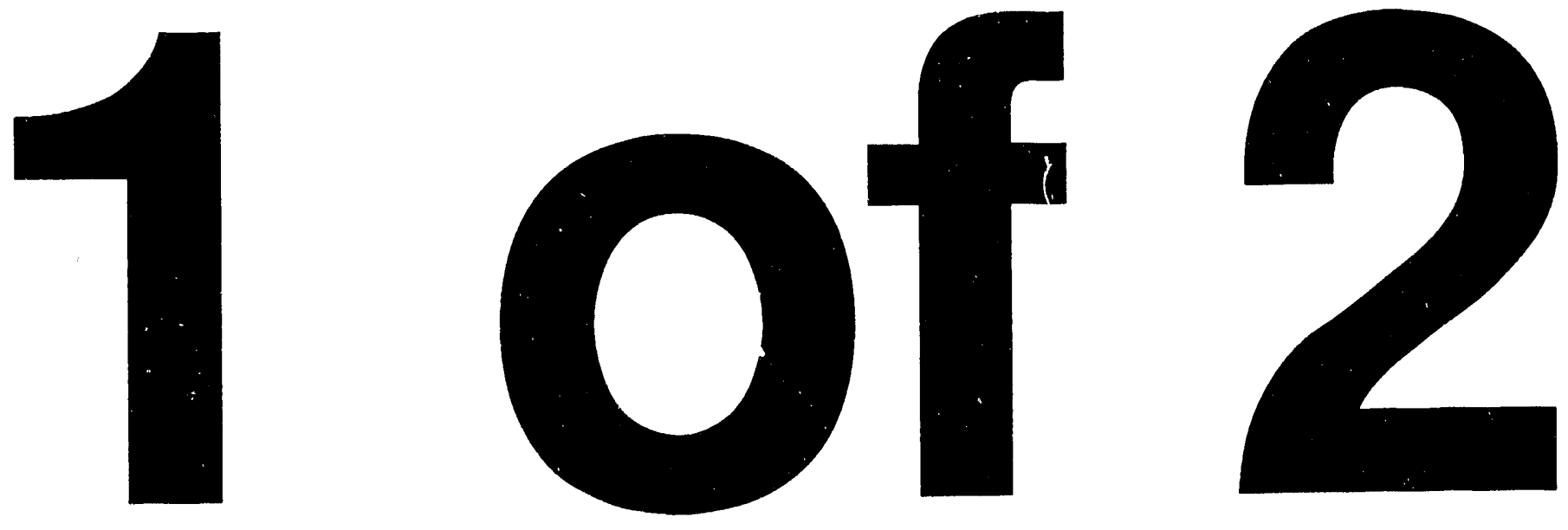


\title{
X-231B Technology Demonstration for In Situ Treatment of Contaminated Soil: \\ Technology Evaluation and Screening
}

\author{
R. L. Siegrist 1 \\ M. I. Morris 2 \\ T. L. Donaldson 2 \\ A. V. Palumbo ${ }^{1}$ \\ S. E. Herbes 1 \\ R. A. Jenkins ${ }^{3}$ \\ C. M. Morrissey 1 \\ M. T. Harris 2 \\ Environmental Sciences Division \\ Publication No. 3820 \\ Date Prepared: December 1990 - February 1991 \\ Date Published: August 1993 \\ Prepared For \\ U.S. DEPARTMENT OF ENERGY \\ Portsmouth Gaseous Diffusion Plant \\ Piketon, Ohio \\ Prepared By \\ OAK RIDGE NATIONAL LABORATORY \\ P.O. Box 2008 \\ Oak Ridge. Tennessee 3783()-6036 \\ Managed by \\ MAR'TIN MARIETTA ENERGY SYSTEMS, INC. \\ for the \\ U.S. DEPARTMENT OF ENERGY \\ Under Contract DE-AC05-84OR21400
}

\footnotetext{
1 Environmental Sciences Division, ORNL

2 Chemical Technology Division, ORNL

${ }^{3}$ Analytical Chemistry Division, ORNL
} 


\section{CONTENTS}

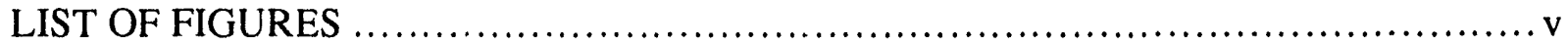

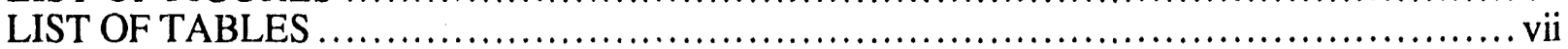

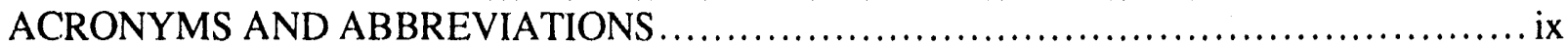

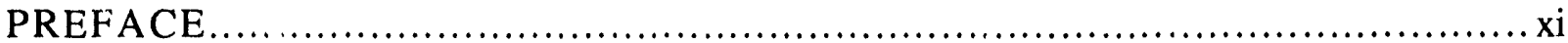

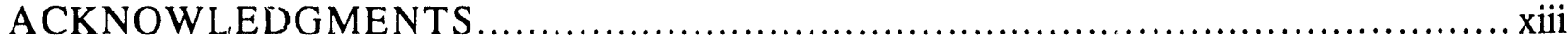

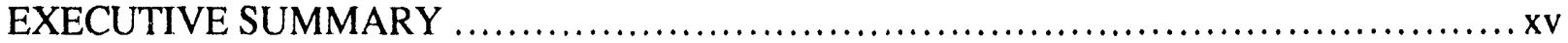

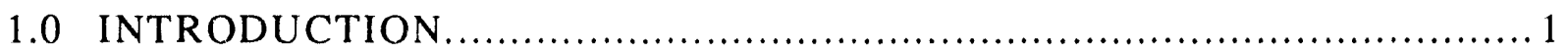

2.0 SYNOPSIS OF EXISTING CONDITIONS ........................................... 7

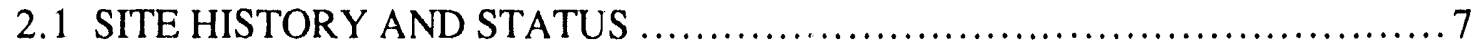

2.2 SITE PHYSICAL CHARACTERISTICS ................................... 7

2.2 .1 Setting ..............................................................

2.2.2 Soil and Geology ................................................ 7

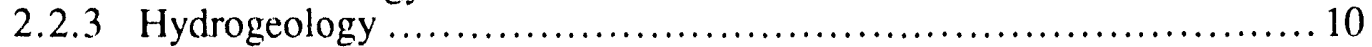

2.3 SITE CONTAMINATION CHARACTERISTICS ............................... 10

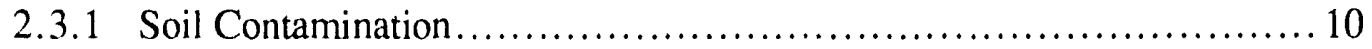

2.3.2 Groundwater Contamination.................................... 11

3.0 PROBLEM DEFINITION AND PERFORMANCE CRITERIA ........................ 17

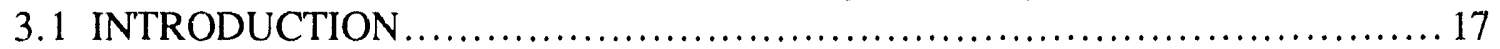

3.2 MATERIALS AND METHODS ................................................. 17

3.3 RESULTS AND DISCUSSION..................................................... 17

3.3.1 Problem Domain....................................................... 17

3.3.2 Performance Criteria Assumptions for Technology Evaluation and Screening ..................................................... 19

3.3.3 Performance Criteria Development During Technology Demonstration . 19

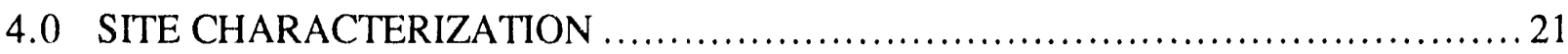

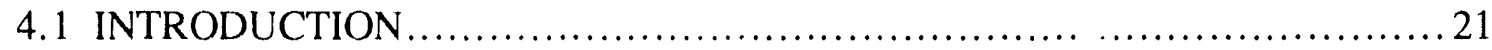

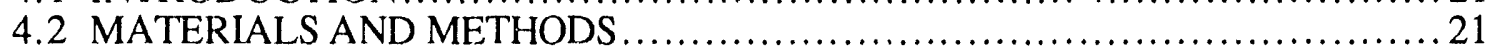

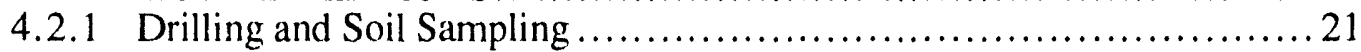

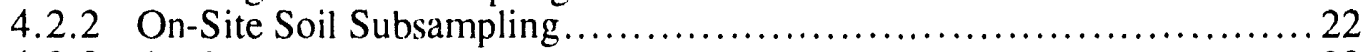

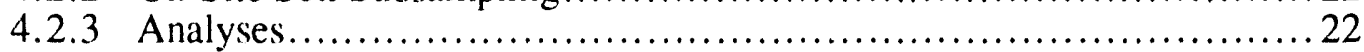

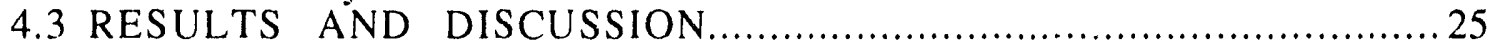

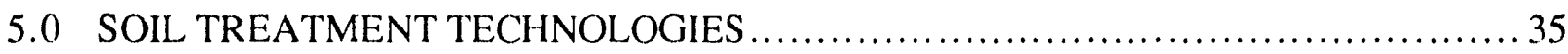

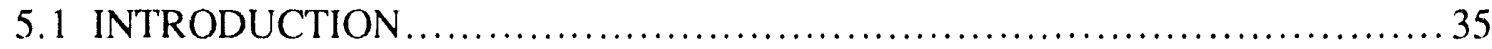

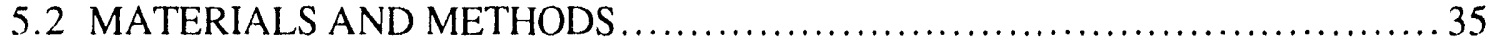

5.2 .1 Technology Descriptions .......................................... 35

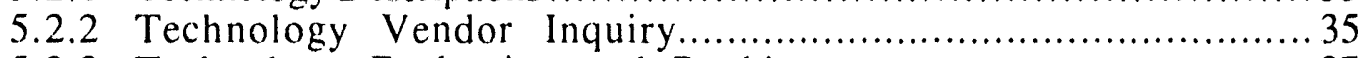

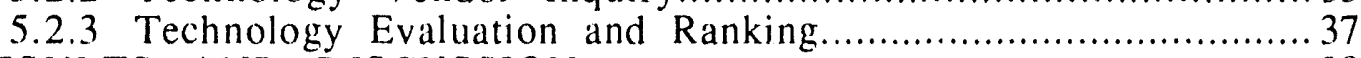

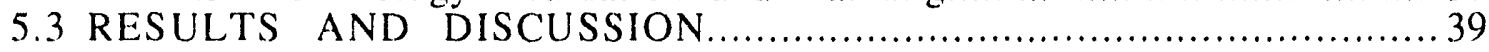

5.3.1 Technology Descriptions ......................................... 39

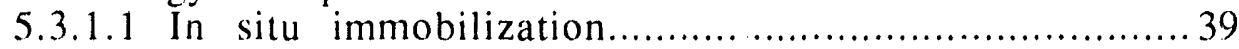

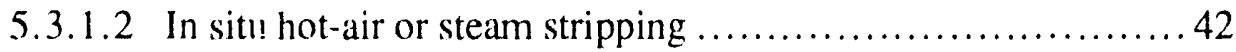




\section{CONTENTS (cont.)}

Page

5.2 .1 .3 In situ electrokinetics .................................. 44

5.3 .1 .4 In situ slurry jet reactor.................................. 44

5.3.1.5 In situ $\mathrm{EM} / \mathrm{RF}$ soil heating ........................... 44

5.3.1.6 In situ / ex situ hydrogen peroxide treatment ............... 45

5.3.1.7 Ex situ thermal treatment .................................... 45

5.3 .1 .8 Ex situ immobilization ................................... 45

5.3 .2 Technology Vendors......................................... 46

5.3.3 Technology Evaluation and Ranking.................................... 46

5.3.4 Technology Demonstration Strategy ............................. 50

6.0 TECHNOLOGY DEMONSTRATION, TESTING, AND EVALUATION .............. 53

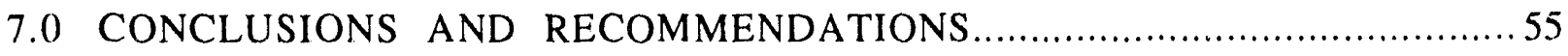

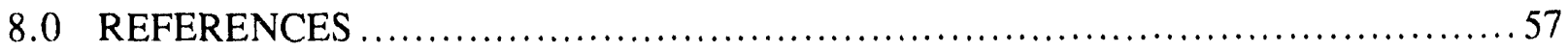

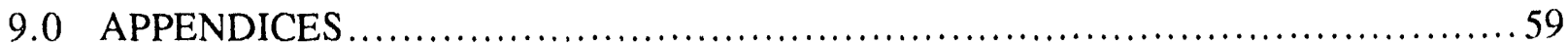

APPENDIX A. SITE CHARACTERIZATION SOIL BORING LOGS $\ldots \ldots \ldots \ldots \ldots 61$

APPENDIX B. SOIL VOC ANALYSES DATA ............................... 67

APPENDIX C. TECHNOLOGY VENDOR REQUEST FOR INFORMATION ......71

APPENDIX D. TECHNOLOGY ASSESSMENT SCREENING INFORMATION ... 77

APPEI IDIX E. RESULTS OF TECHNOLOGY RANKING PROCESS ............. 91 


\section{LIST OF FIGURES}

Figure

Page

1.1. Location of the DOE Portsmouth Gaseous Diffusion Plant and the X-231B Unit ...... 3

1.2. Photograph of $\mathrm{X}-231 \mathrm{~B}$ oil biodegradation unit before the interim cap was placed in

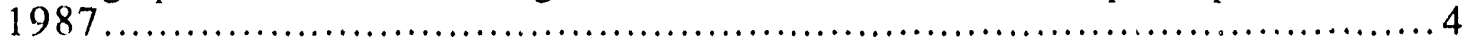

2.1. Map of the X-231B unit indicating its areal extent and the location of various utilities ................................................................. 8

2.2. Stratigraphic cross-section of the $\mathrm{X}-231 \mathrm{~B}$ site................................ 9

2.3. Stratigraphic cross-section of X-231B indicating spatial variability in soil VOC

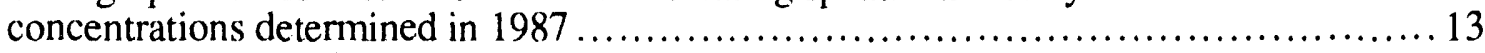

2.4. Map of X-231B indicating extent of groundwater contamination by TCE in the

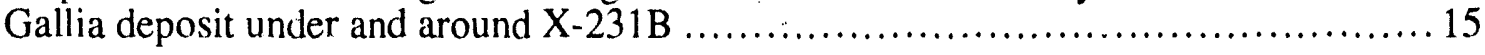

3.1. Schematic of the contaminated soil problem domain at the $\mathrm{X}-231 \mathrm{~B}$ site................. 18

4.1 Site map of X-231B indicating the location of three ORNL soil borings made to enable site characterization. ................................................... 22

4.2 Schematic indicating soil VOC subsample locations within each 4-in.-long stainless

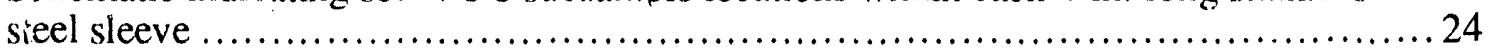

4.3. Stratigraphic cross section interpreted from soil borings made at the X-231B site by

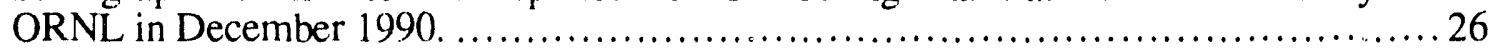

4.4. Concentrations of total soil VOCs measured by conventional and modified techniques in soil samples collected at the X-231B site by ORNL in December 1990

5.1. Graphical illustration of the weightings assigned to each of the technology "wants".

5.2. Graphical illustration of the results of the technology evaluation and ranking 


\section{LIST OF TABLES}

Table

Page

1.1. List of candidate technologies for demonstration at the X-231B oil biodegradation

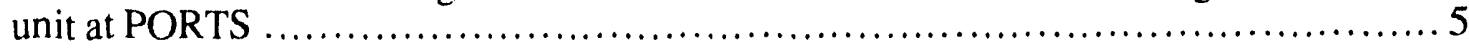

2.1. Summary of soil contamination levels with depth below X-231B $\ldots \ldots \ldots \ldots \ldots \ldots \ldots \ldots 12$

2.2. Summary of ground water contaminant concentrations at X-231 B . . . . . . . . . . . . . . . . 14

4.1. Soil percent moisture at the X-231B site as measured in soil samples collected by ORNL in December 1990 ................................................... 28

4.2. Characteristics of subsurface soil at the X-231B site as measured in samples collected by ORNL in December 1990 .

4.3. Headspace VOC concentrations in soil samples collected at X-231B by ORNL in December 1990 ............................................................... 30

4.4. Average concentrations of principal VOCs at the X-231B site as measured in soil

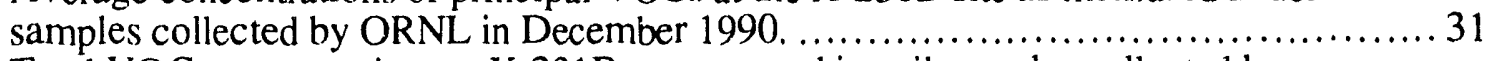

4.5. Total VOC concentrations at X-231B as measured in soil samples collected by

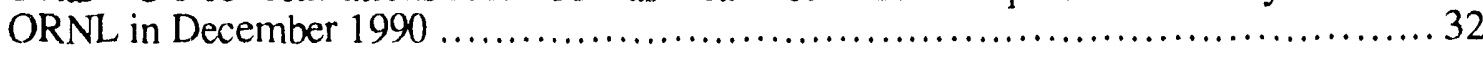

5.1. Revised list of candidate soil treatment technologies for demonstration at the ........... 36

5.2. Staff involved in the evaluation and ranking of candidate technologies for demonstration at the $\mathrm{X}-231 \mathrm{~B}$ site.

5.3. Summary of the decision framework used in evalıating candidate technologies for demonstration at the X-231B site.......................................................4 40

5.4. Summary of the key features of the candidate technologies evaluated. ................ 41

5.5. Summary of vendors responding by candidate technology or process category............47

5.6. Summary of weighting values used for each of the technology "wants" ............... 48

5.7. Summary of the rank scoring for each want for each of the candidate technologies ...... 51

6.1. Summary of Phase 2 activities and schedule for technology demonstration, testing and evaluation at PORTS X-231B. ......................................... 53

B.1. Laboratory reported results of GC/MS analysis of VOCs in soil samples collected from the X-231B site during December 1990 .

B.2. Converted results of GC/MS analysis of soil samples collected from the X-231B site during December 1990........................................................... 70

E.1. X-231B Plot soil remediation demonstration Kepner-Tregoe analysis wants weighting summary ........................................................... 93

E.2. Summary of X-231 B demonstration Kepner -Tregoe analysis ...................... 94

E.3. Summary of Kepner-Tregoe results for in situ immobilization ...................... 95

E.4. Summary of Kepner-Tregoe results for in situ air/steam stripping .................... 96

E.5. Summary of Kepner-Tregoe results for in situ electrokinetics...................... 97

E.6. Summary of Kepner-Tregoe results for in situ slurry reactor...................... 98

E.7. Summary of Kepner-Tregoe results for in situ RF/EM heating........................... 99

E.8. Summary of Kepner-Tregoe results for in situ / ex situ peroxide stripping .............. 100

E.9. Summary of Kepner-Tregoe results for ex situ thermal treatment ..................... 101

E.10. Summary of Kepner-Tregoe results for ex situ immobilization............................. 102 


$$
-\ldots
$$




\section{ACRONYMS AND ABBREVIATIONS}

\begin{tabular}{|c|c|}
\hline ASTM & - American Society Testing Materials \\
\hline CFU & Colony Forming Unit \\
\hline DCA & - 1,2-Dichloroethane \\
\hline DCE & - 1,2-Dichloroethylene \\
\hline DOE & - United States Department of Energy \\
\hline EPA & - United States Environmental Protection Agency \\
\hline ESD & - Environmental Sciences Division \\
\hline $\mathrm{GC}$ & - Gas Chromatograph \\
\hline GW & - Groundwater \\
\hline $\mathrm{K}$ & - Hydraulic Conductivity \\
\hline $\mathrm{MC}$ & - Methylene Chloride \\
\hline $\mathrm{MeOH}$ & - Methanol \\
\hline MMES & - Martin Marietta Energy Systems, Inc. \\
\hline MP\&T & - Modified Purge and Trap Vial \\
\hline MS & - Mass Spectrometer \\
\hline MW & - Monitoring Well \\
\hline nd, ND & - Not Detected \\
\hline $\mathrm{NE}$ & - Northeast \\
\hline NEPA & - National Environmental Policy Act \\
\hline NPDES & - National Pollutant Discharge Elimination System \\
\hline OEPA & - Ohio Environmental Protection Agency \\
\hline ORNL & - Oak Ridge National Laboratory \\
\hline ORNL/ESD & - Oak Ridge National Laboratory/Environmental Science Division \\
\hline ORNL/PAG & - Oak Ridge National Laboratory/Pollutant Assessments Group \\
\hline OSHA & Occupational Safety and Health Administration \\
\hline PID & - Photoionization Detector \\
\hline PORTS & - Portsmouth Gaseous Diffusion Plant \\
\hline $\mathrm{ppm}_{\mathrm{V}}$ & - Parts Per Million Volumetric \\
\hline QA/QC & - Quality Assurance/Quality Control \\
\hline QAPP & - Quality Assurance Project Plan \\
\hline RCRA & - Resource Conservation and Recovery Act \\
\hline$R \& D$ & - Research and Development \\
\hline RF & - Radiofrequency \\
\hline RFI & - RCRA Facilities Investigation \\
\hline $\mathrm{R} / \mathrm{O} / \mathrm{M}$ & - Reliability/Operability/Maintainability \\
\hline & - Soil Boring \\
\hline SVOC & - Semivolatile Organic Compound \\
\hline SW & - Southwest \\
\hline TCE & - Trichloroethylene \\
\hline TOC & - Total Organic Carbon \\
\hline TCA & - 1,1,1-Trichloroethane \\
\hline USDA & - U.S. Department of Agriculture \\
\hline UT & - University of Tennessee \\
\hline VOA & - Volatile Organic Acid \\
\hline VOC & - Volatile Organic Compound \\
\hline
\end{tabular}




\section{PREFACE}

Fine-textured soils and sediments contaminated by trichloroethylene (TCE) and other chlorinated organics present a serious environmental restoration challenge at U.S. Department of Energy (DOE) sites. Although in situ processes such as bioremediation and soil vapor extraction are feasible at sites with permeable soils (e.g., $\mathrm{K}>10^{-3} \mathrm{~cm} / \mathrm{s}$ ), their application is normally infeasible in wet, clay soils, and sediments. Environmental restoration of these sites has normally consisted of either (1) excavation and on-site storage, off-site land filling, or thermal treatment; or (2) inplace containment by capping and slurry wall emplacement.

In November 1990, DOE and Martin Marietta Energy Systems, Inc. initiated a research and demonstration project at Oak Ridge National Laboratory (ORNL). The goal of the project was to demonstrate a feasible and cost-effective process for closure and environmental restoration of the X-231B Solid Waste Management Unit at the DOE Portsmouth Gaseous Diffusion Plant located in southern Ohio. The X-231B Unit was used from 1976 to 1983 as a land disposal site for waste oils and solvents. Silt and clay deposits $\left(\mathrm{K}<10^{-6} \mathrm{~cm} / \mathrm{s}\right)$ beneath the unit were contaminated with volatile organic compounds (VOCs) such as TCE (approx. 1-100 ppm range) and low levels of radioactive substances. The shallow groundwater (water table at approx. 12-14 ft depth) was also contaminated, and some contaminants were at levels well above drinking water standards.

After an initial technology evaluation and screening phase, the X-231B project focused on research and demonstration of in situ vapor stripping, chemical oxidation, and solidification; and reagent delivery to the subsurface was achieved by soil mixing techniques. The primary objectives of the project were to develop processes as necessary and appropriate and to characterize the operation and performance of each process with regard to in situ treatment of VOCs in clay soils. Secondary objectives were to determine the treatment process zone of influence; the treatment process effects on air emissions, soil chemistry, and microbiology properties; and the fate of heavy metal and radioactive materials. Soil homogenization and translocation were also studied.

Since July 1991 varied research activities have been conducted. Site characterization and contaminant modeling work has included use of a hydraulic probe for collection of nearly 200 soil samples with on-site laboratory analysis for target VOCs. These data were used for statistical simulation and 3-dimensional modeling of contaminant distribution. A series of laboratory experiments were completed using bench-scale apparatus as well as a pilot-scale soil mixing system in which soil cores from the site were treated. A full-scale field demonstration was completed at the X-231B site in June 1992. Replicated tests of in situ vapor stripping, percxidation, and solidification were made in soil columns measuring $10 \mathrm{ft}$ in diameter and 15 to $22 \mathrm{ft}$ deep. A computerized data acquisition system linked to approx. 60 sensors enabled nearcontinuous monitoring of process operation and performance (e.g., recording intervals of 0.2 to 2 min. for auger position, off-gas air flow rate and VOC content, soil vapor pressure and temperature). In addition, nearly 500 soil and gas samples were collected before, during, and after soil treatment, for analyses of physical, chemical, and biological parameters. Soil matrix, soil vapor, and off-gas VOC measurements were made by multiple methods.

The X-231B project has been a multidisciplinary and multi-institutional, fast-track, applied research and demonstration effort. Directed by ORNL, the project has benefited from the significant contributions of research staff from six divisions at ORNL, technical and management staff at Portsmouth and Energy Systems, and principal collaborators from two universities (The University of Tennessee and Michigan Technological University) and several private industries (e.g., Chemical Waste Management, Millgard Environmental, Envirosurv, and NovaTerra). 
Results of the project have been very insightful regarding in situ environmental restoration of contaminated clay soils. For example, the use of a hydraulic probe for soil sampling with on-site VOC analyses, followed by 3-D visualization, provided enhanced information compared with conventional sampling, off-site analyses, and routine data treatment. In situ treatment of VOCs in clay soils was effectively (e.g., $>85 \%$ reduction) and rapidly accomplished (e.g., $>15 \mathrm{yd}^{3} / \mathrm{h}$ ) and the fate of VOCs and radioactive substances was controlled. Moreover, in situ treatment costs were acceptably low. Operation and performance did vary for the different processes evaluated, and there were advantages and disadvantages associated with each. Ancillary study results indicated interesting changes in soil properties following treatment. For example, soil bacteria levels were increased by several orders of magnitude following ambient air stripping. The favorable project results are being used to design and implement a cost-effective in situ treatment process for full-scale closure of the X-231B unit.

This report describes the methods and results of the first phase of the X-231B project, the technology evaluation and screening process. This Phase 1 work was completed during December 1990 and February 1991. Details regarding other aspects of the work are available in other project publications. Information regarding these publications may be obtained by contacting Dr. Robert L. Siegrist, Oak Ridge National Laboratory, P.O. Box 2008, Oak Ridge, TN, 37831-6036; 615574-7286. 


\section{ACKNOWLEDGMENTS}

Technical staff at ORNL and MMES provided outstanding support in completing the first phase of the X-231B project, a technology evaluation and screening effort, between November 1990 and March 1991. Without the financial support and assistance provided by The Department of Energy, Office of Environmental Restoration, and Martin Marietta Energy Systems, Inc., Environmental Restoration Division, this phase of the project could not have been accomplished. Described herein are the methods and results of the first phase of the project. This document was prepared between December 1990 and February 1991 and issued in draft form at that time to communicate the conclusions and recommendations of the project team at ORNL. The document subsequently received minor editorial revisions prior to publication in its current form.

The following ORNL staff are acknowledged for their contributions to this effort:
R. L. Siegrist (Project Technical Director)
M. I. Morris (Demonstration Coordinator)
T. L. Donaldson
S. E. Herbes
A. V. Palumbo
C. M. Morrissey
C. H. Brown
J. H. Wilson
M. T. Harris
N. E. Korte
D. A. Pickering
R. A. Jenkins
J. Zutman
Environmental Sciences Di : ision
Chemical Technology Division
Chemical Technology Division
Environmental Sciences Division
Environmental Sciences Division
Environmental Sciences Division
Chemical Technology Division
Chemical Technology Division
Chemical Technology Division
Environmental Sciences Division
Health and Safety Research Division
Analytical Chemistry Division
Oak Ridge Associated Universities

In addition to the above ORNL staff, other professional staff from ORNL and Energy Systems Environmental Restoration Division (ERD) participated in the technology screening and evaluation prccess:
C. P. McGinnis
J. S. Watson
R. L. Jolley
J. S. Baldwin
Waste R\&D Programs Office, ORNL Environmental Restoration Division, K-25 Chemical Technology, K-25 site Central Waste Management Division, K-25

The principal contact personnel within the Environmental Restoration Division at Energy Systems and PORTS include:

\author{
T. J. Newsom (ERD Project Manager) \\ R. O. Barnett, Jr. \\ J. McGee \\ R. D'Antoni
}

\author{
Environmental Restoration Division, K-25 \\ Environmental Restoration Division, PORTS \\ Environmental Restoration Division, PORTS \\ Engineering Division, PORTS
}

Significant input to this evaluation and screening was provided by numerous technology vendors through their responses to a technology survey. Geraghty \& Miller, Inc. is also acknowledged for their contribution to the site characterization component of the work. 


\section{EXECUTIVE SUMMARY}

During 1989 and 1990 efforts were made to close, per Resource Conservation and Recovery Act (RCRA) requirements, the X-231B oil biodegradation unit at the Portsmouth Gaseous Diffusion Plant (PORTS) [1-2]. This unit encompasses $\sim 0.8$ acres and was reportedly used from 1976 to 1983 for the treatment and disposal of waste oils and degreasing solvents. Existing site characterization data revealed that beneath the unit were fluviolacustrine silts and clays (Minford Member) underlain by silty sand and gravel at $\sim 25 \mathrm{ft}$ depth (Gallia Member) with the groundwater table at $\sim 10$ to $12 \mathrm{ft}$ depth. Groundwater flow occurred vertically through the Minford Member into the Gallia Member, where flow was predominant?y horizontal to the southeast [3]. Volatile organic compounds (VOCs) were present throughout the unconsolidated deposits under X-231B from the ground surface to $\sim 25 \mathrm{ft}$ depth $(3-4)$. These same contaminants were present in the shallow groundwater underneath and up to $750 \mathrm{ft}$ downgradient from the unit boundaries at levels well above federal drinking water standards. The primary VOCs were trichloroethene (TCE) and 1,1,1-trichloroethane (TCA).

Concerned over the continuous, long-term release of soil VOCs into the groundwater, the Ohio Environmental Protection Agency (OEPA) required that soil remediation be included in the closure of the unit. Due to the adverse characteristics of the soil and geologic materials and the depth and concentrations of VOCs present, initial attempts to identify a suitable soil treatment technology were unsuccessful. As a result, a team of scientists and engineers from Oak Ridge National Laboratory (ORNL) were assembled by the PORTS management contractor, Mart n Marietta Energy Systems, Inc. (Energy Systems), to examine the problem and identify potential innovative or alternative technologies for effective closure of the X-231 B unit. In October 199), several brainstorming sessions at ORNL led to the development of a "candidate list" of soil treatment technologies judged appropriate for further consideration. However, before implementing one or more technologies for full-scale remediation of the X-231B unit, it was concluded that a technology demonstration, testing, and evaluation project had to be completed.

The overali goal of the X-231B Technology Demonstration Project was to select and successfully demonstrate one or more technologies for effective treatment of the contaminated soils associated with the X-231B unit at PORTS. The project was divided into two major phases consisting of technology evaluation and screening (Phase 1) followed by technology demonstration, testing, and evaluation (Phase 2). The objectives of Phase 1 were to define the problem domain and performance criteria; delineate the constraints affecting implementation of the technology demonstration; and identify, evaluate, and recommend technologies judged to be capable of removing or immobilizing VOCs in the contaminated soils at the site. This report contains a discussion of the methods, results, and conclusions of the Phase 1 portion of the project. A synopsis of the findings is given below with complete details provided in the following sections.

The problem domain and performance criteria for technology screening and evaluation were established based on the existing conditions at X-231B, a knowledge of regulatory requirements and prior PORTS commitments, as well as consideration of the impacts of soil remediation on long-term groundwater monitoring and management. The problem domain was defined as the Minford Member from ground surface to a depth of up to $25 \mathrm{ft}$, extending horizontally to the boundaries of the $X-231 \mathrm{~B}$ unit. The preliminary performance criteria established were to either remove/destroy the soil VOCs to a total soil VOC concentration of less than $1 \mathrm{mg} / \mathrm{kg}$ or alternatively, to immobilize the VOCS so that the concentrations measured by a Toxicity Characteristic Leaching Procedure (TCLP) would be less than the toxicity characteristic thresholds. It was recognized that the problem domain and/or performance criteria could change due to new information gained later in the project. 
Field investigations were undertaken by ORNL during December 1990 to gather detailed site characterization data. Three borings were made in the northern plot of the X-231B unit, and subsurface conditions were observed and recorded to a depth of $24 \mathrm{ft}$. Soil samples were collected at multiple depths and analyzed for physical, chemical, and biological properties. The soil in the shallow unsaturated zone (Minford Member upper unit) was relatively moist (e.g., 15\% moisture), fine-grained media (i.e., $\geq 90 \%$ particles $\leq 50 \mu \mathrm{m}$ diameter) with a moderately acidic $\mathrm{pH}$. The total organic carbon content (TOC) was in the 0.05 to $0.10 \mathrm{wt} \%$ range. Nitrogen and phosphorus were present at concentrations of $\sim 0.050$ and $0.007 \mathrm{wt} \%$, respectively. In the saturated zone (Minford Member lower unit), the soil was coarser textured (i.e., $\geq 70 \%$ particles $\leq 50 \mu \mathrm{m}$ diameter) and neutral in $\mathrm{pH}$. In this zone, the silt and clay content were lower. The TOC was also lower although the nitrogen and phosphorus contents remained largely the same. Total bacteria were present at approximately $10^{4}$ to $10^{5}$ colony forming units per gram of soil in the shallow zone, although none were detected at depth. Similarly, methanotrophic bacteria were present in the shallow zone but were not detected at depth.

Thirteen VOCs were identified in the soil samples collected, with TCE, TCA, 1,1-dichloroethene (1,1-DCE), and methylene chloride (MC) being most prevalent and at the highest concentrations [i.e., several hundred to several thousand micrograms per kilogram (ppb)]. The highest concentrations were found in the unsaturated zone ( $7-\mathrm{ft}$ depth) near the center of the plot. Comparatively lower concentrations were found in the saturated zone $(\sim 17-\mathrm{ft}$ depth) and toward the edges of the plot. The VOCs identified and the concentrations measured in the ORNL site characterization work were in the range of those measured previously during 1986 and 1987. It appears, however, that the present concentrations may be somewhat lower, particularly within the saturated zone. This could be the result of VOC reductions due to leaching and/or degradation during the $\sim 3.3$ years between sampling events. Because the site has been covered with a geomembrane cap since late 1987 , it is unlikely that volatilization losses were significant.

Selection of the most promising technologies for demonstration at X-231B was accomplished by a rational ranking process. An inquiry was made to a selected number of technology vendors known to possess one or more of the candidate technologies. This was done to verify technology stage of development, performance capabilities, implementation constraints, and costs. This information revealed that a majority of the candidate technologies were commercially available but required demonstration at a site such as the X-231B unit. Using the data base available (e.g., the site characteristics, results of literature review and personal inquiries, and the vendor-supplied information), a rational process was used to rank the candidate technologies and facilitate development of the Phase 2 demonstration concept. This was accomplished by a team of thirteen scientists and engineers made up of the project technical team as well as several other ORNL and Energy Systems professionals. For this process, the technology demonstration objectives were first defined as "musts" and "wants." The musts were the minimum technical requirements each candidate technology had to satisfy. The wants were desirable but not absolutely required. These were delineated and weighted according to their perceived importance. Given detailed information describing the existing site conditions, problem domain, performance criteria, and the candidate technologies, each team member scored each of the technologies based on his/her assessment of the technologies capability to satisfy the project musts and wants. The technologies were then ranked according to their overall performance capabilities.

The project team concluded that the technology demonstration should consist of in situ soil mixing coupled with the injection of immobilization agents, hot air or steam, or hydrogen peroxide, either individually or in sequence. This approach would enable rigorous evaluation of in situ immobilization as well as removal/destruction processes, and would provide results regarding technology implementation, operation and maintenance, performance, and costs. These results could then be utilized for full-scale remediation of the X-231B Unit. Moreover, the results could be extended to other similar sites at PORTS, within the DOE system, and elsewhere. 


\subsection{INTRODUCTION}

The Portsmouth Gaseous Diffusion Plant (PORTS) is located approximately 70 miles south of Columbus in southern Ohio (Fig. 1.1). The facility occupies a 40()()-acre reservation and has been operational since 1954. Its primary mission is to enrich uranium for naval and commercial nuclear reactors $[2]$.

Among the several waste management units on the facility, the X-231B unit consists of two adjacent oil biodegradation plots (Figs. 1.1 and 1.2). The plots encompass $\sim(0.8$ acres and were reportedly used from 1976 to 1983 for the treatment and disposal of waste oils and degreasing solvents, some containing uranium-235 and technetium-99. The X-231B unit is a regulated solid waste management unit (SWMU) under the Resource Conservation and Recovery Act (RCRA). The X-231B unit is also a designated SWMU located within Quadrant I of the site as defined in an ongoing RCRA Facilities Investigation and Corrective Measures Study (RFI/CMS) [2].

During 1989 and 1990, efforts were made to close the X-231B unit per RCRA requirements. The unit was characterized by contamination in low-permeability soil and geologic materials to a depth of $\sim 25 \mathrm{ft}$, roughly half of which was below the groundwater table. The principal contaminants were trichloroethene, trichloroethane, and other volatile organic compounds (VOCs) |3-4). There were measurable, but low levels of uranium, technetium, and some heavy metals. The groundwater under and downgradient from the site was also contaminated by the same VOCs at levels well above drinking water standards. Concerned over the continuous, long-term release of soil VOCs into the groundwater, the Ohio Environmental Protection Agency (OEPA) required that soil remediation be included in the closure of the unit.

To facilitate evaluation of options for closure of X-231B, a Closure Options Study (COS) was completed for Energy Systems by Morrison Knudsen Corporation during November 1989 [1]. The recommendation made in the COS was that the remediation of the X-231B unit include a multimedia cap with an in situ soil vapor extraction system (SVES) and groundwater pumping and treatment. Unfortunately, subsequent treatability testing for the detailed design of the SVES revealed that the soil conditions at $\mathrm{X}-231 \mathrm{~B}$ were incompatible with this technology. As a result, the $\operatorname{COS}$ was revised to consider other remediation: alternatives [2].

Because of the adverse characteristics of the soil and geologic materials (wet, is w permeability) and the depth (up to $25 \mathrm{ft}$ ) and concentrations of VOCs present, Energy Systents was concerned that conventional alternatives for remediation might not be technically feasible and/or cost-effective. Thus, the Environmental Restoration Division (ERD) of Energy Systems requested that the Waste Research and Development (R\&D) Program Office at Oak Ridge National Laboratory (ORNL) assemble a team of scientists and engineers to examine the problem and try to identify a potential innovative or alternative technology to facilitate cost-effective closure of the X-2.31B unit. This was accomplished in concert with the revision of the COS.

In October and November 199(), several brainstorming sessions were held at ORNL with research staff of diverse backgrounds and experience in soil and groundwater remediation technologies. These meetings led to development of a "candidate list" including several technologies judged to be appropriate for further consideration (Table 1.1). However, before implementing one or more technologies for full-scale remediation of the X-231B unit, the ORNL team concluded that a Technology Demonstiation Project must be completed. The principal goal of this project was to select and successfully demonstrate one or more technologies for effective treatment of the contaminated soils associated with the X-23IB unit at PORTS. 
The project was divided into two major phases. Phase 1 involved a technology evaluation and screening process. The objectives of this phase were to define the problem domain and performance criteria; delineate the constraints affecting implementation of the technology demonstration; and identify, evaluate, and recommend technologies judged to be capable of removing or immobilizing VOCs in the contaminated soils at the site. Phase 1 was to be accomplished between November 1990 and February 1991.

The second phase (i.e., Phase 2) was to involve field demonstration, testing and evaluation of the technology(s) selected during Phase 1. The objectives of this phase were to design the demonstration, procure any vendor technologies, address/gain plans and permits, and implement and evaluate the performance of the technology(s). Phase 2 was to be accomplished over a 14month period following completion and acceptance of the Phase 1 study.

This report presents the methods, results, and conclusions of the technology evaluation and screening portion of the project. The information reported in this document was prepared between December 1990 and February 1991. In March 1991, a draft report was issued for internal use to support development of the Phase 2 demonstration effort. The report contained herein is a final version of the March 1991 draft report. The narrative was revised based on editorial review and comment. Considerable information contained in the draft report and used in the screening process (e.g., process schematics and photographs, vendor supplied process information) has been omitted from this final report. This was done to simplify publication and to comply with requests by many of the vendors surveyed, that information provided by them not be published. 


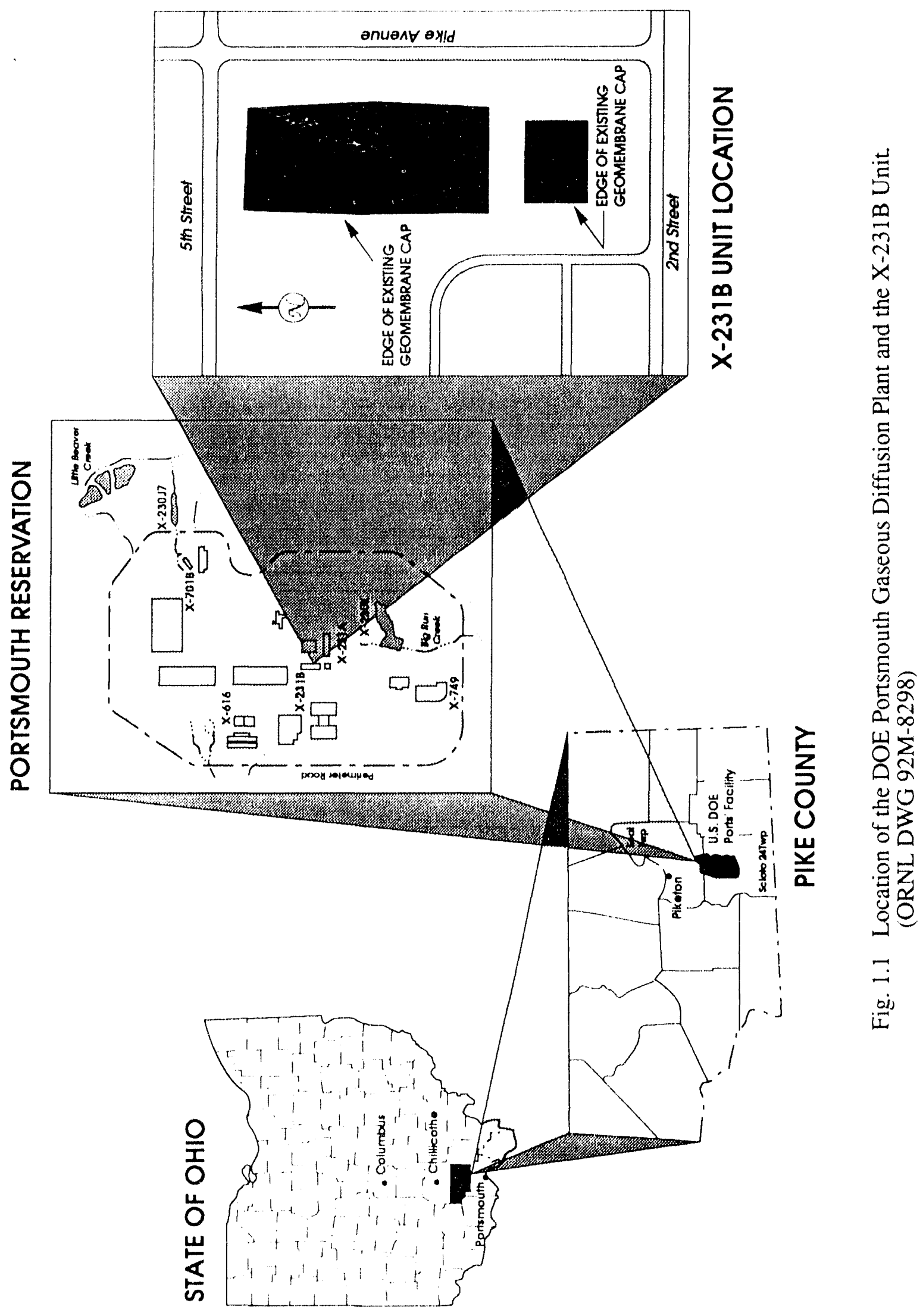




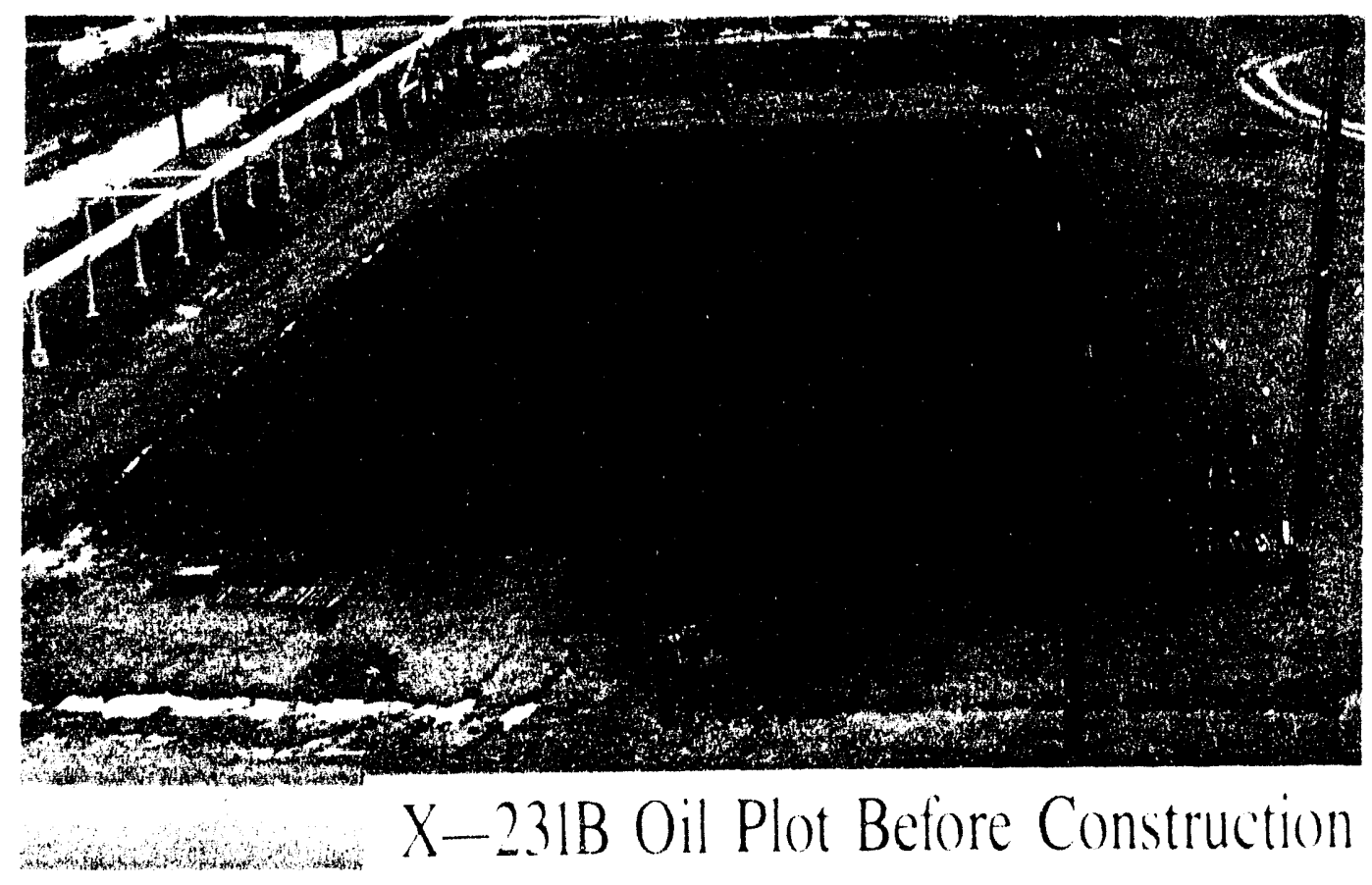

Fig. 1.2. Photograph of X-231B oil biodegradation unit before the interim cap was placed in 1987. (ORNL Photo 11772-91) 
Table 1.1. List of candidate technologies for demonstration at the X-231B oil biodegradation unit at PORTS. $\underline{\text { a }}$

Medium Technology options $\underline{b} \quad$ Comments

Soil $\underline{c} \quad$ In situ mixing and hot-air/ steam stripping

Complete technology developed and prototype in use. Demonstration needed at site with conditions like PORTS

In situ (ex situ) mixing with hydrogen peroxide

stripping/oxidation

Deep mixing technology available and aboveground hydrogen peroxide treatment demonstrated. In situ hydrogen peroxide treatment not demonstrated

In situ solidification/ stabilization

Complete technology available from several vendors but demonstration in silty clay soils with VOCs needed

In situ radiofrequency heating

Technology developed and available but not in use. Demonstration needed in silty clay materials

In situ jet mixing and slurry reactor Component technologies available but process not demonstrated in situ

Excavation with on-site low temperature thermal desorption

Technology available and in use. Demonstration in conditions similar to PORTS is necessary

Ground- Inert gas stripping with water d catalytic combustion

Component technologies available but process not demonstrated

Air stripping and gasphase biotreatment

Technology under development and being readied for demonstration

a Current technology options were developed based on preliminary knowledge of site conditions, contaminant levels, and performance objectives.

b The order of presentation in this table does not indicate technology priority or ranking.

c Demonstration of one or two soil treatment technologies could be conducted on a test site (e.g., $25 \mathrm{ft}$ by 40 ) ft size range) within the X-231B unit and would treat the Minford silty clay deposit from the ground surface 10 a depth of approximately to $25 \mathrm{ft}$. Soil treatment would attempt to reduce volatile organic compounds by approximately $90 \%$ or to a performance level to be cooperatively established.

d Demonstration of one or two groundwater treatment technologies could be conducted on a sidestream derived from the planned interim groundwater pump and treat system. Groundwater treatment would attempt to effectively decrease volatile organic compounds by approximately $90 \%$ or to a performance level to be cooperatively established. 


\subsection{SYNOPSIS OF EXISTING CONDITIONS}

Conditions at and around the $\mathrm{X}-231 \mathrm{~B}$ unit have been characterized as part of several investigations over the past 8 years. A synopsis of the existing conditions at the site is provided below; further details may be found in other published reports $[1-4]$.

\subsection{SITE HISTORY AND STATUS}

The X-231B oil biodegradation unit was used $\sim 1976$ to 1983 for the land treatment and disposal of waste oils and degreasing solvents. In late 1987, the U.S. Department of Energy (DOE) had a temporary cover placed over the then-inactive waste treatment unit. This impermeable, single-layer (36-mil Dynaloy) cap was constructed to prevent precipitation impact, infiltration, or runoff at the site. The cap was laid with a $1 \%$ slope to the southeast to divert precipitation runoff to the storm drains.

Access to the site is controlled, as it is within the secure portion of the plant. A perimeter fence and 24-h security patrols limit access to trained and authorized personnel only. The site remains inactive and is currently being formally closed per RCRA requirements. It is also a designated solid waste management unit as part of an ongoing RCRA RFI/CMS project.

\subsection{SITE PHYSICAL CHARACTERISTICS}

\subsubsection{Setting}

The X-231B unit at PORTS consists of two separate plots (Fig. 2.1). The larger, northern plot is approximately $265 \mathrm{ft}$ long by $110 \mathrm{ft}$ wide. The smaller, southern plot is $100 \mathrm{ft}$ long by $70 \mathrm{ft}$ wide. The overall site and the immediate vicinity is level.

There are underground and overhead utility lines around and within X-231B (Fig. 2.1). These utilities were reportedly installed during plant construction and include: storm and sanitary sewers, water supply lines, cooling tower supply and return lines, air and steam lines, and electrical lines. These lines present difficulties to some remediation schemes. However, there are plans to relocate the utilities prior to conduct of any soil remediation activities.

\subsubsection{Soil and Geology}

The site of $\mathrm{X}-231 \mathrm{~B}$ is characterized by a thin mantle of unconsolidated deposits, known as the Teays Formation, overlying Mississippian bedrock (Fig. 2.2). The unconsolidated deposits consist of fluviolacustrine clay and silt (Minford Member) underlain by a thin layer of fluvial sand and gravel (Gallia Member). The Minford is further subdivided into an upper clay and lower silt. The upper clay is generally reddish brown in color and is about $15 \mathrm{ft}$ thick. The lower portion of the Minford is a yellow-brown silt approximately $10 \mathrm{ft}$ thick.

The Gallia member underlies the Minford at a depth of $\sim 25 \mathrm{ft}$. It is a very poorly sorted, sand and gravel with significant amounts of silt and clay $(\sim 15$ to $52 \%)$. It is a red-brown, clayey sand (SC) to a silty gravel (GM) or clayey gravel (GC). It is present under the X-231B site, but it is less than $4 \mathrm{ft}$ thick. It is discontinuous across the PORTS site as a whole and where present, it usually does not exceed $5 \mathrm{ft}$ in thickness. 


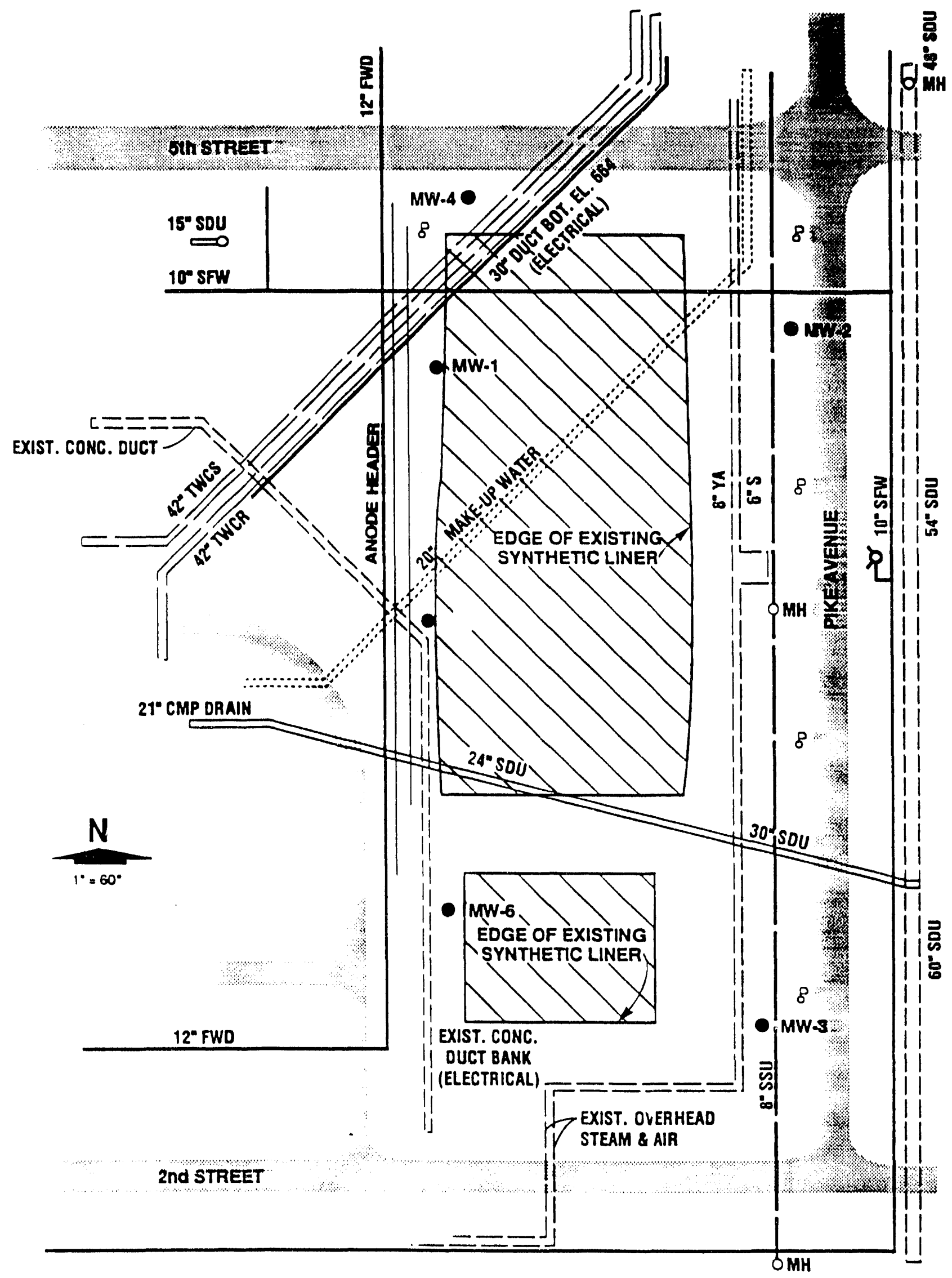

Fig. 2.1. Map of the X-231B unit indicating its areal extent and the location of various utilities. (Source: Morrison and Knudsen, 1990 [2]) 


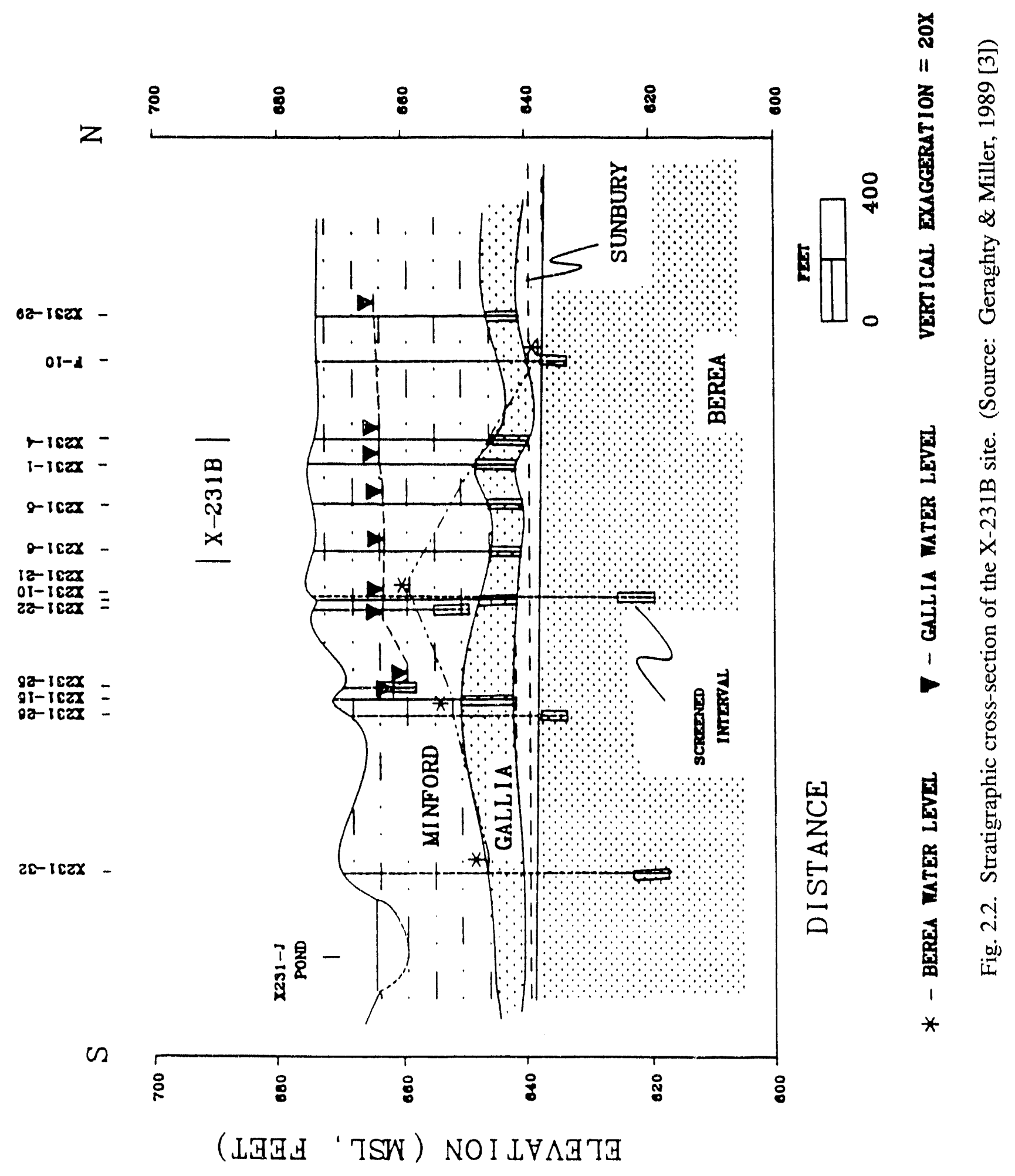


The Mississippian bedrock sequence exists below the shallow unconsolidated deposits and has a regional dip of about $30 \mathrm{ft}$ per mile to the east. The bedrock surface at X-231B is generally flat with a slight to moderate slop to the southeast. The shallowest bedrock unit is the Sunbury Shale. The Sunbury is slightly fractured and is 10 to $12 \mathrm{ft}$ thick. Directly under the Sunbury is the Berea, a hard, thick-bedded, fine-grained sandstone averaging $30 \mathrm{ft}$ in thickness. The upper surface of the Berea dips gently to the southeast.

\subsubsection{Hyd rogeology}

Groundwater underneath the X-231B unit occurs in two aquifer systems: the Minford/Gallia members and the Berea sandstone (Fig. 2.2). The depth to the water table underneath the site is $\sim 10 \mathrm{ft}$. The hydraulic conductivities of all the shallow units are low. Laboratory measurements revealed a saturated hydraulic conductivity (Ksat) of only $0.00023 \mathrm{ft} / \mathrm{d}$ for the Minford clay and $0.0043 \mathrm{ft} / \mathrm{d}$ for the Minford silt. Field pumping tests yielded a substantially higher mean Ksat for the Gallia deposit of $7.1 \mathrm{ft} / \mathrm{d}$. The lower portion of the Minford is in hydraulic continuity with the Gallia [3].

The permeability of the Sunbury Shale is believed to be very low. Although thin and slightly fractured, the Sunbury may hydraulically isolate the underlying Berea from the overlying unconsolidated aquifer (i.e., Minford/Gallia).

Thirty-six groundwater monitoring wells have been installed in the vicinity of the X-231B unit over the past few years. Twenty-five wells have been installed and screened within the Gallia deposit, but only three wells have been screened in the overlying Minford. Eight wells penetrate into the underlying bedrock (i.e., Sunbury or Berea). Horizontal hydraulic gradients in all three units at X-231B (i.e., Minford, Gallia, and Berea) indicate a southeasterly flow. The hydraulic gradients are low, however.

\subsection{SITE CONTAMINATION CHARACTERISTICS}

\subsubsection{Soil Contamination}

Several field investigations have been conducted within and around the X-231B Unit during the past 5 years [2-4]. The first study was conducted by Goodyear Atomic Corporation in January 1986. This study was limited to hand auger borings to $\sim 3-\mathrm{ft}$ depth at 12 locations within the $\mathrm{X}$ 231B unit boundaries. High levels of VOCs were detected in the samples. PCBs were also detected, but only in 6 of 12 borings and at concentrations of only 1 to $7 \mathrm{mg} / \mathrm{kg}$ (ppm).

The second investigation was conducted by Geraghty \& Miller, Inc., in April 1986. This study consisted of hand auger borings in 14 locations within the unit. Soil samples were collected at depth zones of 0 to 2,4 to 6 , and 8 to $10 \mathrm{ft}$. This study found a maximum VOC concentration of $12,000 \mu \mathrm{g} / \mathrm{kg}(\mathrm{ppb})$ in the 0 to $2 \mathrm{ft}$ depth zone and a general trend of declining VOC concentrations with depth. Trichloroethene (TCE) and trichloroethane (TCA) were the primary contaminants.

A third study was conducted by IEP, Inc. in 1986 [2]. Soil samples collected from ten, 10-ft deep boreholes were analyzed for RCRA Appendix VIII contaminants. Five samples were selected for this analysis based on those with the highest field readings for VOCs. Four of the five samples were from $3.5 \mathrm{ft}$ deep and one was from $7.0 \mathrm{ft}$. Of the seven VOCs analyzed as part of the Appendix VIII list, TCA and TCE were present at the highest concentrations $(8,900$ and 7,200 $\mathrm{mg} / \mathrm{kg}$, respectively). However, the concentrations varied widely among borings. Other VOCs detected included, methylene chloride, 1,1-dichloroethene, tetrachloroethene, chloroform, and freon. Analyses for pesticides and heavy metals revealed nondetectable or very low 
concentrations. Total alpha and total beta radiation was below $100 \mathrm{cpm}$ except in two samples which measured $\sim 100$ to $200 \mathrm{cpm}(\sim 2200 \mathrm{cpm}=1 \mathrm{nCi})$.

The fourth and most definitive study was conducted by ASI from June 1987 through January 1988 $[3,4]$. This study consisted of 16 test borings drilled to the Sunbury Shale at a depth of $30 \mathrm{ft}$ Soil samples were collected at selected intervals and analyzed for VOCs, metals, herbicides and PCBs, and radioactivity (Table 2.1 ). The results of this study showed general contamination of the soil by VOCs, with TCE and TCA being the primary contaminants. Soil concentrations ranged from nondetectable to $17,000 \mu \mathrm{g} / \mathrm{kg}$ for TCA and nondetectable to 13,000 for TCE. Acetone and Freon113 were also prevalent at appreciable concentrations. The highest VOC concentrations were typically found at or just above the groundwater table (Fig. 2.1). Metal contamination was generally low and within probable background or normal soil levels. No pesticides, herbicides or PCBs were detected in this study. Total alpha activities were generally low. Only 12 of 69 samples exhibited alpha levels above the detection limit of $10 \mathrm{nCi} / \mathrm{kg}$. This contamination was largely confined to the top $12 \mathrm{ft}$ of soil. This compared with a reported background level of 3 to 6 $\mathrm{nCi} / \mathrm{kg}$. Total beta activities were measured in all boreholes, but levels were normally below 30 $\mathrm{nCi} / \mathrm{kg}$. Total uranium concentrations averaged $3 \mathrm{mg} / \mathrm{kg}$.

\subsubsection{Groundwater Contamination}

IEP. Inc., sampled three groundwater monitoring wells located near X-231B, and samples were analyzed for RCRA Appendix IX contaminants [2]. Wells MW-1, MW-5, and MW-6 were selected for this sampling and analyses based on previous work, which showed them to be within the area of highest contaminant concentrations around X-231B. These analyses revealed that all three wells were contaminated with TCE $(308$ to $696 \mu \mathrm{g} / \mathrm{L})$, TCA $(62$ to $3910 \mu \mathrm{g} / \mathrm{L})$ and 1,1 dichloroethene (DCE) $(67$ to $924 \mu \mathrm{g} / \mathrm{L})$ at levels well above federal drinking water standards (see Table 2.2). Lower levels of seven other organics were found in some of the wells. Metals were detected, but concentrations were within drinking water standards, except for of iron, which was present at high concentrations.

Additional analyses of groundwater samples from monitoring wells into the Gallia deposit around X-231B identified 12 VOCs above detection limits. Six VOCs were widespread: TCE, TCA, 1,1-dichloroethane (DCA), chloroform, 1,1-DCE, and 1,2-dichloroethene (1,2-DCE) (Table 2.2). VOC concentrations were generally in the 100 to $1000 \mu \mathrm{g} / \mathrm{L}$ range. A site map depicting the extent of the groundwater plume, as illustrated by an isoconcentration contour map for TCE in the Gallia, is presented in Fig. 2.4. This indicates the plume has spread $\sim 750 \mathrm{ft}$ southeast of the southeast edge of $\mathrm{X}-231 \mathrm{~B}$. 
Table 2.1. Summary of soil contamination levels with depth below X-231B. (Source: Advanced Sciences, Inc., 1988 [4])

\begin{tabular}{|c|c|c|c|c|c|c|}
\hline \multirow[b]{2}{*}{ Constituent } & \multicolumn{6}{|c|}{ Depth below ground surface $(\mathrm{ft})$} \\
\hline & $0-2$ & $8-10$ & $12-14$ & $16-18$ & $20-22$ & $.24-26$ \\
\hline $\begin{array}{l}\text { Volatile Organics, } \mu g / k g \\
\text { 1,1-Dichloroethane [50] a } \\
\text { 1,2-Dichloroethane [50] } \\
\text { 1,2-Trans-dichloroethene [50] } \\
\text { 1,1-Dichloroethene [50] } \\
\text { Methylene chloride }[50] \\
\text { 1,1,1-Trichloroethane [50] } \\
\text { 1,1,2-Trichloroethane [50] } \\
\text { Trichloroethene [50] } \\
\text { Acetone [50] } \\
\text { Trichlorofluoromethane [50] } \\
\text { Freon } 113 \text { [50] } \\
\text { Chloroform [50] }\end{array}$ & $\begin{array}{l}\text { nd } \underline{b} \\
\text { nd } \\
\text { nd } \\
\text { nd } \\
\text { nd-160 } \\
\text { nd-200 } \\
\text { nd- } \\
\text { nd-120 } \\
\text { nd-23000 } \\
\text { nd } \\
\text { nd-2200 } \\
\text { nd }\end{array}$ & $\begin{array}{l}\text { nd } \\
\text { nd } \\
\text { nd } \\
\text { nd- } 83 \\
\text { nd } \\
\text { nd- } 10000 \\
\text { nd } \\
\text { nd- } 7300 \\
\text { nd-6200 } \\
\text { nd } \\
\text { nd- } 11000 \\
\text { nd }\end{array}$ & $\begin{array}{l}\text { nd } \\
\text { nd } \\
\text { nd } \\
\text { nd-1800 } \\
\text { nd-500 } \\
\text { nd-4100 } \\
\text { nd-130 } \\
\text { nd-5300 } \\
\text { nd-3800 } \\
\text { nd } \\
\text { nd-7000 } \\
\text { nd-580 }\end{array}$ & $\begin{array}{l}\text { nd }-150 \\
\text { nd } \\
\text { nd } \\
\text { nd- } 410 \\
\text { nd-55 } \\
\text { nd } 5000 \\
\text { nd- } 140 \\
\text { nd }-4800 \\
\text { nd- } 12000 \\
\text { nd } \\
\text { nd } 5900 \\
\text { nd. } 57\end{array}$ & $\begin{array}{l}\text { nd- } 120 \\
\text { nd } \\
\text { nd } \\
\text { nd- } 5500 \\
\text { nd- } 160 \\
\text { nd- } 17000 \\
\text { nd- } 140 \\
\text { nd- } 13000 \\
\text { nd- } 1000 \\
\text { nd } \\
\text { nd- } 4900 \\
\text { nd }-240\end{array}$ & $\begin{array}{l}\text { nd-240 } \\
\text { nd } \\
\text { nd } \\
\text { nd-230 } \\
\text { nd } \\
\text { nd-810 } \\
\text { nd } \\
\text { nd- } 4500 \\
\text { nd- } 2900 \\
\text { nd } \\
\text { nd-2600 } \\
\text { nd- } 110\end{array}$ \\
\hline \multicolumn{7}{|l|}{$\begin{array}{l}\text { Metals, Herbicides, and } \\
\text { PCBs, } m g / k g\end{array}$} \\
\hline Arsenic $[10]$ & nd & nd & $\mathcal{S}$ & nd & $\underline{c}$ & nd \\
\hline Barium & $38-86$ & $24-51$ & $\mathrm{c}$ & $19-44$ & $\mathfrak{c}$ & $17-24$ \\
\hline Cadmium [01] & nd & nd & $\mathfrak{s}$ & nd & $\underline{\mathbf{c}}$ & nd \\
\hline Chromium & $14-31$ & $9-20$ & $\mathcal{s}$ & $7-14$ & $\underline{c}$ & $9-18$ \\
\hline Lead & $20-28$ & $16-23$ & $\mathfrak{s}$ & $10-18$ & c & $13-20$ \\
\hline Mercury $\quad[0.02]$ & nd -0.84 & nd -0.04 & $\boldsymbol{s}$ & nd & $\underline{c}$ & nd \\
\hline Nickel & $8-18$ & $7-20$ & $\underline{c}$ & $9-15$ & $\underline{c}$ & $13-21$ \\
\hline Beryllium $[01]$ & nd & nd & $\underline{c}$ & nd & $\mathbf{c}$ & nd \\
\hline $2,4-\mathrm{D}$ & nd & nd & $\mathfrak{c}$ & nd & $\underline{\mathrm{c}}$ & nd \\
\hline 2,4,5-TP (Silvex) & nd & nd & $\mathcal{c}$ & nd & $\underline{\mathrm{c}}$ & nd \\
\hline Polychorinated biphenyls & nd & nd & $\underline{c}$ & nd & $\underline{\mathcal{C}}$ & nd \\
\hline $\begin{array}{l}\text { Radioactivity } \\
\text { Total Alpha, nCi/kg [10] } \\
\text { Total Beta, nCi/kg [10] } \\
\text { Total Uranium, } \mathrm{mg} / \mathrm{kg} \\
\text { Technetium, nCi/kg [2] }\end{array}$ & $\begin{array}{l}\text { nd }-150 \\
\text { nd }-200 \\
2-150 \\
\text { nd } 380\end{array}$ & $\begin{array}{l}\text { nd } \\
\text { nd- } 22 \\
2-8\end{array}$ & $\begin{array}{l}\text { nd } \\
\text { nd-31 } \\
1-3\end{array}$ & $\begin{array}{l}\text { nd } \\
\text { nd-33 } \\
2-3\end{array}$ & $\begin{array}{l}\text { nd } \\
\text { nd-34 } \\
2-3\end{array}$ & $\begin{array}{l}\text { nd } \\
\text { nd-34 } \\
2-3\end{array}$ \\
\hline
\end{tabular}

a The number in brackets is the method detection limit.

$\underline{b}$ "nd" indicates constituent not detected at detection limit shown.

$\underline{c}$ indicates analyses not performed. 
(4) บ입əㅋ

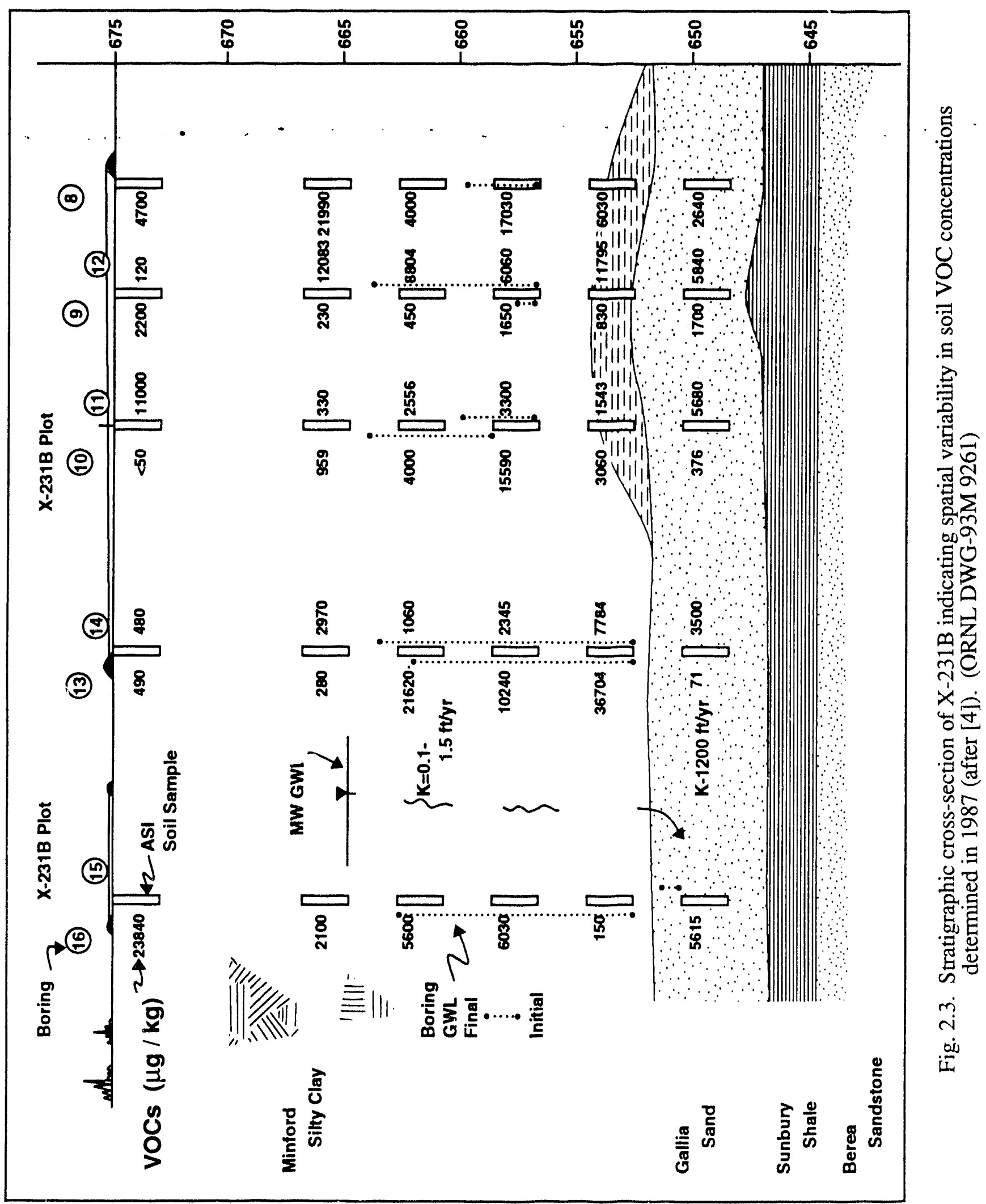


Table 2.2. Summary of groundwater contaminant concentracions at X-231B. (Source: Morrison Knudsen, 1990 [2])

\begin{tabular}{|c|c|c|c|c|c|}
\hline \multirow[b]{2}{*}{ Constituent $\underline{\mathbf{a}}$} & \multirow[b]{2}{*}{ Units } & \multicolumn{3}{|c|}{ Concentrations $\underline{b}$} & \multirow[b]{2}{*}{ Comments } \\
\hline & & Average $\underline{c}$ & Min. & Max. & \\
\hline Trichloroethene & $\mu \mathrm{g} / \mathrm{L}$ & $\begin{array}{l}464.0 \\
\{5\} \stackrel{d}{d}\end{array}$ & 180 & 1400 & Detected in every well \\
\hline 1,1-Dichloroethane & $\mu \mathrm{g} / \mathrm{L}$ & $\begin{array}{c}9.4 \\
\{-\}\end{array}$ & 5 & 27 & $\begin{array}{l}\text { Detected only in wells MW1, } \\
\text { MW5, MW6 and MW10 }\end{array}$ \\
\hline 1,1-Dichloroethene & $\mu \mathrm{g} / \mathrm{L}$ & $\begin{array}{l}88.3 \\
\{7\}\end{array}$ & 5 & 320 & $\begin{array}{l}\text { Not detected in wells MW2 } \\
\text { MW4 and MW17 }\end{array}$ \\
\hline 1,2-Dichloroethene & $\mu \mathrm{g} / \mathrm{L}$ & $\begin{array}{c}9.6 \\
\{70,100\}\end{array}$ & 5 & 26 & $\begin{array}{l}\text { Detected only in wells MW5, } \\
\text { MW6, MW10 and MW17 }\end{array}$ \\
\hline 1,1,1-Trichloroethane & $\mu \mathrm{g} / \mathrm{L}$ & $\begin{array}{l}188.0 \\
\{200\}\end{array}$ & 5 & 790 & $\begin{array}{l}\text { Not detected in wells MW2 } \\
\text { MW4 and MW17 }\end{array}$ \\
\hline Chloroform & $\mu \mathrm{g} / \mathrm{L}$ & $\begin{array}{l}17.6 \\
\{-\}\end{array}$ & 5 & 110 & $\begin{array}{l}\text { Detcoted only in wells MW1 } \\
\text { and MW5 }\end{array}$ \\
\hline Aluminum & $\mathrm{mg} / \mathrm{L}$ & $\begin{array}{l}4.1 \\
\{-\}\end{array}$ & 1.4 & 8.7 & Not detected in well MW6 \\
\hline Iron & $\mathrm{mg} / \mathrm{L}$ & $\{300\}$ & 3.3 & 23.6 & $\underline{\mathrm{e}}$ \\
\hline Manganese & $\mathrm{mg} / \mathrm{L}$ & $\begin{array}{l}0.37 \\
\{50\}\end{array}$ & 0.27 & 0.44 & $\underline{\mathrm{e}}$ \\
\hline Alpha & $\mathrm{pCi} / \mathrm{L}$ & $\begin{array}{l}35.2 \\
\{15\}\end{array}$ & 30 & 76 & $\begin{array}{l}\text { Detected only in wells MW1 } \\
\text { and MW4 (Qualitative data) }\end{array}$ \\
\hline Beta & $\mathrm{pCi} / \mathrm{L}$ & $\begin{array}{c}64.2 \\
\{4 \mathrm{mrem} / \mathrm{yr}\}\end{array}$ & 60 & 80 & $\begin{array}{l}\text { Detected only in wells MW4 } \\
\text { and MW6 (Quantitative data) }\end{array}$ \\
\hline Uranium & $\mu \mathrm{g} / \mathrm{L}$ & $\begin{array}{l}12.9 \\
\{-\}\end{array}$ & 1 & 39 & $\begin{array}{l}\text { Not detected in wells MW6 } \\
\text { and MW17 }\end{array}$ \\
\hline Technetium, beta & $\mathrm{pCi} / \mathrm{L}$ & $\begin{array}{c}41.1 \\
\{4 \mathrm{mrem} / \mathrm{yr}\} \\
\end{array}$ & 25 & 88 & $\begin{array}{l}\text { Detected only in wells MW1, } \\
\text { MW2, MW4 and MW6 }\end{array}$ \\
\hline
\end{tabular}

a The only constituents shown are those which were detected in more than one well.

$\underline{b}$ The analyses provided in this table were performed in November-December 1988.

c The average concentrations were computed using the individual concentrations measured at all wells divided by the number of wells. For samples with no detects, the method detection limit was used in the computation and is shown as the minimum concentration.

d The numbers in brackets are equal to Federal Maximum Contaminant Limits or Goals for drinking water.

e The concentrations of aluminum, iron and, manganese were measured in wells MW1, MW5 and MW6 in April 1989. 


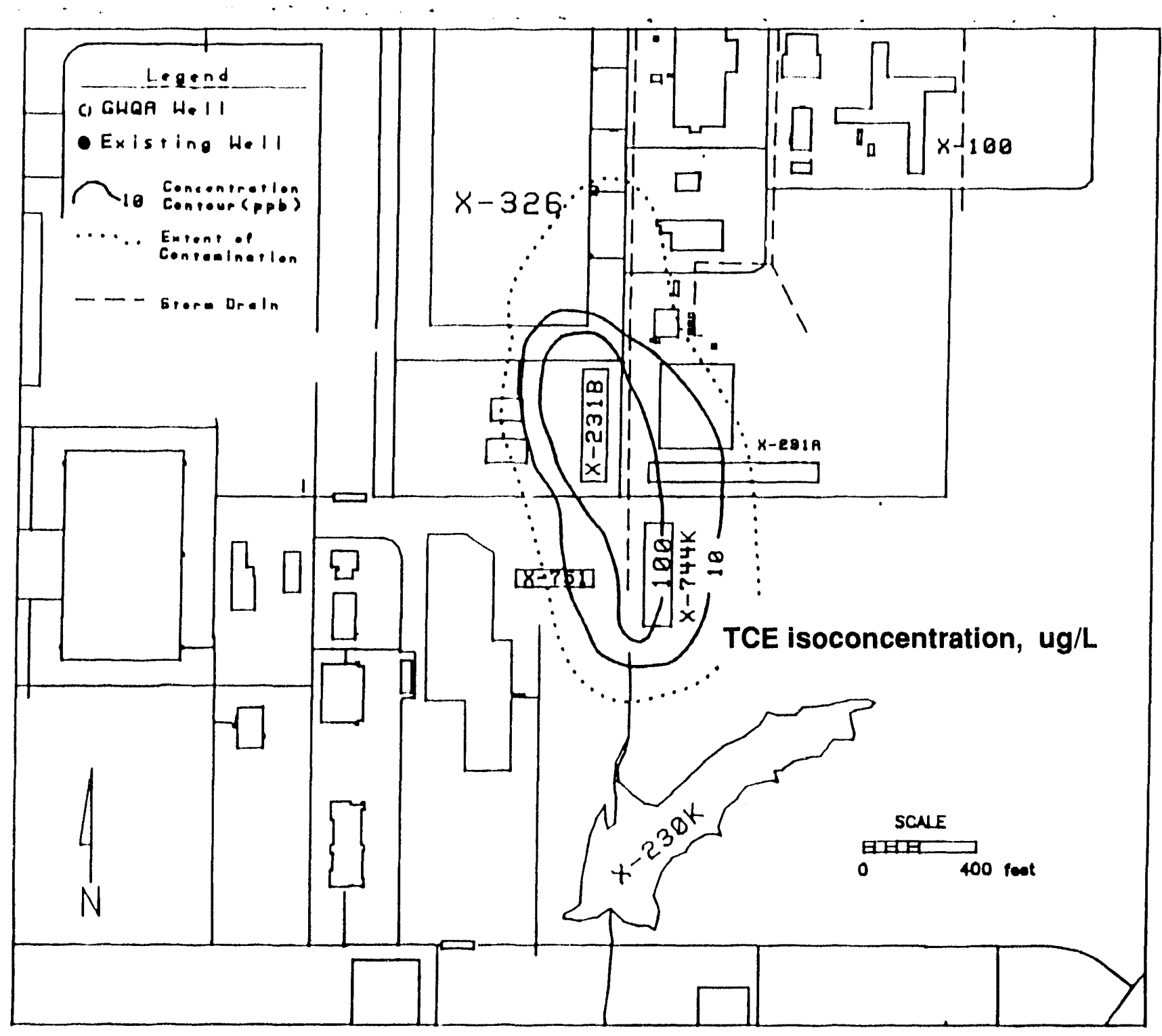

Fig. 2.4. Map of X-231B indicating extent of groundwater contamination by TCE in the Gallia deposit under and around X-231B. (Source: Geraghty \& Miller, Inc., 1989 [3]) 


\subsection{PROBLEM DEFINITION AND PERFORMANCE CRITERIA}

\subsection{INTRODUCTION}

To begin identification and evaluation of potential soil remediation technologies, it was necessary to explicitly define the soil contamination problem and the remediation performance criteria. Because of the compressed project timetable, it was necessary to accomplish this early in the project without having a complete data base and without having interacted with all parties who might ultimately have decision-making authority in this matter.

\subsection{MATERIALS AND METHODS}

Problem definition and performance criteria were established as follows. The methods and results of prior field investigations were reviewed and analyzed by members of the project team to delineate the existing conditions (Sect. 2). A review was made of the closure methods considered for the X-231B unit as well as those accepted by the OEPA regulating community. This implicitly established a problem domain and performance criteria for the soils at the Unit. There were also explicit, existing regulatory requirements and commitments made by DOE to OEPA concerning the treatment efficiency that would be achieved (i.e., 70 to $95 \%$ reduction in soil VOCs). Finally, consideration was given to the technical implications of the problem definition and performance criteria for the $\mathrm{X}-231 \mathrm{~B}$ unit closure and long-term groundwater monitoring and management.

It was recognized that the problem definition and performance criteria could change in the latter stages of the project, based on future project modeling and assessment efforts as well as the outcome of future interactions with the regulatory community [i.e., OEPA and U.S. Environmental Protection Agency (EPA)l.

\subsection{RESULTS AND DISCUSSION}

\subsubsection{Problem Domain}

The problem domain defined for purposes of this phase of the project is illustrated in Fig. 3.1 and is described below. The problem domain includes the $25 \mathrm{ft}$ of the Minford deposit from the ground surface to the top of the Gallia deposit. This deposit includes fine-textured soils with high water contents and low permeabilities. Horizontally, the problem domain extends to the unit boundaries.

VOCs are the primary contaminants of concern based on the results of four studies from 1986 to 1987 (total of 33 borings) and the characterization study completed by ORNL in 1990). The VOCs found to be most prevalent and at the highest concentrations are TCE and TCA. Also detected have been chloroform, 1,1-dichloroethane, 1,2-dichloroethane, 1,2-trans-dichloroethene, 1,1dichloroethene, tetrachloroethylene, methylene chloride (MC), 1,1,2-trichloroethane, acetone, trichlorofluoromethane, and freon 113.

\subsubsection{Performance Assumptions for Technology Evaluation and Screening}

Process performance criteria are proposed with total VOCs as the target parameter for evaluation. For the purposes of this work, VOCs include about 35 compounds on the EPA volatile hazardous substance list. Although other potential contaminants are present within the problem domain (see 


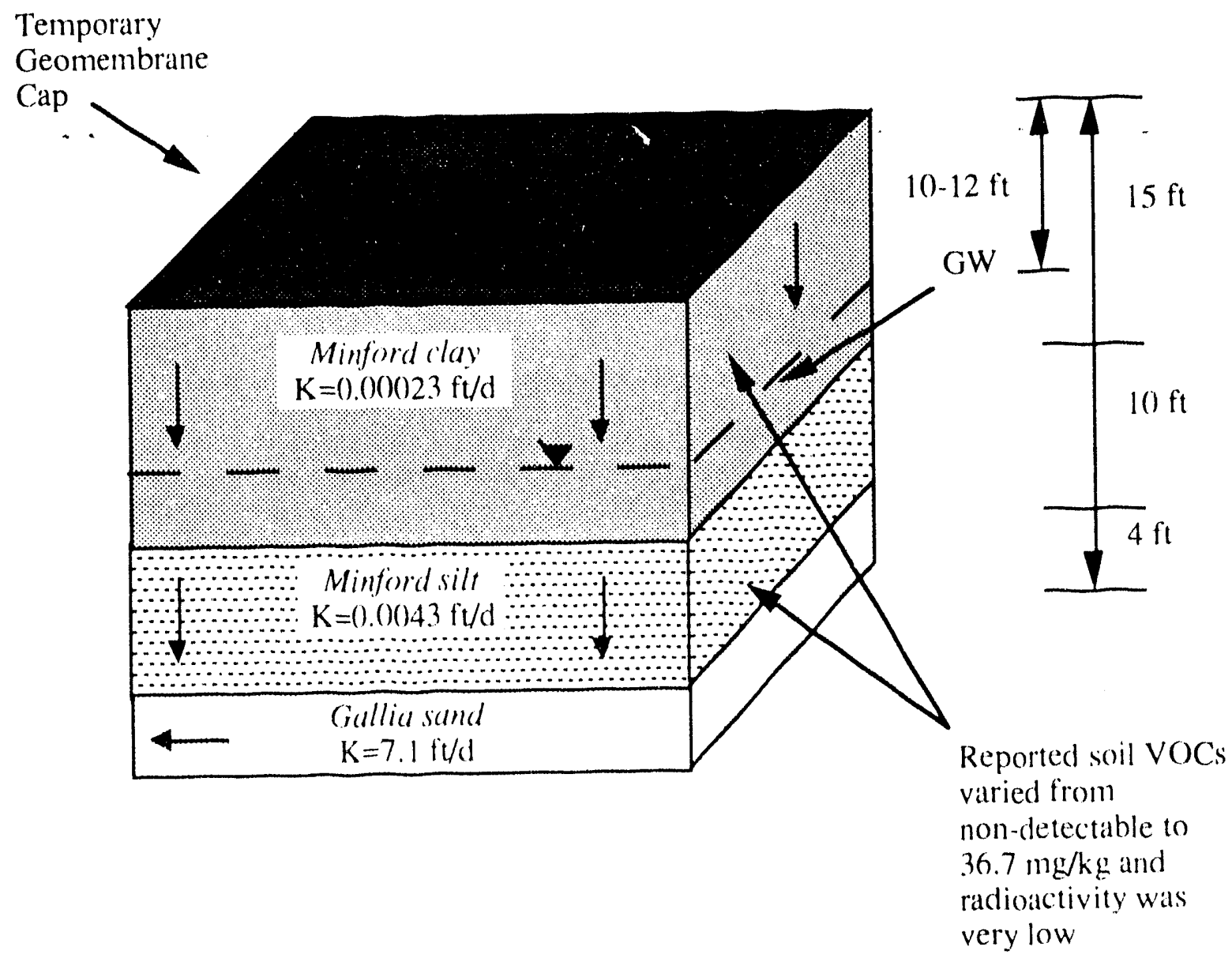

Fig. 3.1. Schematic of the contaminated soil problem domain at the X-231B site. 
Sect. 2), including low levels of radioactivity and metals, the VOCs were selected as targets based on their presence in the groundwater above federal drinking water standards (see Table 2.2) and the requirements of OEPA to address this soil contamination as part of the closure of this unit.

For the purposes of this technology evaluation and screening, the technology(s) recommended for implementation should be judged capable of achieving the following minimum performance criteria:

1. Remove or destroy the soil VOCs so that the residual total VOC concentration in the soil $<1 \mathrm{mg} / \mathrm{kg} \quad(\sim 90 \%$ reduction from mean total VOC concentration measured in 1987).

or,

2. Immobilize the soil VOCs so the concentrations in the leachate from an EPA Toxicity Characteristic Leaching Procedure (TCLP) test are below the toxicity characteristic thresholds (e.g., trichloroethylene $=0.5 \mathrm{mg} / \mathrm{L}$ and 1,1 dichloroethylene $=0.7 \mathrm{mg} / \mathrm{L})$.

These performance criteria were judged to be consistent with the regulatory commitments made previously by DOE and Energy Systems and with cleanup criteria used in similar situations. Moreover, it was believed by the project team that one or more of the candidate technologies could achieve the levels shown.

\subsubsection{Performance Criteria Development During Technology Demonstration}

As part of the Phase 2 technology demonstration, testing, and evaluation, it was envisioned that performance criteria would be explicitly established and monitoring would be conducted to enable relevant performance assessments. The results of the Phase 2 effort would thus provide important information for establishment of performance criteria for full-scale closure of the X-231B unit. 
$-$

. . 


\subsection{SITE CHARACTERIZATION}

\subsection{INTRODUC'TION}

After reviewing the documents describing the physical conditions at the site and the nature and extent of soil contamination, members of the project team determined that additional site characterization" work was needed. The goal of this work was to verify current soil VOC contamination levels and to determine soil physical/chemical/biological properties relevant to soil remediation technology application and performance. Samples were also collected for a risk assessment effort being conducted by other ORNL staff in parallel to the technology demonstration work.

\subsection{MATERIALS AND METHODS}

\subsubsection{Drilling and Soil Sampling}

Site characterization work was conducted during December 17-20, 199(). Subsurface soil samples were collected at three locations $(\mathrm{SBO}) 1=$ southwest, $\mathrm{SB}(2)=$ center, and $\mathrm{SB}()_{3} 3=$ northeast) within the larger northern plot of X-231B (Fig. 4.1). The subcontractor responsible for conduct of the RFI (i.e., Geraghty \& Miller, Inc.) was contracted to assist with this work. The procedures used were those approved for the RFI [5] unless otherwise indicated.

A truck-mounted drill rig (CME-45) was used for drilling and soil sampling. Soil samples were collected at selected depths from the ground surface to $\sim 24$ - $\mathrm{ft}$ depth using a split-barrel sampler and a 3.25 in. (ID) hollow-stem auger. The six sampling intervals were () to 2,4 to 6,6 to 8,10 to 12 , 16 to 18 , and 22 to $24 \mathrm{ft}$. The $6-$ to 8 - $\mathrm{ft}$ and $16-$ to 18 - $\mathrm{ft}$ intervals were selected for acquisition of soil samples for the technology demonstration. These two intervals were selected to enable characterization of the upper and lower units of the Minford Member, above and below the groundwater table, respectively. The other four intervals were used to collect samples for the risk analysis effort.

The technology demonstration soil samples were collected with a 3 -in. dia. split-barrel sampler fitted with a series of stainless steel sleeves. Each 2-ft-long sampler contained a 12-in., 4-in., 4in., and 12-in. sleeve, in that order.

The borehole locations were marked, and precautions were taken to prevent any damage to the geomembrane cap over the X-231B unit (Fig. 4.1). This was done by laying plastic on top of the cap, covering this with a layer of straw and then laying $3 / 4$-in. thick plywood sheets down. The drill rig was driven across this surface and set up at each borehole location. A small hole was carefully cut through the geomembrane cap to facilitate the boring process. After augering to the desired depth and driving the sampler, the sampler was removed from the boring and placed on clean aluminum foil on a work table near the borehole location. The sampler was opened and the bottom 4-in. sleeve was then removed and subsampled as described in the following section.

All drilling equipment was decontaminated using a steam cleaner before drilling the first borehole and between each of the subsequent boreholes. The split-barrel samplers were similarly cleaned before and between each sampling interval. During the drilling process, no drilling fluids |i.e., air, water, or "mud" (mineral or organic polymer)] were used. 


\section{LEGEND}

(4) ORNL SOIL BORING LOCATION

[ ASI SOIL BORING LOCATION

- gat soll boring location

$\triangle$ GERAGHTY \& MILLER SOIL BORING LOCATION

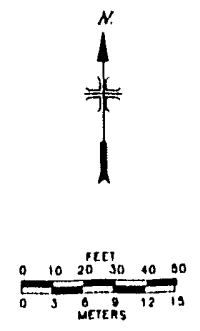

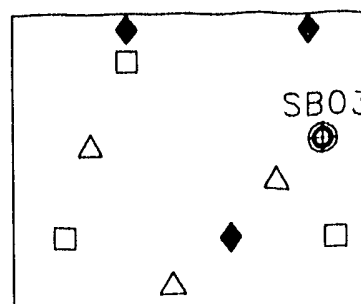
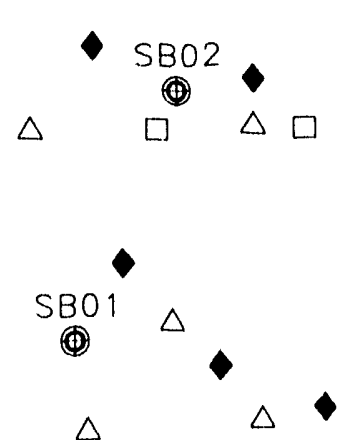

$\square$

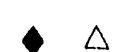

$\square$

岁
3
$\sum$
4
4
6
0
2
3
0
0
01
0
1
0
0
0
4

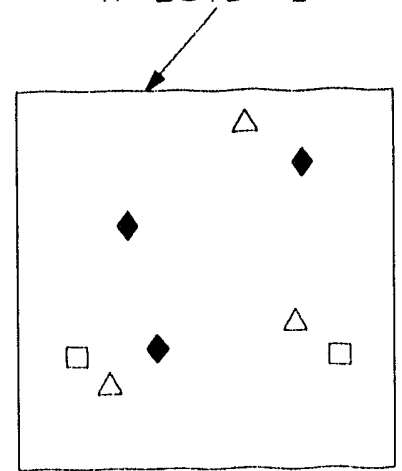

Fig. 4 1. Site map of X-231B indicating the location of three ORNL soil borings made to enable site characterization. 


\subsubsection{On-Site Soil Subsampling}

Subsamples for VOC analyses were collected from each lower 4 -in. sleeve by multiple methods. The multiple methods enabled assessment of potential measurement error, which was important in characterizing the site VOC concentrations, as well as designing and evaluating the Phase 2 Technology Demonstration. The methods used included two methods commonly used today as well as two methods developed in part at ORNL and currently being considered for implementation by EPA and the American Society for Testing and Materials (ASTM). The methods used are described below.

Soil samples for the first three methods were collected using an ORNL developed and patented coring device (Associated Design and Manufacturing); samples for the fourth were collected with a stainless steel spoon. The coring device was used to collect subsamples of $\sim 5-\mathrm{mL}$ volume and extrude them directly into a $40-\mathrm{mL}$ volatile organic acid (VOA) vial. Sample set A was containerized in a $4(0) \mathrm{mL}$ VOA vial closed with a special adaptor cap, designed for direct connection to a purge and trap connected to a gas chromatograph (GC). Sample set B consisted of samples containerized in a $4(0-\mathrm{mL}$ VOA vial that contained $10 \mathrm{~mL}$ of purge and trap grade methanol and then capped with a Teflon-faced septa. Samples in this set were to be analyzed in the laboratory by purge and trap and GC/Mass Spectrometry (MS). Sample set D consisted of samples containerized in 4()-mL VOA vials that contained $10 \mathrm{~mL}$ of distilled water. Samples in this set were used for "screening" for TCE by headspace techniques with a portable GC (Photovac 10S50). Sample set C consisted of samples collected not with the ORNL coring device but rather with a stainless steel spoon. For these samples, soil was packed with a spoon into a 40-mL VOA vial and capped with a Teflon-faced septa.

The four sets of VOC subsamples were collected as follows (Fig. 4.2). The 4-in. sleeve was removed from the split-barrel sampler and placed on aluminum foil. The first sample was collected by method $\mathrm{A}$. Then the core was turned over and rotated $180^{\circ}$, and a duplicate sample was collected. The core was returned to its original position, and a sample was collected at the diametrically opposite side of the core by method $\mathrm{D}$. The core was turned over and rotated $1800^{\circ}$, and a duplicate sample was collected. This process was repeated for samples by methods B and C. After collection, all samples were labeled and then placed in a cooler containing "blue ice." The soil remaining in the 4 -in. and adjacent sleeves were removed and placed into two, 8-oz jars for subsequent analyses of water content, plastic limit, and liquid limit.

The bottom 8-in.-long sleeve was capped on both ends with aluminum foil and plastic covers. This core was placed in a cooler containing blue ice. Soil contained in these cores was used for physical/chemical/biological analyses.

All sampling utensils and apparatus were precleaned prior to sampling. This was done using a laboratory soap wash followed by a tap water, methanol, and distilled water rinse sequence. After this cleaning, the coring devices and sleeves were air-dried and wrapped in clean aluminum foil.

\subsubsection{Analyses}

Laboratory analyses were made for VOC contaminants and physical/chemical/biological properties in soil subsamples collected from each of the two sample depths within each of the three borings.

VOCs were determined in the subsamples collected by the methods described above. VOC screening by headspace analysis was done by the subcontractor, Geraghty \& Miller, Inc., at their offices in Dublin, Ohio. These analyses were made within $1 \mathrm{~d}$ of sample collection. These analyses were made with a portable GC calibrated to TCE, one of the key site contaminants. 

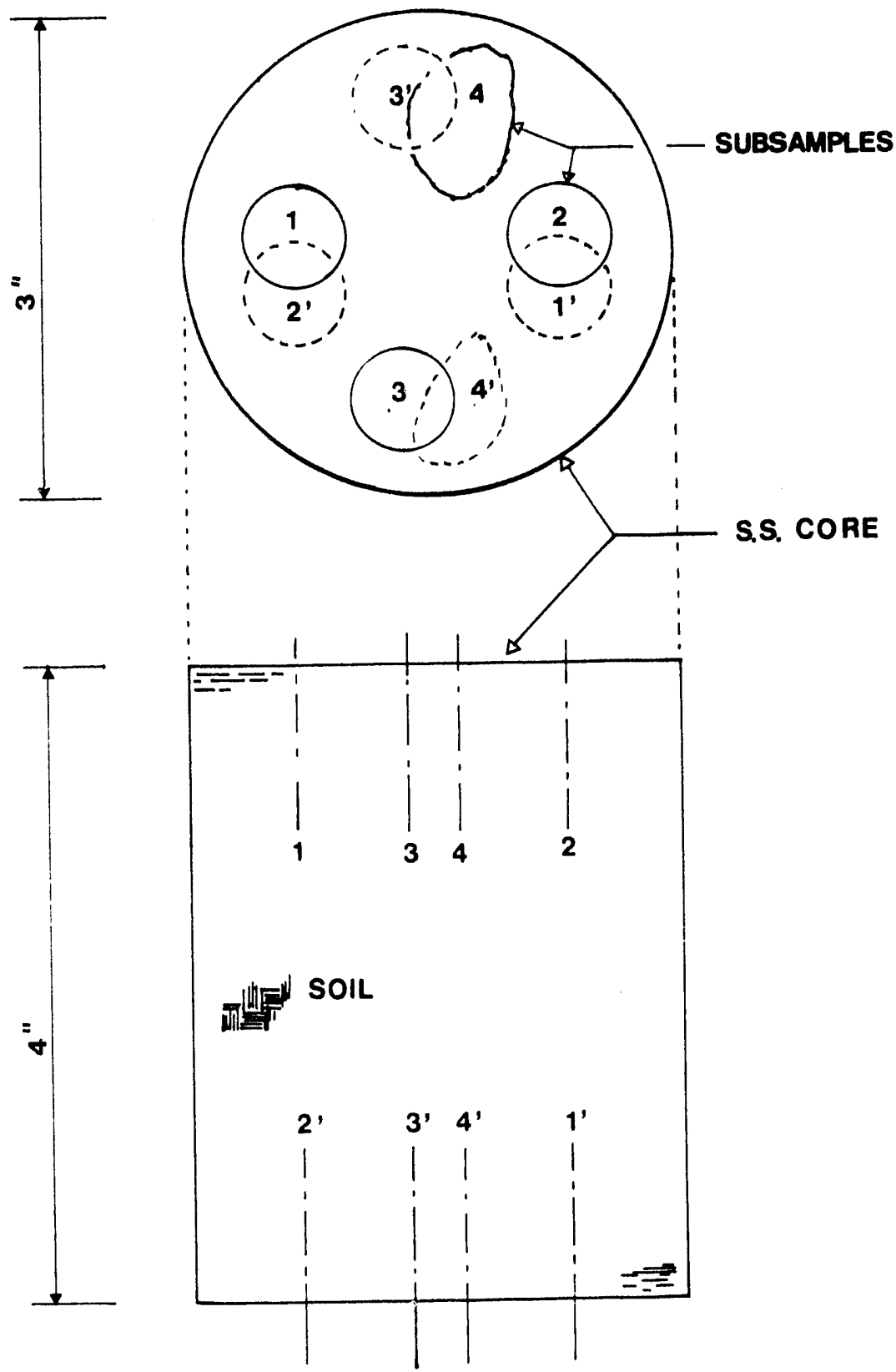

Fig. 4.2. Schematic indicating soil VOC subsample locations within each 4-in.-long stainless steel sleeve.

\section{Methods}

Subsample 1, 1' = Soil plug extruded into purge \& trap VOA vial for lab GC/MS analysis (A).

Subsample 2, 2' = Soil plug extruded into $10 \mathrm{~mL}$ distilled water for field GC analysis (D).

Subsample $3,3^{\prime}=$ Soil plug extruded into $10 \mathrm{~mL}$ methanol for lab GC/MS analysis (B).

Subsample 4, 4' = Packing of soil into VOA vial for lab GC/MS analysis (C). 
Laboratory analyses of VOCs within the other three sample sets were made at laboratories of the Analytical Chemistry Division at ORNL. These samples were analyzed by purge and trap and GC/MS (i.e., EPA method SW5030 or 3580 and SW8240) [6]. For VOC computations, measurements were also made for total sample wet weight and water content.

Physical chemical measurements were made in subsamples collected from five, 8 -in.-long sleeves. These included boring SB01 (shallow and deep), boring SB02 (shallow), and boring SB03 (shallow and deep). Analyses were made for particle size, $\mathrm{pH}$, water content, total organic carbon (TOC), Kjeldahl nitrogen, total phosphorus, total sulfur, and exchangeable cations [7]. These analyses were made in laboratories of the Environmental Sciences Division and the Analytical Chemistry Division at ORNL.

Microbiological measurements were made for total bacteria (colony forming units) and methanotrophs at laboratories of the Environmental Sciences Division of ORNL [8].

Finally, water content measurements were also made in soil samples collected from each interval by the subcontractor, Geraghty \& Miller, Inc. Measurements of liquid limit and plastic limit were made at the 16 - to 18 - $\mathrm{ft}$ interval by the subcontractor.

\subsection{RESULTS AND DISCUSSION}

The subsurface conditions encountered in the borings made in X-231B are graphically depicted in the stratigraphic cross section shown in Fig. 4.3. The detailed boring logs may be found in Appendix A.

The results of water content measurements with depth are shown in Table 4.1. Rather than a uniformly increasing water content with depth, there were variations with depth. There appeared to be a wet-to-saturated zone at a depth of $\sim 4$ to $6 \mathrm{ft}$. At 10- to 12-ft depth, the previously reported groundwater table depth, the water content approached $25 \mathrm{wt} \%$. This was presumed to be saturation, which is consistent with the liquid limit measurements of $\sim 25 \mathrm{wt} \%$ (see Table 4.2).

The soil in the shallow unsaturated zone (Minford Member upper unit) was characterized as relatively moist, fine-grained media, with a moderately acidic $\mathrm{pH}$ (Table 4.2 ). The TOC was in the 0.05 to $0.10 \mathrm{wt} \%$ range. Nitrogen and phosphorus were present at concentrations of $\sim 0.050$ and $0.007 \mathrm{wt} \%$, respectively. In the saturated zone (Minford Member lower unit), the soil was more coarse-grained and of neutral $\mathrm{pH}$. In this zone, the silt and clay contents were lower. Also lower was the TOC, although the nitrogen and phosphorus contents remained largely the same.

The soil samples collected at $\sim 7$-ft depth contained bacteria at levels of approximately $10^{4}$ to $10^{5}$ colony forming units per gram (CFU/g). Bacteria were not detected at 17-ft depth (detection limit $\sim 10^{2} \mathrm{CFU} / \mathrm{g}$ ). Bacterial concentrations detected at $7-\mathrm{ft}$ depth are typical of those found at other contaminated sites. The absence of bacteria at $17-\mathrm{ft}$ depth may be related to the site environmental conditions (i.e., dense, saturated soil at depth below a geomembrane cap). Methanotrophic bacteria were present in samples from 7 - $\mathrm{ft}$ depth. The enrichment technique used is not quantitative, but the finding of methanotrophs does indicate the potential for enrichment of these types of important biodegradative bacteria at the site.

The results of soil VOC screening by headspace techniques within $24 \mathrm{~h}$ using a portable GC are summarized in Table 4.3. These data are qualitative and provide a relative measure of the total VOCs present. As shown in Table 4.3, the field GC data revealed varying levels of VOCs, reported in headspace parts per million ( $\mathrm{ppm}_{\mathrm{V}}$ ) as TCE. In general, VOCs were detected in all of the samples analyzed, although the concentrations ranged over several orders of magnitude. 

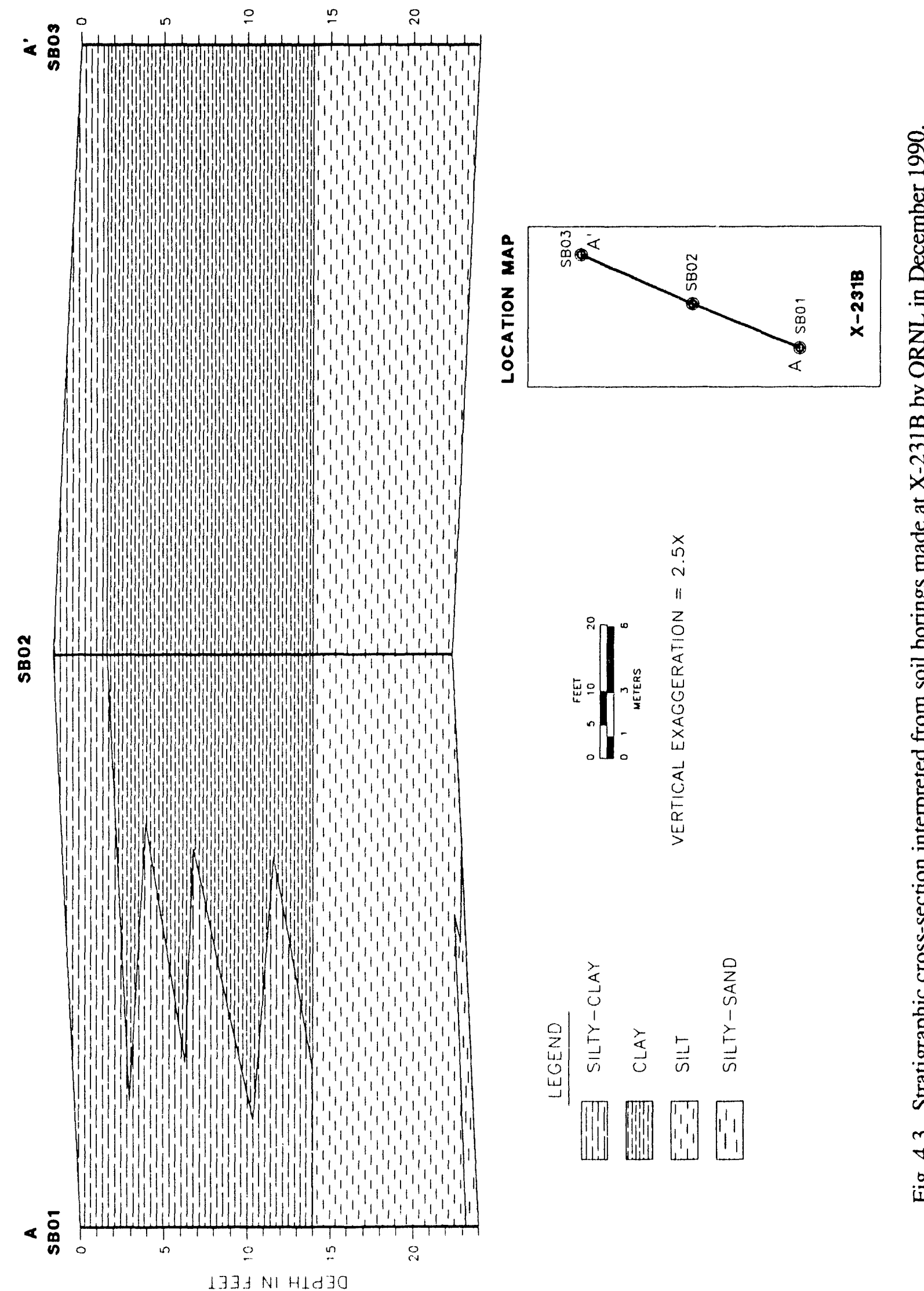

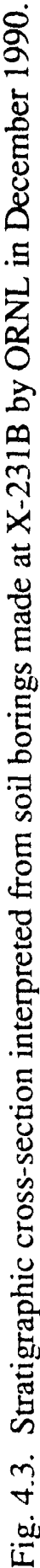


Laboratory analyses were made for a wide variety of VOCs by GC/MS. Analyses were made for over 50 VOCs, but only 13 VOCs were detected. TCE, TCA, 1,1-dichloroethene (1,1-DCE), and $\mathrm{MC}$ were most prevalent in the samples and at the highest concentrations (Table 4.4 and 4.5 , Appendix B). TCE and TCA were present at concentrations ranging from several hundred to several thousand micrograms per kilogram of soil.

The spatial variability across the $\mathrm{X}-231 \mathrm{~B}$ unit is pronounced. The highest concentrations were found in the unsaturated zone ( 7-ft depth) near the center of the plot (Fig. 4.4). Comparatively lower concentrations were found in the saturated zone $(\sim 17-\mathrm{ft}$ depth) and toward the edges of the plot.

The correlation was reasonably good between VOCs detected by the screening analysis of soil headspace using a field-portable GC and the laboratory analysis of the total soil sample conducted by GC/MS (Fig. 4.4).

The VOC concentrations measured by the three different sampling techniques were substantially different. The soil VOC concentrations measured by commonly used RCRA methods (RFI) were consistently lower ( 50 to $90 \%+$ ) than those measured by more rigorous ORNL methods [modified purge \& trap (MP\&T); methanol method (MeOH)] (Tables 4.4 and 4.5; Fig. 4.4). ORNL research has documented this sampling method effect previously [9].

Apart from documenting the potential measurement error associated with conventional sampling methods, the laboratory data provide some insight into the removal/degradation potential of the VOCs upon disturbance and holding, even at low temperatures. The differences between the conventional RFI and the MP\&T method could be attributable to volatilization losses induced by disturbance (i.e., during sample collection, containerization, or laboratory subsampling). The differences between the MP\&T and the infield immersion in MeOH may be attributable to VOC losses due to vapor leakage from the containers and/or degradation. Alternatively, the differences could have been caused by firmly sorbed VOCs that were not extracted in either the conventional or MP\&T sampling/analysis techniques (i.e., with water as the extraction fluid rather than methanol).

The VOCs identified and the concentrations measured in this site characterization study were contrasted with those measured previously during 1986-1987 (see Table 2.1; Fig. 2.3). Consistent with the previous study, the principal VOCs detected in the current study were TCE, TCA, MC, and 1,1-DCE. However, the prevalence and high concentrations of acetone and Freon 113 determined in the previous study were not found in the current study. Although the concentrations measured in the current study were within the range of those measured previously, casual comparison of the two data sets suggests that the concentrations measured in December 1990 might have been lower than those measured several years earlier, particularly within the saturated zone. It is unknown if real differences exist or if the apparent differences are artifacts of the measurement process. Current VOC concentrations could in fact be lower as a result of VOC leaching and/or biodegradation during the approximately 3.3 years since the previous sampling. Because the site has been covered with a geomembrane cap since late 1987, it is unlikely that atmospheric volatilization losses have been significant. Alternatively, the apparent differences could be the result of normal spatial and temporal variability of the contaminant concentrations or differences in soil sampling and analysis techniques. 
Table 4.1. Soil percent moisture at the X-231B site as measured in soil samples collected by ORNL in December 1990. a

\begin{tabular}{|c|c|c|c|c|}
\hline \multirow[b]{2}{*}{$\begin{array}{l}\text { Depth interval } \\
\text { (ft below ground) }\end{array}$} & \multirow[b]{2}{*}{ Units } & \multicolumn{3}{|c|}{ Boring number and location $\underline{b}$} \\
\hline & & $\begin{array}{c}\text { SB01 } \\
\text { (Southwest) }\end{array}$ & $\begin{array}{c}\text { SB02 } \\
\text { (Center) }\end{array}$ & $\begin{array}{c}\mathrm{SB03} \\
\text { (Northeast) }\end{array}$ \\
\hline 2.0 to 4.0 & $w t \%$ & 17.25 & 14.10 & 18.98 \\
\hline 4.0 to 6.0 & wt\% & 21.68 & 24.85 & 26.41 \\
\hline 6.0 to 8.0 & $w t \%$ & 17.87 & 18.67 & 20.12 \\
\hline 6.0 to 8.0 & $w t \%$ & $16.99 \underline{\mathrm{c}}$ & - & $15.58 \mathrm{c}$ \\
\hline 10.0 to 12.0 & $w t \%$ & 24.40 & 25.14 & 22.69 \\
\hline 16.0 to 18.0 & $w t \%$ & 23.05 & 23.50 & 23.37 \\
\hline 16.0 to 18.0 & $w t \%$ & $24,08 \mathrm{c}$ & & $23.30 \mathrm{c}$ \\
\hline 22.0 to 24.0 & $\mathrm{wt} \%$ & 24.97 & 27.69 & 26.99 \\
\hline
\end{tabular}

a Water content data shown are percent moisture as reported by Geraghty \& Miller, Inc., Dublin, $\mathrm{OH}$.

b Refer to Fig. 4.1 for sample locations.

c Duplicate sample analysis. 
Table 4.2. Characteristics of subsurface soil at the X-231B site as measured in samples collected by ORNL in December 1990.

\begin{tabular}{|c|c|c|c|c|c|c|}
\hline \multirow[b]{3}{*}{ Characteristic a } & \multicolumn{6}{|c|}{ Nominal depth and boring location $b$} \\
\hline & \multicolumn{3}{|c|}{ Shallow (7-ft depth) } & \multicolumn{3}{|c|}{ Deep (17-ft depth) } \\
\hline & SB01 & $\mathrm{SB}(02$ & SB03 & SB01 & $\mathrm{SB} 02$ & $\mathrm{SB}(03$ \\
\hline Depth, $\mathrm{ft}$ & 7.2 & 6.2 & 6.2 & 17.2 & 17.2 & 17.2 \\
\hline $\begin{array}{l}\text { Particle size distribution: } \\
\text { Clay: }<0.002 \mathrm{~mm} \text {, wt } \% \\
\text { Silt: } 0.002-0.05 \mathrm{~mm} \text {, wt } \% \\
\text { Sand: } 0.05-2.0 \mathrm{~mm} \text {, wt } \% \\
\text { Water content, dry wt } \%\end{array}$ & $\begin{array}{l}22.5 \\
6.5 .5 \\
12.0 \\
17.6\end{array}$ & $\begin{array}{l}\underline{\mathrm{c}} \\
\mathrm{c} \\
\underline{\mathrm{c}} \\
\underline{\mathrm{c}}\end{array}$ & $\begin{array}{r}25.0 \\
67.0 \\
8.0 \\
19.0\end{array}$ & $\begin{array}{l}14.0 \\
64.0 \\
22.0 \\
23.5\end{array}$ & $\begin{array}{l}12.0 \\
55.0 \\
33.0 \\
23.5\end{array}$ & $\begin{array}{l}15.0 \\
39.0 \\
46.0 \\
22.0\end{array}$ \\
\hline $\begin{array}{l}\text { Percent solids, wt } \% \\
\text { pH } \\
\text { Total organic carbon , mg/kg } \\
\text { Kjeldahl nitrogen, } \mathrm{mg} / \mathrm{kg} \\
\text { Total phosphorus, } \mathrm{mg} / \mathrm{kg} \\
\text { Total sulfur, } \mathrm{mg} / \mathrm{kg}\end{array}$ & $\begin{array}{c}86.6 \\
5.32 \\
579 \\
<500 \\
66 \\
24\end{array}$ & $\begin{array}{l}\underline{\mathrm{c}} \\
\mathrm{c} \\
\underline{\mathrm{c}} \\
\underline{\mathrm{c}} \\
\mathrm{c} \\
\underline{\mathrm{c}}\end{array}$ & $\begin{array}{c}81.0 \\
5.96 \\
1190 \\
<500 \\
66 \\
<10\end{array}$ & $\begin{array}{l}81.8 \\
7.40 \\
245 \\
<500 \\
66 \\
23\end{array}$ & $\begin{array}{c}81.0 \\
6.16 \\
184 \\
<500 \\
73 \\
30\end{array}$ & $\begin{array}{l}\quad 81.2 \\
\quad 7.01 \\
472 \\
<500 \\
108 \\
<10\end{array}$ \\
\hline $\begin{array}{l}\text { Exchangeable cations: } \underline{\mathrm{d}} \\
\text { Calcium, mg/L } \\
\text { Magnesium, mg/L } \\
\text { Sodium, mg/L } \\
\text { Potassium, mg/L }\end{array}$ & $\begin{array}{l}47 \\
42 \\
9.4 \\
6.3\end{array}$ & $\begin{array}{l}\underline{c} \\
\mathfrak{c} \\
\underline{c} \\
\underline{c}\end{array}$ & $\begin{array}{c}48 \\
31 \\
6.0 \\
4.5\end{array}$ & $\begin{array}{l}60 \\
28 \\
10.6 \\
6.0\end{array}$ & $\begin{array}{c}37 \\
25 \\
3.1 \\
4.0\end{array}$ & $\begin{array}{l}71 \\
34 \\
15.1 \\
5.0\end{array}$ \\
\hline 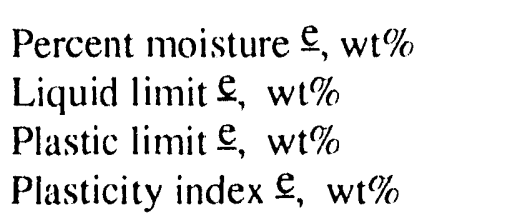 & $\begin{array}{l}17.9 \\
c \\
\underline{c} \\
\underline{c}\end{array}$ & $\begin{array}{l}18.7 \\
\mathrm{c} \\
\underline{c} \\
\underline{c}\end{array}$ & $\begin{array}{l}20.1 \\
\stackrel{c}{c} \\
\underline{c} \\
\underline{c}\end{array}$ & $\begin{array}{r}23.0 \\
25.30 \\
22.19 \\
3.11\end{array}$ & $\begin{array}{l}23.5 \\
25.55 \\
22.63 \\
2.92\end{array}$ & $\begin{array}{r}23.4 \\
25.73 \\
20.56 \\
5.17\end{array}$ \\
\hline Total bacteria, CFU/g & $2.26 \mathrm{E}(04$ & $2.37 \mathrm{E}(05$ & $1.02 \mathrm{E} 04$ & $<1 \mathrm{E} 02$ & $<1 \mathrm{E} 02$ & $<1 \mathrm{E}(0) 2$ \\
\hline Methanotrophs & Detected & Detected & Detected & $\begin{array}{l}\text { Not } \\
\text { Detected }\end{array}$ & $\begin{array}{l}\text { Not } \\
\text { Detected }\end{array}$ & $\begin{array}{l}\text { Not } \\
\text { Detected }\end{array}$ \\
\hline
\end{tabular}

a Results of analyses are expressed on a field moist soil weight basis unless otherwise indicated.

b Refer to Fig. 4.1 for sample locations.

c Indicates analyses not performed.

d Averages of duplicate analyses; coefficient of variation for duplicates was $<5 \%$.

e Percent moisture (wet wt. \%) analyses performed by Geraghty \& Miller, Inc., Dublin, OH. 
Table 4.3. Headspace VOC concentrations in soil samples collected at X-231B by ORNL in December 1990. a

\begin{tabular}{|c|c|c|c|c|}
\hline \multirow[b]{2}{*}{ Depth $(\mathrm{ft})$} & \multirow[b]{2}{*}{ Units } & \multicolumn{3}{|c|}{ Boring number and location $\underline{b}$} \\
\hline & & $\begin{array}{c}\text { SB01 } \\
\text { (Southwest) }\end{array}$ & $\begin{array}{c}\text { SB02 } \\
\text { (Center) }\end{array}$ & $\begin{array}{c}\mathrm{SB03} \\
\text { (Northeast) } \\
\end{array}$ \\
\hline 0.0 to 2.0 & $\mathrm{ppm}_{\mathrm{V}} \mathrm{TCE}$ & 1.60 & 56.21 & 13.06 \\
\hline 2.0 to 4.0 & $\mathrm{ppm}_{V}$ TCE & - & - & 5.42 \\
\hline 4.0 to 6.0 & $\mathrm{ppm}_{\mathrm{V}} \mathrm{TCE}$ & 3.07 & 99.55 & 8.82 \\
\hline 6.0 to 8.0 & $\mathrm{ppm}_{\mathrm{V}} \mathrm{TCE}$ & $\begin{array}{c}2.58 \\
\{2.40\} \mathcal{E}\end{array}$ & $\begin{array}{c}84.94 \\
\{62.32\}\end{array}$ & $\begin{array}{c}4.28 \\
\{4.30\}\end{array}$ \\
\hline 10.0 to 12.0 & $\mathrm{ppm}_{V}$ TCE & 2.26 & 18.69 & 1.29 \\
\hline 16.0 to 18.0 & $\mathrm{ppm}_{\mathrm{V}} \mathrm{TCE}$ & $\begin{array}{c}6.98 \\
\{7.16\}\end{array}$ & $\begin{array}{c}0.221 \\
\{0.181\}\end{array}$ & $\begin{array}{c}1.33 \\
\{1.19\}\end{array}$ \\
\hline 22.0 to 24.0 & $\mathrm{ppm}_{\mathrm{V}} \mathrm{TCE}$ & 30.20 & 0.127 & 7.00 \\
\hline
\end{tabular}

a Data shown are based on gas-phase VOC analyses using a portable GC (Photovac 10S series) calibrated to TCE and headspace techniques with $\sim 5 \mathrm{~mL}$ of soil immersed in $10 \mathrm{~mL}$ distilled water within a 40-mL VOA vial with Teflon sealed cap. Analyses were made by Geraghty \& Miller, Inc. within $1 \mathrm{~d}$ of sample collection.

b Refer to Fig. 4.1 for sample locations.

c Number in brackets is the result of a duplicate analysis of the same sample. 
Table 4.4. Average concentrations of principal VOCs at the X-231B site as measured in soil samples collected by ORNL in December 1990, $\underline{\mathrm{a}}$

\begin{tabular}{|c|c|c|c|c|c|c|c|c|}
\hline \multirow{3}{*}{$\begin{array}{l}\text { Principal } \\
\text { VOCs }\end{array}$} & \multirow{3}{*}{$\begin{array}{l}\text { Sampling } \\
\text { method } \underline{\mathrm{b}}\end{array}$} & \multirow[b]{3}{*}{ Units } & \multicolumn{6}{|c|}{ VOC at depth and location $\underline{a}$} \\
\hline & & & \multicolumn{3}{|c|}{ Shallow (7-ft depth) } & \multicolumn{3}{|c|}{ Deep (17-ft depth) } \\
\hline & & & SB01 & $\mathrm{SB} 02$ & SB03 & SB01 & SB02 & $\mathrm{SB} 03$ \\
\hline Trichloroethene & Field GC & $\mathrm{ppm}_{\mathrm{V}} \mathrm{TCE}$ & 2.5 & 74 & 4.3 & 7.1 & 0.20 & 1.3 \\
\hline & $\begin{array}{l}\text { RFI } \\
\text { MP\&T } \\
\text { MeOH }\end{array}$ & $\begin{array}{l}\mu \mathrm{g} / \mathrm{kg} \\
\mu \mathrm{g} / \mathrm{kg} \\
\mu \mathrm{g} / \mathrm{kg}\end{array}$ & $\begin{array}{r}16 \\
110 \\
350\end{array}$ & $\begin{array}{l}1236 \\
1808 \\
7700\end{array}$ & $\begin{array}{l}205 \\
384 \\
300\end{array}$ & $\begin{array}{r}40 \\
159 \\
302\end{array}$ & $\begin{array}{r}35 \\
14 \\
592\end{array}$ & $\begin{array}{r}17 \\
42 \\
\text { c }\end{array}$ \\
\hline $\begin{array}{l}1,1,1- \\
\text { Trichloroethane }\end{array}$ & $\begin{array}{l}\text { RFI } \\
\text { MP\&T } \\
\text { MeOH }\end{array}$ & $\begin{array}{l}\mu \mathrm{g} / \mathrm{kg} \\
\mu \mathrm{g} / \mathrm{kg} \\
\mu \mathrm{g} / \mathrm{kg}\end{array}$ & $\begin{array}{r}c \\
64 \\
c\end{array}$ & $\begin{array}{r}58 \\
1028 \\
298\end{array}$ & $\begin{array}{r}427 \\
1240 \\
858\end{array}$ & $\begin{array}{r}18 \\
78 \\
\mathrm{c}\end{array}$ & $\begin{array}{r}6 \\
30 \\
\text { c }\end{array}$ & $\begin{array}{r}72 \\
250 \\
\underline{\mathrm{c}}\end{array}$ \\
\hline $\begin{array}{r}\text { Methylene } \\
\text { Chloride }\end{array}$ & $\begin{array}{l}\text { RFI } \\
\text { MP\&T } \\
\text { MeOH }\end{array}$ & $\begin{array}{l}\mu \mathrm{g} / \mathrm{kg} \\
\mu \mathrm{g} / \mathrm{kg} \\
\mu \mathrm{g} / \mathrm{kg}\end{array}$ & $\begin{array}{r}2 \\
\underline{c} \\
52\end{array}$ & $\begin{array}{r}1 \\
1 \\
50\end{array}$ & $\begin{array}{r}6 \\
7 \\
60\end{array}$ & $\begin{array}{r}2 \\
1 \\
43\end{array}$ & $\begin{array}{r}2 \\
1 \\
58\end{array}$ & $\begin{array}{r}11 \\
2 \\
64\end{array}$ \\
\hline $\begin{array}{l}\text { 1,1-Dichloro- } \\
\text { ethene }\end{array}$ & $\begin{array}{l}\text { RFI } \\
\text { MP\&T } \\
\text { MeOH }\end{array}$ & $\begin{array}{l}\mu \mathrm{g} / \mathrm{kg} \\
\mu \mathrm{g} / \mathrm{kg} \\
\mu \mathrm{g} / \mathrm{kg}\end{array}$ & $\begin{array}{r}c \\
64 \\
\underline{c}\end{array}$ & $\begin{array}{r}35 \\
464 \\
178\end{array}$ & $\begin{array}{r}193 \\
1488 \\
746\end{array}$ & $\begin{array}{r}12 \\
47 \\
\text { c }\end{array}$ & $\begin{array}{r}\underline{c} \\
44 \\
\underline{c}\end{array}$ & $\begin{array}{r}27 \\
382 \\
165\end{array}$ \\
\hline $\begin{array}{l}\text { 1,2-Dichloro- } \\
\text { ethene }\end{array}$ & $\begin{array}{l}\text { RFI } \\
\text { MP\&T } \\
\text { MeOH }\end{array}$ & $\begin{array}{l}\mu \mathrm{g} / \mathrm{kg} \\
\mu \mathrm{g} / \mathrm{kg} \\
\mu \mathrm{g} / \mathrm{kg}\end{array}$ & $\begin{array}{l}\mathrm{c} \\
3 \\
\mathrm{c}\end{array}$ & $\begin{array}{r}9 \\
44 \\
c\end{array}$ & $\begin{array}{r}20 \\
45 \\
c\end{array}$ & $\begin{array}{l}\frac{c}{4} \\
\mathrm{c}\end{array}$ & $\begin{array}{l}\underline{c} \\
\mathrm{c} \\
\mathrm{c}\end{array}$ & $\begin{array}{l}\frac{c}{6} \\
\mathrm{c}\end{array}$ \\
\hline
\end{tabular}

9. Average results are expressed on a dry weight basis (Appendix B). Refer to Fig. 4.1 for sample locations. Additional VOCs identified, but in only a few samples and at low $\mu \mathrm{g} / \mathrm{kg}$ concentrations were 1,2-dichloroethane, chloroform, tetrachloroethene, acetone, 2-butanone, carbon disulfide, carborr ietrachloride, and vinyl chloride (see Appendix B).

b RFI (Conventional RCRA) = soil sample packed into 4()-mL VOA vial with Teflon septa sealed cap. Laboratory subsampling and analyses by purge and trap and GC/MS per EPA Method SW8240.

MP\&T (Modified purge \& trap) = soil sample extruded from 5 -mL coring device into $40-\mathrm{mL}$ VOA vial with 0 ring sealed cap made to adapt directly to a purge and trap instrument connected to a GC/MS. Thus, laboratory subsampling is precluded. VOC analyses by GC/MS per EPA Method SW8240.

$\mathrm{MeOH}$ (Methanol immersion) = soil sample extruded from $5-\mathrm{mL}$ coring device into 40 )-mL. VOA vial containing $10 \mathrm{~mL}$ of purge and trap grade methanol and capped with a Teflon septa sealed cap. Laboratory subsampling of the methanol extract and analysis by GC/MS per EPA Method SW8240.

Field $\mathrm{GC}=$ soil sample extruded from $5-\mathrm{mL}$ coring device into $40-\mathrm{mL}$ VOA vial containing $10 \mathrm{~mL}$ of distilled water and capped with a Teflon septa sealed cap. Analysis of VOCs in headspace by portable GC/PID.

c Indicates VOC not detected. 
Table 4.5. Total VOC concentrations at X-231B as measured in soil samples collected by ORNL in December 1990. a

\begin{tabular}{|c|c|c|c|c|c|c|c|c|}
\hline \multirow[b]{2}{*}{ Method $\underline{b}$} & \multirow[b]{2}{*}{ Statistic } & \multirow[b]{2}{*}{ Units } & \multicolumn{6}{|c|}{ Total VOCs at depth and boring location a } \\
\hline & & & $\begin{array}{r}\text { Sh } \\
\text { SB01 } \\
\end{array}$ & $\begin{array}{c}\text { llow }(7-\mathrm{ft} d \\
\mathrm{SB} 02 \\
\end{array}$ & $\begin{array}{l}\text { pth) } \\
\text { SB03 }\end{array}$ & $\begin{array}{r}\text { De } \\
\text { SB01 } \\
\end{array}$ & $\begin{array}{l}(17-\mathrm{ft} \\
\text { SB02 } \\
\end{array}$ & $\begin{array}{l}\text { epth) } \\
\text { SB03 }\end{array}$ \\
\hline $\begin{array}{l}\text { Conventional } \\
\text { RFI }\end{array}$ & $\begin{array}{l}\text { Dup. C1 } \\
\text { Dup. C2 } \\
\text { Average } \\
\text { Std.Dev. } \\
\text { C.V. }\end{array}$ & $\begin{array}{l}\mu \mathrm{g} / \mathrm{kg} \\
\mu \mathrm{g} / \mathrm{kg} \\
\mu \mathrm{g} / \mathrm{kg} \\
\mu \mathrm{g} / \mathrm{kg}\end{array}$ & $\begin{array}{l}16 \\
20 \\
18 \\
2.8 \\
0.16\end{array}$ & $\begin{array}{l}505 \\
2129 \\
1317 \\
1148 \\
0.87\end{array}$ & $\begin{array}{l}929 \\
772 \\
850 \\
111 \\
0.13\end{array}$ & $\begin{array}{c}54 \\
92 \\
73 \\
27 \\
0.37\end{array}$ & $\begin{array}{c}66 \\
13 \\
40 \\
37 \\
0.94\end{array}$ & $\begin{array}{c}131 \\
7 \\
69 \\
88 \\
1.27\end{array}$ \\
\hline $\begin{array}{l}\text { Modified } \\
\text { purge \& trap }\end{array}$ & $\begin{array}{l}\text { Dup. A1 } \\
\text { Dup. A2 } \\
\text { Average } \\
\text { Std. Dev. } \\
\text { C.V. }\end{array}$ & $\begin{array}{l}\mu \mathrm{g} / \mathrm{kg} \\
\mu \mathrm{g} / \mathrm{kg} \\
\mu \mathrm{g} / \mathrm{kg} \\
\mu \mathrm{g} / \mathrm{kg}\end{array}$ & $\begin{array}{r}\underline{\mathbf{c}} \\
241 \\
- \\
-\end{array}$ & $\begin{array}{c}3896 \\
2795 \\
3346 \\
779 \\
0.23\end{array}$ & $\begin{array}{c}\text { c } \\
3164 \\
- \\
- \\
-\end{array}$ & $\begin{array}{l}60 \\
514 \\
287 \\
321 \\
1.19\end{array}$ & $\begin{array}{l}81 \\
96 \\
88 \\
10.6 \\
0.12\end{array}$ & $\begin{array}{r}682 \\
\mathrm{c} \\
- \\
-\end{array}$ \\
\hline $\begin{array}{l}\text { Methanol } \\
\text { immersion }\end{array}$ & $\begin{array}{l}\text { Dup. B1 } \\
\text { Dup. B2 } \\
\text { Average } \\
\text { Std.Dev. } \\
\text { C.V. }\end{array}$ & $\begin{array}{l}\mu \mathrm{g} / \mathrm{kg} \\
\mu \mathrm{g} / \mathrm{kg} \\
\mu \mathrm{g} / \mathrm{kg} \\
\mu \mathrm{g} / \mathrm{kg}\end{array}$ & $\begin{array}{l}346 \\
458 \\
402 \\
79 \\
0.20\end{array}$ & $\begin{array}{c}8464 \\
7809 \\
8136 \\
463 \\
0.06\end{array}$ & $\begin{array}{c}2191 \\
1737 \\
1964 \\
321 \\
0.16\end{array}$ & $\begin{array}{l}396 \\
294 \\
345 \\
72 \\
0.21\end{array}$ & $\begin{array}{r}609 \\
690 \\
650 \\
57 \\
0.09\end{array}$ & $\begin{array}{r}284 \\
206 \\
245 \\
55 \\
0.22\end{array}$ \\
\hline Field GC & $\begin{array}{l}\text { Dup. D1 } \\
\text { Dup. D2 } \\
\text { Average } \\
\text { Std. Dev. } \\
\text { C.V. }\end{array}$ & $\begin{array}{l}\mathrm{ppm}_{\mathrm{V}} \text { TCE } \\
\mathrm{ppm}_{\mathrm{V}} \text { TCE } \\
\mathrm{ppm}_{\mathrm{V}} \text { TCE } \\
\mathrm{ppm}_{\mathrm{V}} \text { TCE }\end{array}$ & $\begin{array}{l}2.58 \\
2.40 \\
2.49 \\
0.13 \\
0.05\end{array}$ & $\begin{array}{c}84.9 \\
62.3 \\
73.6 \\
16.0 \\
0.22\end{array}$ & $\begin{array}{l}4.28 \\
4.30 \\
4.29 \\
0.01 \\
0.003\end{array}$ & $\begin{array}{l}6.98 \\
7.16 \\
7.08 \\
0.11 \\
0.02\end{array}$ & $\begin{array}{l}0.22 \\
0.18 \\
0.20 \\
0.03 \\
0.14\end{array}$ & $\begin{array}{l}1.33 \\
1.19 \\
1.26 \\
0.10 \\
0.08\end{array}$ \\
\hline
\end{tabular}

a Total VOCs $=$ summation of TCE, TCA, 1,1-DCE, 1,2-DCE, and MeCL. VOC results are expressed on a dry soil weight basis. Refer to Fig. 4.1 for sample locations.

b Conventional RFI = soil sample packed into $40-\mathrm{mL}$ VOA vial with Teflon septa sealed cap. Laboratory subsampling and analyses by purge and trap and GC/MS.

Modified purge \& trap = soil sample extruded from $5-\mathrm{mL}$ coring device into $40-\mathrm{mL}$ VOA vial with o-ring sealed cap made to adapt directly to a purge and trap instrument connected to a GC/MS. Thus, laboratory subsampling is precluded.

Methanol immersion $=$ snil sample extruded from $5-\mathrm{mL}$ coring device into $40-\mathrm{mL}$ VOA vial containing $10 \mathrm{~mL}$ of purge and trap grade methanol and capped with a Teflon septa sealed cap. Laboratory subsampling of the methanol extract and analysis by purge and trap and GC/MS.

Field GC = soil sample extruded from 5-mL coring device into $40-\mathrm{mL}$ VOA vial containing $10 \mathrm{~mL}$ of distilled water and capped with a Teflon septa sealed cap. Analysis of VOCs in headspace by portable GC equipped with a photoionization detector (PID).

$\subseteq$ Indicates mechanical malfunction during analysis. 


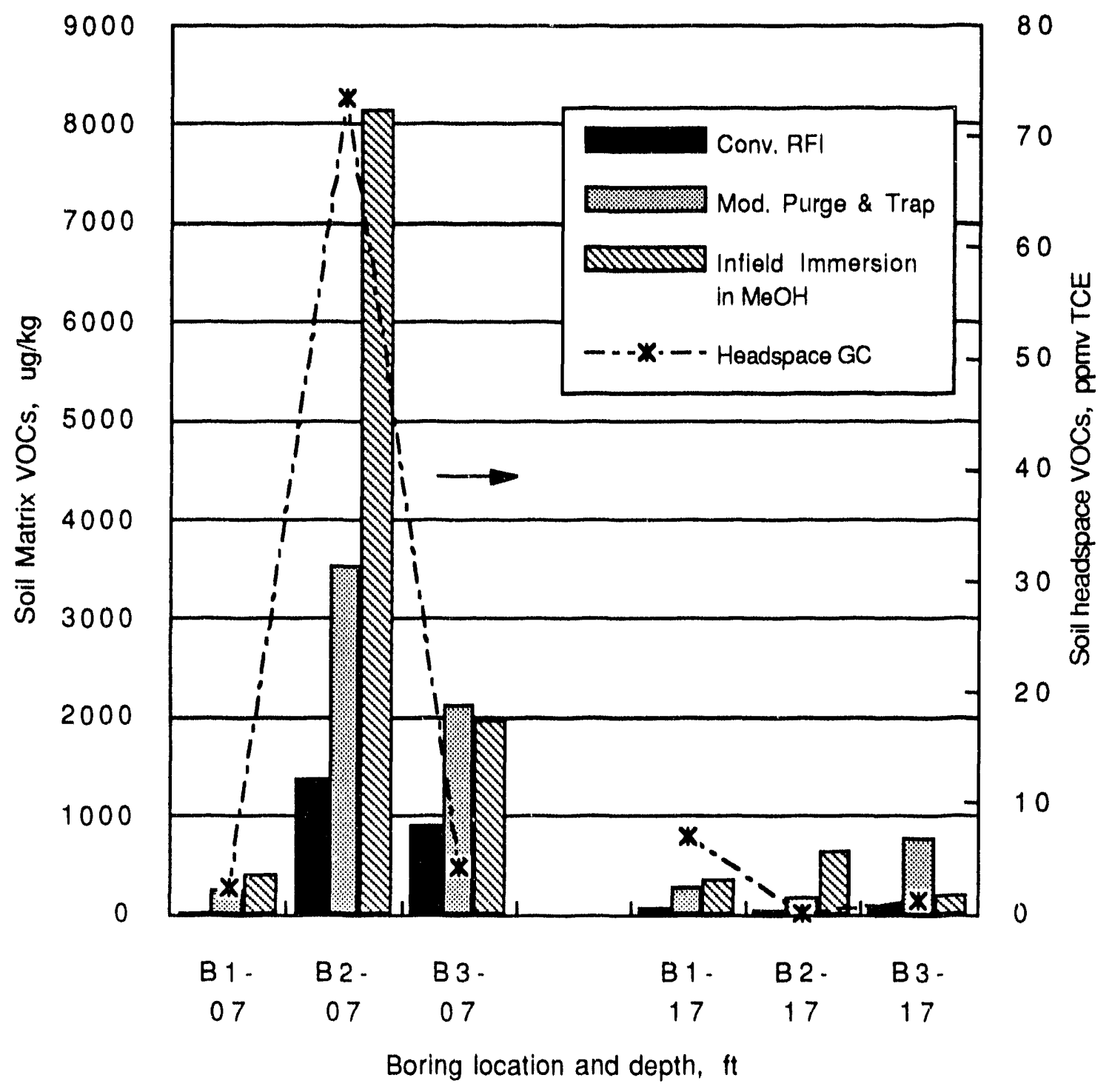

Fig. 4.4. Concentrations of total soil VOCs measured by conventional and modified techniques in soil samples collected at the X-231B site by ORNL in December 1990. (Soil matrix VOCs = summation of TCE, TCA, 1,1-DCE, 1,2-DCE, and $\mathrm{MeCl}$, expressed on a dry soil weight basis) 


\subsection{SOIL TREATMENT TECHNOLOGIES}

\subsection{INTRODUCTION}

During pre-project planning meetings in late October and early November 1990, a list of candidate technologies was developed based on the expertise of individual project team members and knowledge of the site conditions and contamination at PORTS X-231B. This candidate list included several technologies judged to be appropriate for further consideration (see Table 1.1). A critical part of the Phase 1 study was to evaluate and rank the candidate technologies and develop a strategy for the technology demonstration, testing, and evaluation to occur during Phase 2.

\subsection{MATERIALS AND METHODS}

The task of evaluating the different candidate technologies was undertaken, recognizing that extensive literature review, detailed analysis, and laboratory treatability studies could not be accomplished in the extremely short time allotted for conducting this Phase 1 work. Thus, the evaluation consisted of literature review, personal inquiries, and assimilation of prior experience of individual project team members.

During the first few weeks of this Phase 1 effort, the original candidate technology list was reviewed and reconsidered in light of increasing knowledge about the site characteristics and contamination levels compared with potentially viable soil treatment technologies $|10-12|$. The final list of technologies identified for evaluation and screening is shown in Table 5.1.

\subsubsection{Technology Descriptions}

Each of the technologies identified for consideration (Table 5.1) was reviewed and assessed in varying detail by members of the project team. To facilitate this effort and to enable rapid review and understanding, a Technology Description Fact Sheet was developed on which key information regarding each technology could be recorded. These descriptions were prepared based on information gathered from several sources, including existing awareness of a technology, literature review, personal inquiries, and vendor information.

\subsubsection{Technology Vendor Inquiry}

To provide information on the stage of development and commercial availability of the candidate technologies, information was solicited from a selected number of technology vendors known to members of the project team with potential for providing one or more of the candidate technologies. A letter of incuiry was prepared along with a short narrative describing the site characteristics of interest. PORTS or X-231B were intentionally not mentioned in any correspondence or communications. A form was provided to guide the vendors' responses and to facilitate interpretation and comparison. A copy of this information is presented in Appendix $C$. 
Table 5.1. Revised list of candidate soil treatment technologies for demonstration at the $\mathrm{X}$-231B Oil Biodegradation Unit at PORTS. a

Soil treatment technology

In situ immobilization

In situ hot-air and/or steam stripping

In situ electrokinetics

In situ jet mixing and slurry reactor

In situ $\mathrm{EM} / \mathrm{RF}$ heating

In situ (ex situ ) hydrogen peroxide

Ex situ thermal treatment

Ex situ immobilization
Technology description

Soil mixing by auger or jet system with addition of solidification/immobilization agent to solidify soil mass and immobilize VOCs and other contaminants in place

Soil mixing by dual auger system with injection of hot air and/or steam to raise soil temperature and volatilize VOCs

Application of electrical energy to the soil mass in situ with induced mobility of water and ions toward a capture electrode system

In situ jet mixing with air or water to create an inplace slurry reactor that could be manipulated to achieve physical, chemical, or biological processes for removal/degradation of VOCs

In situ application of electromagnetic or radiofrequency energy to heat the soil mass in place and volatilize VOCs

Injection of hydrogen peroxide during soil mixing by a dual auger system or by jetting, or application ex situ. VOCs are chemically oxidized, physically stripped, and/or biodegraded

Excavated soil is processed by thermal treatment during which VOCs are volatilized, captured, and/or destroyed

Similar to in situ process, except excavated soil is treated above ground in a tank or container

a The order of presentation in this table does not indicate technology priority or ranking. 


\subsubsection{Technology Evaluation and Ranking}

A rational process was used to evaluate and rank the candidate technologies to facilitate selection of a technology, or a set of technologies, and the approach for the Phase 2 demonstration. For this purpose, a method was employed that provided a format for developing objectives, listing alternatives, and weighing the alternatives against the objectives and against each other. The method is commonly referred to as the Kepner-Tregoe (K-T) method. A general description of the method is given below followed by a description of its use for this project.

The first step of the ranking process is to identify a team of professionals to participate in the evaluation process. Then, a consensus is developed by the evaluating team for the problem to be addressed. Next, a list of objectives to be achieved by the solution is generated. This list of objectives is then divided into those that absolutely have to be met (the "musts") and those that are desirable but not necessarily essential (the "wants"). Each of the wants is individually ranked in accordance with its importance, using a scale of 1 to 10.

The list of proposed solutions (in this case, eight different soil treatment technologies) is then drawn up, and the evaluation follows. Evaluation of the musts is done first. Only yes/no evaluations are required for the musts. Because these are the truly essential objectives, any alternative that fails to meet a must is normally rejected outright. Those that meet ali of the musts are carried on and evaluated against the wants.

Because the wants are items that do not provide clear rejection criteria, alternatives meeting all of the musts are rated against each want using a scale of 1 to 10. These values are multiplied by the importance ranking of each want to create a matrix of ratings. The sum of all ratings for each altcrnative is then obtained and forms the basis for a numerical evaluation of potentially successful alternatives against each other.

The alternative(s) with the highest score(s) is identified as the one which meets all required objectives (i.e., musts) and meets the other desired objectives (i.e., wants) to the greatest extent. The ratings matrix provides documentation of the strengths and weaknesses of each of the alternatives. If the resulting recommendation does not seem reasonable, the list of objectives or rankings can be reviewed to ensure that the scoring was done in an appropriate manner. Likewise, the documented matrix forms a structure for others to provide comment to the decision-making process.

For this project, a total of thirteen scientists and engineers participated in the evaluation team. The individuals involved represented a wide range of professional expertise and project perspectives. The evaluation team was made up of personnel from Chemical Technology, Environmental Sciences, and Analytical Chemistry, Environmental Restoration, and Central Engineering divisions, Waste R\&D Programs, and Central Waste Management (Table 5.2).

The consensus decision statement was:

Select a process(es) for demonstration to treat the X23IB unit soils for remoral or immobilization of VOCS to the specified levels: remove or destroy VOCS so residual soil concentration is less than I mg/kg; or immobilize the soil VOCs so concentrations in the leachate from TCLP tests are below U.S. EPA toxicity thresholds. In addition, the selected process(es:) should have a high probability of successs and be amenable to demonstration within a 5 -month period of time from aw'ard of contract. 
Table 5.2. Staff involved in the evaluation and ranking of candidate technologies for demonstration at the $\mathrm{X}-231 \mathrm{~B}$ site.

\begin{tabular}{ll}
\hline Staff & Affiliation \\
\hline M. I. Morris (Lead) & Chemical Technology Division, ORNL \\
R. L. Siegrist & Environmental Sciences Division, ORNL \\
T. L. Donaldson & Chemical Technology Division, ORNL \\
S. E. Herbes & Environmental Sciences Division, ORNL \\
A.V. Palumbo & Environmental Sciences Division, ORNL \\
C. M. Morrissey & Environmental Sciences Division, ORNL \\
R. A. Jenkins & Analytical Chemistry Division, ORNL \\
M. T. Harris & Chemical Technology Division, ORNL \\
J. H. Wilson & Chemical Technology Division, ORNL \\
C. P. McGinnis & Waste R\&D Program Office, Energy Systems \\
J. S. Watson & Environmental Restoration Division, Energy Systems \\
R. L. Jolley & Chemical Technology Division, ORNL \\
J. S. Baldwin & Central Waste Management, K-25 Site \\
\hline
\end{tabular}


Steps 2 through 4 of the ranking process are to (2) define the objectives, (3) divide the objectives into musts and wants, and (4) rank the wants. This was accomplished by issuing to the evaluation team a preliminary version of the decision statement and the demonstration objectives divided into musts and wants. Comments were requested on the objectives list, along with weightings of the wants. A team meeting was held to review the comments. The decision statement and list of objectives were discussed and revised along with the breakdown into musts and wants. The resulting decision framework is summarized in Table 5.3.

\subsection{RESULTS AND DISCUSSION}

The results of the screening and evaluation of the eight soil treatment technologies are presented in this section. Brief technology descriptions are followed by the results of the rational evaluation and ranking process.

\subsubsection{Technology Descriptions}

A synopsis of key technology features is provided in Table 5.4. Individual technology summary sheets prepared by project team members are given in Appendix D. These were prepared based on team member knowledge and experience, literature review, personal inquiries, and information provided by the technology vendors surveyed. Highlights of each candidate technology are provided below.

\subsubsection{In situ immobilization}

Stabilization/solidification involves intimately mixing contaminated soil with dry or fluid treatment chemicals to produce a solidified or stabilized end product. The special chemical blend, which is determined by treatability studies, will bind organics, inorganics, and radionuclides. In situ or ex situ methods can be used to mix the chemicals and soil.

Engineering tools such as augers and high-pressure liquid jets are used to mix chemical and contaminated soils in situ. Augers are especially useful in homogeneous soils where there are no buried solid objects.

The shallow soil mixing (SSM) technique uses a crane mounted auger to mix soils of varying moisture contents, ranging from dry solids to fluid sludge to depths of $30 \mathrm{ft}$ or deeper [13]. The mixing head is enclosed in a bottom-opened cylinder, allowing closed-system mixing of the waste for dust and volatile organic control. The bottom-opened cylinder is lowered into the waste, and the mixing blades are started while chemical or grout are introduced. The mixing blades mix through the total depth of the waste in an up and down motion. The headspace of the cylinder is kept at negative pressure to pull vapors or dust to the vapor treatment system. Upon completion, the blades are retracted inside the bottom-opened cylinder and the cylinder is removed. The cylinder is placed adjacent and overlapping the previous cylinder, and the process is repeated until all waste has been treated. Processing rates average approximately 1000 yard $3 / \mathrm{d}$. 
Table 5.3. Summary of the decision framework used in evaluating candidate technologies for demonstration at the X-231B site.

\section{Decision framework}

\section{OBJECTIVES:}

1. Remove or immobilize VOCs to the specified levels as specified in the decision statement.

2. Complete process installation and operation within a 5 month period of time.

3. Meet all applicable site, Energy Systems, DOE, and regulatory QA/QC and safety requirements.

4. Demonstrate that the reliability/operability/maintainability of the processing system is likely to be high.

5. Minimize secondary waste streams which require treatment and/or disposal by PORTS.

6. Minimize full-scale remediation costs: equipment installation, processing, and decommissioning; waste storage and final disposal; and site requirements.

7. Minimize occupational exposure of site workers and potential risks to health of the general public and to the environment during the demonstration.

8. Remove and/or destroy VOCs in preference to containment.

9. Ability of process to remove/destroy/immobilize non-VOC hazardous components such as heavy metals and radionuclides.

10. Demonstrate a process that has application at other DOE problem sites.

MUSTS:

1. The process must remove or immobilize VOCs to the specified levels.

2. The process installation and operation must be completed within a 5-month period of time.

3. Permits, quality assurance and safety requirements must be met.

- Permits (RD\&D, Air, NPDES, NEPA, EPA, OEPA)

- Quality assurance plan

- Safety assessment

\section{WANTS:}

1. An assurance that the reliability/operability/maintainability of processing system is sufficient to meet processing requirements.

2. Minimize secondary waste streams (solid liquid and gases) that require treatment and/or disposal by PORTS.

3. Minimize costs of full-scale remediation: equipment installation, processing, and decommissioning; waste storage and final disposal; and site requirements.

4. Minimize occupational exposure of site workers and potential risks to health of the general public and to the environment during the demonstration.

5. Remove and/or destroy VOCs in preference to containment.

6. Ability of process to remove/destroy/immobilize non-VOC hazardous components such as heavy metals and radionuclides.

7. Applicability of process to other similar DOE sites. 
Table 5.4. Summary of the key features of the candidate technologies evaluated.

\begin{tabular}{|c|c|c|c|c|}
\hline \multirow[b]{2}{*}{ Technology } & \multicolumn{4}{|c|}{ Technology attributes } \\
\hline & $\begin{array}{l}\text { Unit } \\
\text { process } \\
\text { features } \\
\end{array}$ & $\begin{array}{l}\mathrm{VOC} \\
\text { removal/ } \\
\text { destruction } \\
\text { mechanisms }\end{array}$ & $\begin{array}{l}\text { Effects on } \\
\text { non-VOC } \\
\text { contaminants } \\
\end{array}$ & $\begin{array}{l}\text { Development } \\
\text { status }\end{array}$ \\
\hline $\begin{array}{l}\text { In situ } \\
\text { immobilization }\end{array}$ & $\begin{array}{l}\text { Mixing and } \\
\text { injection of a } \\
\text { immobilization agent } \\
\text { with subsequent in } \\
\text { place soil } \\
\text { solidification }\end{array}$ & $\begin{array}{l}\text { Immobilization in } \\
\text { solid matrix. } \\
\text { Potential VOC } \\
\text { volatilization during } \\
\text { mixing and chemical } \\
\text { reactions }\end{array}$ & $\begin{array}{l}\text { Immobilization of } \\
\text { inorganic } \\
\text { contaminants }\end{array}$ & $\begin{array}{l}\text { Well-established for } \\
\text { inorganics. Some } \\
\text { questions remain for } \\
\text { organics }\end{array}$ \\
\hline $\begin{array}{l}\text { In situ air } \\
\text { stripping }\end{array}$ & $\begin{array}{l}\text { Mixing and injection } \\
\text { of hot air and/or } \\
\text { slcam with in situ air } \\
\text { stripping of VOCs }\end{array}$ & $\begin{array}{l}\text { Volatilization loss } \\
\text { during mixing and air } \\
\text { stripping. } \\
\text { VOC destruction by } \\
\text { off-gas treatment }\end{array}$ & $\begin{array}{l}\text { Some reduction in } \\
\text { semivolatile } \\
\text { organics. } \\
\text { No effect on } \\
\text { inorganics }\end{array}$ & $\begin{array}{l}\text { Developed and tested } \\
\text { at several sites, but } \\
\text { none identical to } \\
\text { PORTS }\end{array}$ \\
\hline $\begin{array}{l}\text { In situ } \\
\text { electrokinetics }\end{array}$ & $\begin{array}{l}\text { Application of } \\
\text { electrical energy to } \\
\text { the soil mass with } \\
\text { induced mobility of } \\
\text { water and ions toward } \\
\text { a capture electrode } \\
\text { system }\end{array}$ & $\begin{array}{l}\text { Electrokinetic } \\
\text { migration to capture } \\
\text { electrode and removal } \\
\text { for above ground } \\
\text { treatment }\end{array}$ & $\begin{array}{l}\text { Cations (e.g., heavy } \\
\text { metals) migrate and } \\
\text { can be removed }\end{array}$ & $\begin{array}{l}\text { Demonstrated at field } \\
\text { pilot scale but only } \\
\text { for inorganic ions }\end{array}$ \\
\hline $\begin{array}{l}\text { In situ jet } \\
\text { mixing slurry } \\
\text { reactor }\end{array}$ & $\begin{array}{l}\text { In situ jet mixing } \\
\text { with air or water to } \\
\text { create slurry reactor }\end{array}$ & $\begin{array}{l}\text { Reactor could employ } \\
\text { physical, chemical, } \\
\text { or biological } \\
\text { processes for removal } \\
\text { and/or degradation of } \\
\text { VOCs }\end{array}$ & $\begin{array}{l}\text { Reactor could be } \\
\text { designed to remove } \\
\text { and/or destroy non- } \\
\text { VOC contaminants }\end{array}$ & $\begin{array}{l}\text { Similar technology } \\
\text { used for } \\
\text { impoundment sludges } \\
\text { at full-scale. No } \\
\text { application for soil } \\
\text { materials }\end{array}$ \\
\hline $\begin{array}{l}\text { In situ } \mathrm{EM} / \mathrm{RF} \\
\text { heating }\end{array}$ & $\begin{array}{l}\text { Application of } \\
\text { electromagnetic or } \\
\text { radiofrequency energy } \\
\text { to heat the soil mass } \\
\text { in situ }\end{array}$ & Volatilization & $\begin{array}{l}\text { Some removal of } \\
\text { semivolatile organics }\end{array}$ & $\begin{array}{l}\text { Demonstrated at field } \\
\text { pilot scale at one site }\end{array}$ \\
\hline $\begin{array}{l}\text { In situ (ex situ) } \\
\text { hydrogen } \\
\text { peroxide } \\
\text { treatment }\end{array}$ & $\begin{array}{l}\text { Injection of hydrogen } \\
\text { peroxide during soil } \\
\text { mixing by a dual } \\
\text { auger system or by } \\
\text { jetting, or application } \\
\text { ex situ }\end{array}$ & $\begin{array}{l}\text { VOCs are chemically } \\
\text { oxidized, physically } \\
\text { stripped and/or } \\
\text { biodegraded }\end{array}$ & $\begin{array}{l}\text { Some potential } \\
\text { removal and/or } \\
\text { degradation of } \\
\text { semivolatile organics }\end{array}$ & $\begin{array}{l}\text { Commercially } \\
\text { available for ex situ } \\
\text { applications. In situ } \\
\text { treatment of soils is } \\
\text { novel }\end{array}$ \\
\hline $\begin{array}{l}\text { Ex situ thermal } \\
\text { treatment }\end{array}$ & $\begin{array}{l}\text { Excavated soil is } \\
\text { processed by low } \\
\text { temperature treatment }\end{array}$ & Volatilization & None & $\begin{array}{l}\text { Commercially } \\
\text { available technology }\end{array}$ \\
\hline $\begin{array}{l}\text { Ex situ } \\
\text { immobilization }\end{array}$ & $\begin{array}{l}\text { Similar to in situ } \\
\text { process, except } \\
\text { excavated soil is } \\
\text { treated above ground }\end{array}$ & $\begin{array}{l}\text { Immobilization in } \\
\text { solid matrix. } \\
\text { Potential VOC } \\
\text { volatilization during } \\
\text { mixing and chemical } \\
\text { reactions }\end{array}$ & $\begin{array}{l}\text { Immobilization of } \\
\text { inorganic } \\
\text { contaminants }\end{array}$ & $\begin{array}{l}\text { Well-cstablished for } \\
\text { inorganics. Some } \\
\text { questions remain for } \\
\text { organics }\end{array}$ \\
\hline
\end{tabular}


Jet mixing or chemically churned pile jet grouting (CCP) is the use of high-pressure $(4,000-6,000$ psi) liquid jets to cut geometric shapes in soils, mixing the soil with a chemical blend that occupies the resulting shape [14]. Jet mixing is advantageous when the contaminated soil is heterogeneous (i.e., containing buried solid objects) and compact. Processing rates are approximately 100 to 200 $\operatorname{yard}^{3} / d$.

In jet mixing, the chemical blend exiting the jets at high velocity impinges on the soil and shatters it for some distance from the jets. At the same time, the chemical blend is uniformly and very intimately mixed with the soil particles. As the jets are moved upward, a nearly cylindrical column of treated soil is generated. The diameter of the column is a function of soil strength, soil composition, jetting pressure, jetting time, jet nozzle diameter, cement density, and rotational speed. Typical column diameters range from 0.6 to $1.2 \mathrm{~m}(2$ to $4 \mathrm{ft})$ and larger. Therefore, columns of a set diameter can be designed and predictably placed for a given soil condition and design requirement.

\subsubsection{In situ hot-air or steam stripping}

This technology involves a mobile treatment unit that is designed to drill through unsaturated or saturated zones of contamination while simultaneously injecting steam, hot air, or solidification or oxidizing agents [15-18]. One of the primary vendors for this technology is Toxic Treatments (USA), Inc. (Detoxifier system). The system configuration consists of three main components: (1) a process tower, (2) a control system, and (3) a chemical treatment train. The process tower is essentially a drilling rig composed of dual, overlapping, counter-rotating, 5-ft-diam, hollow augers designed to penetrate to approximately $30 \mathrm{ft}$ while simultaneously injecting steam, hot air, etc., into the subsurface. The steam and/or other remediation agents are added to and mixed with the soil at increasing depths as the drilling proceeds. Treatment is achieved in overlapping blocks with an effective surface area of $27 \mathrm{ft}^{2}$ that are covered by a shroud that is under vacuum to contain the stripped contaminants and direct them to the chemical process train. The control system includes process monitoring and control through the use of on-line analytical instrumentation such as flame jonization detectors (FIDs) for total hydrocarbon analysis, a GC for specific organic analysis, and temperature and depth probes. This instrumentation allows for real-time analysis of treatment progress and allows for equipment adjustment as necessary. The chemical process train includes a condenser for liquid contaminant recovery, a carbon adsorption system for removal of contaminant vapors, a reheat system for heating and recycling of injected air, and a feed system to supply agents (steam, etc.) to the drill head assembly.

There have been at least four independently evaluated tests of the Detoxifier system. Three tests were co. Iucted at a site in San Pedro, California, (two conducted as part of the EPA SITE program and one under the direction of the California Department of Health Services Toxic Substances Control Division), and the fourth was conducted at a petroleum hydrocarbon contaminated site in Carson, California, and evaluated by Tetra Tech, Inc. [15-18]. This fourth test was done by the original manufacturers of the technology, namely Alternative Technologies for Waste, Inc. (ATW) and Calweld. Inc.

At the San Pedro site over $8,0(00$ yards of soil was contaminated with up to $12,000 \mathrm{ppm}$ of chlorinated hydrocarbons plus other volatiles and semivolatiles from a few ppm to $50,000 \mathrm{ppm}$. Up to $99 \%$ removal of volatiles from the soil was achieved (efficiencies of removal ranged from 54 to $99+\%$ ). Semivolatiles were removed with efficiencies ranging from 7 to $98 \%$. Post-treatment concentrations of the VOCs averaged 57,53 , and $71 \mathrm{ppm}$, respectively, in the three tests. For the SVOCs, 920 and $490 \mathrm{ppm}$ remained after completion of two of the tests. 
At the Carson site, when the total petroleum hydrocarbon (TPH) concentration was less than or equal to about $1000 \mathrm{ppm}$, removal efficiencies were 75 to $90 \%$ for a 15 -ft soil column, with an average treatment time of $47 \mathrm{~min}$ per column. When TPH was greater than $10,000 \mathrm{ppm}$, removal efficiencies were 90 to $95 \%$ on a 20 -ft column at 78 min per column.

Treatment time with the Detoxifier system is a function of four factors: type of contaminant, depth of contamination, the soil matrix, and the cleanup standard. Treatment is not limited by soil particle size, initial porosity, chemical concentration, or viscosity. Steam is injected at 450 to $475^{\circ} \mathrm{F}$ and $380 \mathrm{psi}$, and the soil temperature reaches 160 to $175^{\circ} \mathrm{F}$.

The mobility of the system makes it usable at a wide variety of sites and enables rapid start-up. The company currently has one complete system operational, and two more are being constructed. Waste streams produced by the Detoxifier system include off-gas that is contained by the shroud and routed through a scrubber for particulate removal and through activated carbon for organic removal. The off-gas is reheated after cleanup and reinjected through the hollow drill rods to provide a closed loop. The contaminant saturated steam is condensed and is utilized for solvent recovery or stored for disposal. Toxics Treatments is currently considering the use of incineration for treating the liquid waste stream. Air emissions as measured by EPA during the SITE program test were only $0.0729 \mathrm{lb} / \mathrm{d}$ for the four blocks treated. For successful operation, the site must be graded to $1 \%$ and must be greater than 0.5 acres. The area must be capable of supporting the unit's weight, and all underground obstructions greater than 12-in. diam must be removed. Treatment costs, typically $\sim \$ 300 / \mathrm{yd}^{3}$ when $3 \mathrm{yd}^{3}$ are treated per hour, is strongly dependent on soil type and contaminant volatility.

A system similar to the Detoxifier was developed by Geo-Con, Inc. [10]. This is a deep soil mixing system (DSM) that consists of a series of hydraulically driven mixing paddles and augers. Steam or other agents can be fed to the subsurface through a hollow shaft. It is not clear if this system has been tested at a contaminated site.

Other in situ steam stripping systems generally consist of steam injection coupled with vacuum extraction (SIVE) and do not involve simultaneous drilling and injection. One such system, developed by Heijmans Milieutechiek B.V. in the Netherlands, was tested at several locations in Europe with mixed results. The system worked well in very sandy soils and not so well in clay. Overall, the performance of the system was described as poor.

Another SIVE system has been tested by Solvent Services, Inc. (SSI), as part of the SITE program at the SSI site in San Jose, California. This site served as an industrial solvent and acid treatment facility since 1973. A variety of VOCs are found in the soil and groundwater and originated from underground storage tanks (USTs) and spills. The site is on the state Superfund list and is mainly contaminated with xylenes, ethylbenzene, 1,2-dichlorobenzene, TCA, TCE, perchloroethylene $(\mathrm{PCE})$, and acetone at concentrations up to $10,(0) 0 \mathrm{ppm}$. Contamination is confined to the top $20 \mathrm{ft}$ of soil beneath a concrete pad.

The technology of in situ hot air or steam stripping, as exemplified by the Toxic Treatments Detoxifier system, seems well suited to deal with the VOC soil contamination at PORTS. To date, the system has been tested with low-permeability soils contaminated with organics at higher levels than found at PORTS. Although the final soil concentrations have not been reduced to less than 1 $\mathrm{mg} / \mathrm{kg}$, this may be attributed to the initially high levels. Given adequate treatment time, levels below $1 \mathrm{mg} / \mathrm{kg}$ can reasonably be expected. The potential for injecting immobilizing agents in addition to hot air or steam provides an added benefit. Tests to date have shown the Detoxifier system to be mechanically reliable and of low environmental impact. There has been some concern over the possible mobilization of nonstrippable contaminants. This concern should be addressed at PORTS because of the saturated sand deposit that underlies the contaminated clays. 


\subsubsection{In situ electrokinetics}

Electrokinetics has long been demonstrated to be a viable process for soil stabilization and dewatering associated with construction practices [19]. More recently, electrokinetir processes have been considered for application to hazardous waste sites for removal of contaminants from wet soils with low permeabilities |19-21|.

Several electrokinetic phenomena can be involved. Electroosmosis is the process by which soil water is moved from an anode to a cathode. Electrophoresis involves the movement of particles under the influence of an electrical field. Electrolysis involves the movement of ions and ion complexes. An electrokinetic installation consists of an electrode array placed in the soil with the application of a constant, Iow DC current. Research has shown that electrokinetic processes have the potential for removing certain types of hazardous substances from soils. Strongly polar substances such as heavy metals are particularly amenable to this treatment.

At least one technology vendor (Geokinetics, The Netherlands) has demonstrated the capability of this technology in field pilot-scale applications at sites contaminated with heavy metals. Although electrokinetics is a promising innovative alternative for in situ soil treatment, its application at a site such as X-231 B is questionable given the principal contaminants being VOCs. Further research and development is needed along with pilot-scale demonstrations for the removal of organic compounds $|19|$.

\subsubsection{In situ slurry jet reactor}

The concept of an in situ slurry jet reactor was considered as a novel approach to remediation of the site. The jet mixing could be accomplished with the use of high-pressure fluids such as air or water. Given the fine texture of the subsurface materials and water contents approaching the liquid limit, particularly at depth, fluidizing small areas of the site was considered potentially feasible. If jet mixing of the soil in situ could be accomplished, then various processes could be employed to remove, destroy, or immobilize the VOCs. However, this process has not been developed to any degree, and implementation at POR'TS X-231B would require considerable research and development.

\subsubsection{In situ $\mathrm{E} / \mathrm{M} / \mathrm{RF}$ soil heating}

In situ soil heating using electromagnetic or radiofrequency (RF) energy is an emerging technology for in situ remediation of VOC contaminated soil 122,231 . This process combines ohmic and dielectric mechanisms to heat the contaminated soil in situ. This is achieved by inserting tubular electrodes into the contaminated soil or by laying horizontal electrodes over the surface. The electrodes can be excited by radiofrequency energy, which in turn heats the soil. The energy required per ton of soil treated is approximately 30 to $100 \mathrm{kWh}$. The volatile contaminants must vaporize and be transported up to the ground surface, where they can be captured within a cover over the treatment zone. The RF technique is reportedly effective on contaminants with a boiling point less than $-3(x)$ 10 $40(0) \mathrm{C}$.

The technology was developed at the IIT Research Institute in Chicago. Originally developed for removal of fuel from tar sands and oil shale, the technique was adapted to site remediation. A pilot-scale test was conducted at a U.S. Air Force Base in Wisconsin where $\sim 50,(0)()$ gal of jet fuel 
had leached into sandy soil. During a $12-d$ test period, over $99 \%$ removal of VOCs was achieved within a $500 \mathrm{ft}^{3}$ treatment zone.

IIT reportedly signed an exclusive licensing agreement with Weston Services, Inc., a remediation company wholly owned by Roy F. Weston, Inc. The licensing agreement was allowed to lapse during 1990 after Weston discovered the costs of the process were prohibitive for the application and market they had originally envisioned (i.e., gasoline stations) [23].

\subsubsection{In situ / ex siłu hydrogen peroxide treatment}

Hydrogen peroxide has a long history of application in the waste management industry, particularly for wastewater treatment. It has also been used for removal of organic clogging materials from the infiltration surfaces of wastewater land treatment units. More recently, it has seen application for removal of diesel and other fuels from contaminated soils $[24,25]$. Much of this work has been conducted ex situ, but the application of the process in situ appears feasible as well.

One ex situ hydrogen peroxide process is known as the Chemical Oxidation Treatment Process $[24,25]$. It involves excavating the soil, loading the soil into a hopper that is under vacuum, and adding peroxide and an oxidation enhancer to oxidize the organics. The treated waste is returned to the excavated area. The off-gas is passed through carbon filters to remove VOCs. Approximately 100 sites containing TCE have been treated by this method. VOC levels have been easily reduced below $1 \mathrm{mg} / \mathrm{kg}$. Typical processing rates are $100 \mathrm{yd}^{3} / \mathrm{d}$.

In terms of the processing rates (i.e., completing the demonstration within the allotted time) and meeting the primary objective of immobilizing or removing VOCs to desired levels, ex situ peroxide treatment looks promising. It has been used to successfully treat soils contaminated with VOCs $[24,25]$. It would appear that the combination of using hydrogen peroxide with an auger or jet mixing device would provide a powerful in situ method for treating organic contaminated soils. Most vendors of soil mixing technologies have indicated that their systems are designed to handle a wide range of treatment chemicals. An off-gas treatment system would be required to prevent the uncontrolled release of VOCs to the atmosphere.

\subsubsection{Ex situ thermal treatment}

Ex situ thermal treatment of soils is a well-proven process for removal of VOCs from contaminated soils [10-12,23]. It involves excavation and on-site thermal desorption of VOCs. The technology is commercially available and has been demonstrated in several full-scale remediation projects. Potential limitations at X-231B would be the fine textured soil material and excavation of contaminated soil to the desired depth, particularly because of the shallow water table condition.

\subsubsection{Ex situ immobilization}

Excavation is sometimes required when intimate mixing of the soil and chemicals is not possible because of the nature of the soil or the presence of buried solid objects. Excavation can be done by a backhoe or engineering tolls specially designed for jet grouting.

In backhoe operations for the treatment of VOC-contaminated soils, the excavated soil is rapidly placed in a hopper and mixed with a chemical blend to bind the contaminants. The waste is 
returned to the excavated area and allowed to solidify. Typical processing rates are approximately $1000 \mathrm{yd}^{3} / \mathrm{d}$.

Engineering tools specially designed for jet grouting such as Triple System Jet Grouting, use highpressure water and air $(4,000)$ to $6,00() \mathrm{psi})$ to excavate the soil by bringing the returns to the surface, which is enclosed to prevent escape of VOCs to the atmosphere [26]. The soil is treated by suitable technique, mixed with chemical blend, and returned to the excavated area to solidify. Processing rates are approximately 200 yard $^{3} / \mathrm{d}$.

Jet grouting devices have not been used to treat VOCs; however, the remediation of a phenolcontaminated site has been achiever by this technique [26]. 'The soil was excavated by the triple-jet grouting engineering tool, washed in an enclosed area to extract the phenols, and returned to the excavated area for solidification.

\subsubsection{Technology Vendors}

A request for information was distributed to a selected number of vendors (about 30 ) known or suspected to provide one or more of the candidate technologies. The technology vendors that responded to the request for information (see Appendix $\mathrm{C}$ ) are summarized in Table 5.5. Detailed information provided by the vendors was disseminated to the project technical team and included in the evaluation and screening process of the candidate technologies. Many of the vendors requested that the information they provided not be published, hence the completed vendor survey forms are not included in this report.

As summarized in Table 5.5, while the candidate technologies were not explicitly mentioned in the vendor request for information (Appendix $C$ ), most of them were independently identified and proposed by the technology vendors contacted. Only the in situ slurry jet reactor and peroxide stripping processes were not among those proposed by the vendors.

\subsubsection{Technology Evaluation and Ranking}

The final weights assigned to each of the seven technology wants were analyzed to determine the central tendency and deviation (Table 5.6). As summarized in Table 5.6 and illustrated in Fig. 5.1, there was wide variation in the weights assigned to the different wants, although there was a central tendency for each. Recognizing the compliance driven, success orientation of the contemplated demonstration, the greatest average weight (8.53) and least variation between team members was for want No. 1, assurance of process reliability. In contrast, the lowest weight and much variation was associated with want No. 6, ability of the process to handle non-VOC contaminants. 
Table 5.5. Summary of vendors responding by candidate technology or process category. a

\begin{tabular}{|c|c|c|c|c|c|c|c|c|c|}
\hline \multirow[b]{2}{*}{$\begin{array}{l}\text { Technology } \\
\text { vendor }\end{array}$} & \multicolumn{9}{|c|}{ Technology or process } \\
\hline & $\begin{array}{l}\text { In Situ } \\
\text { Immob. }\end{array}$ & $\begin{array}{l}\text { In Situ } \\
\text { Air or } \\
\text { Steam } \\
\text { Strip. }\end{array}$ & $\begin{array}{l}\text { In Situ } \\
\text { Electro- } \\
\text { Kinctics }\end{array}$ & $\begin{array}{c}\text { In Situ } \\
\text { Slurry } \\
\text { Jet } \\
\text { Reactor }\end{array}$ & $\begin{array}{l}\text { In Situ } \\
\text { EM/RF } \\
\text { Heating }\end{array}$ & $\begin{array}{l}\text { In Situ } \\
\text { Peroxide } \\
\text { Treat. } \\
\end{array}$ & $\begin{array}{l}\text { Ex Situ } \\
\text { Thermal } \\
\text { Treat. }\end{array}$ & $\begin{array}{l}\text { Ex Situ } \\
\text { Immob. }\end{array}$ & Other \\
\hline AWD Technologies & & $\sqrt{ }$ & $\sqrt{ }$ & & & & & & $\begin{array}{c}\sqrt{ } \\
(2) \underline{b}\end{array}$ \\
\hline $\begin{array}{l}\text { Chemfix Environmental } \\
\text { Services, Inc. }\end{array}$ & & & & & & & & $\sqrt{ }$ & \\
\hline $\begin{array}{l}\text { Chem-Nuclear } \\
\text { Environmental Services, } \\
\text { Inc. }\end{array}$ & & & & & & & $\sqrt{2}$ & & \\
\hline Ecova & & & $\sqrt{n}$ & & & & $\sqrt{3}$ & & $\sqrt{3}$ \\
\hline Geokinetics & & & $\sqrt{ }$ & & & & & & \\
\hline IIT Research Institute & & & & & $\sqrt{ }$ & & & & \\
\hline $\begin{array}{l}\text { IM-Tech (formerly } \\
\text { HAZCON) }\end{array}$ & $\sqrt{ }$ & & & & & & & $\sqrt{ }$ & \\
\hline IT Corporation & $\sqrt{1}$ & - & & & & & $\sqrt{ }$ & & \\
\hline $\begin{array}{l}\text { International Waste } \\
\text { Technologies, Inc. }\end{array}$ & $\sqrt{ }$ & & & & & & $\sqrt{ }$ & & \\
\hline NRT Corporation & & & & & & & $\sqrt{ }$ & & \\
\hline Phonix Environment & & & & & & & & & $\sqrt{ }$ \\
\hline Qualtec, Inc. & & & & & & & & $\sqrt{ }$ & \\
\hline $\begin{array}{l}\text { Recycling Sciences } \\
\text { International, Inc. }\end{array}$ & & & & & & & $\sqrt{ }$ & & \\
\hline Roy F. Weston, Inc. & & $\sqrt{3}$ & & & & & $\sqrt{ }$ & & $\sqrt{1}$ \\
\hline $\begin{array}{l}\text { Separation and Recovery } \\
\text { Systems, Inc. }\end{array}$ & & & & & & & $\sqrt{ }$ & $\sqrt{ }$ & \\
\hline $\begin{array}{l}\text { Toxic Treatrnents } \\
\text { (USA), Inc. }\end{array}$ & & $\sqrt{ }$ & & & & & & & \\
\hline Wastech, Inc. & & & & & & & & $\sqrt{ }$ & \\
\hline $\begin{array}{l}\text { Westinghouse Electric } \\
\text { Corporation }\end{array}$ & & & & & & & $\sqrt{ }$ & & $\begin{array}{l}\sqrt{ } \\
\text { (2) }\end{array}$ \\
\hline
\end{tabular}

a Refer to Appendix $\mathrm{C}$ for an example of the vendor survey information request.

b Number in parenthesis equals the number of "other" technologies submitted by the vendor. 
Table 5.6. Summary of weighting values used for each of the technology "wants".

\begin{tabular}{|c|c|c|c|c|c|c|}
\hline & \multirow[b]{2}{*}{ Technology "want" } & \multicolumn{5}{|c|}{ Evaluation "want" weighting value statistics a } \\
\hline & & No. & Average & Std. Dev. & C.V. & Range \\
\hline 1. & $\begin{array}{l}\text { Assurance of process } \\
\text { reliability, operability and } \\
\text { maintainability }\end{array}$ & 13 & 8.54 & 1.51 & 0.18 & 5 to 10 \\
\hline 2. & $\begin{array}{l}\text { Minimize secondary waste } \\
\text { streams requiring PORTS } \\
\text { disposal }\end{array}$ & 13 & 6.69 & 1.65 & 0.25 & 4 to 9 \\
\hline 3. & $\begin{array}{l}\text { Minimize full-scale remediation } \\
\text { costs }\end{array}$ & 13 & 7.15 & 2.48 & 0.35 & 3 to 10 \\
\hline 4. & $\begin{array}{l}\text { Minimize occupational } \\
\text { exposure and public risk } \\
\text { during demonstration }\end{array}$ & 13 & 6.15 & 2.64 & 0.43 & 2 to 10 \\
\hline 5. & $\begin{array}{l}\text { Ability to :emove/destroy } \\
\text { VOCs vs in-place containment }\end{array}$ & 13 & 6.23 & 3.00 & 0.48 & 2 to 10 \\
\hline 6. & $\begin{array}{l}\text { Ability to handle non-VOC } \\
\text { hazardous contaminants too }\end{array}$ & 13 & 4.38 & 1.76 & 0.40 & 2 to 7 \\
\hline 7. & $\begin{array}{l}\text { Applicability of process to } \\
\text { other DOE sites }\end{array}$ & 13 & 5.69 & 2.10 & 0.37 & 2 to 10 \\
\hline
\end{tabular}

a Refer to Fig. 5.1 for a graphical illustration of the data tabulated. Refer to Appendix E for further details. 


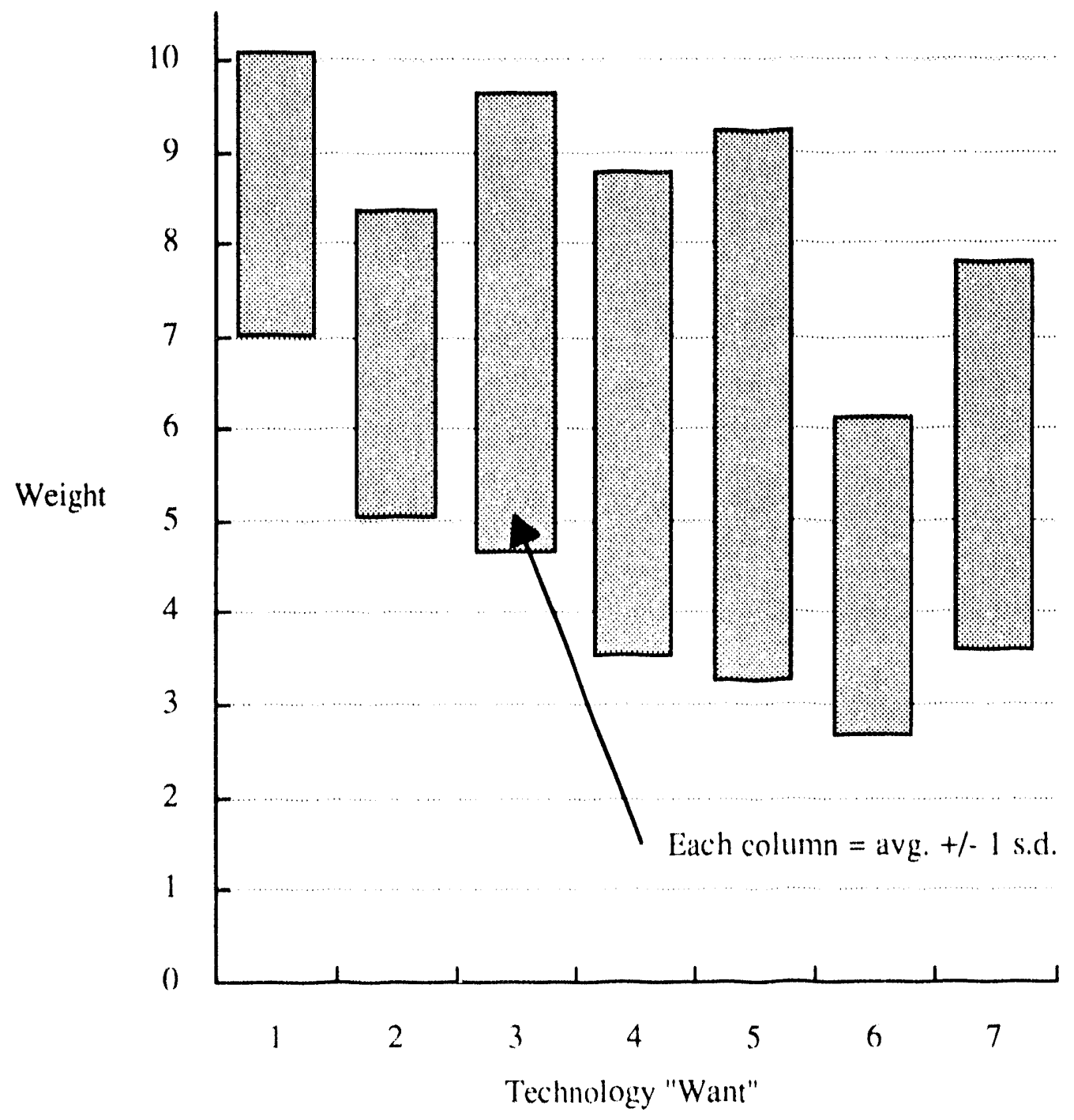

Technolog. "Want"

1. Assurance of process reliability, operability, and maintainability

2. Minimize secondary waste streams requiring PORTS dispossal

3. Minimize full-scale remediation costs

4. Minimize oxcupational exposure and public risk during demonstration

5. Ahility 10 remove/destroy VOC's vs in-place containment

6. Ability to handle non-VOC hazardous contaminants 100

7. Applicability of process to other DOE sites

Fig. 5.1. Graphical illustration of the weightings assigned to each of the technology "wants". 
Each of the 13 evaluation team members scored each of the wants for each of the candidate technologies. The results of this process are summarized in Table 5.7 and Fig. 5.2. The detailed scoring sheets may be found in Appendix E. As indicated in Table 5.7, the technologies were ranked such that there were two distinctly different groupings.

The five top-ranked technologies and their respective scores were:

- in situ immobilization (331),

- ex situ immobilization (314),

- in situ air/steam stripping (309),

- ex situ thermal treatment (303), and

- in situ (ex situ) peroxide stripping (297).

Evaluated considerably lower were:

- in situ EM/RF heating (252),

- in situ slurry reactor (246), and

- in situ electrokinetics (230).

The total scores of the top-ranked group was judged to be sufficiently higher compared with the bottom-ranked group that the two groupings could be considered different. However, the differences in rankings between technologies within each of the two groupings were judged to be insignificant by the evaluation team, given the variation in weights assigned to each technology want and the variation in scoring of each want for each technology (see Table 5.6).

\subsubsection{Technology Demonstration Strategy}

The rational ranking process did not identify any single soil treatment technology that was clearly outstanding among the top-ranked group. Thus, it was necessary to further evaluate and consider the candidate soil treatment technologies and develop a strategy for the demonstration at PORTS. The results of the vendor survey and technology evaluation and ranking process were critically evaluated and discussed by the thirteen scientists and engineers on the evaluating team during two team meetings. This led to the development of a consensus regarding the strategy for the technology demonstration at PORTs X-231B.

The demonstration strategy was developed with two broad objectives in mind. First, it was desired to demonstrate an in situ technology because that appeared most favorable for application at PORTS. Moreover, demonstrating, testing, and evaluation of in situ technologies was deemed to offer greater benefits to advancing the state of practice. A second objective was to conduct the demonstration in such a way as to facilitate testing and evaluation of novel to relatively proven processes with capability to handle VOCs only as well as non-VOC contaminants.

The thirteen members of the technology evaluation team concurred that the demonstration strategy should consist of a deep soil mixing technology coupled with the injection of immobilization agents, hot air/steam, or hydrogen peroxide, either individually or in combination. This approach would permit demonstration, testing, and evaluation of the three top-ranked in situ processes and would include processes for immobilization as well as removal/destruction. It would offer the highest probability of success for regulatory compliance as well as provide the greatest breadth and depth of information to the scientific and engineering community. 
Table 5.7. Summary of the rank scoring for each want for each of the candidate technologies. a

\begin{tabular}{|c|c|c|c|c|c|c|c|c|c|}
\hline & \multirow[b]{2}{*}{ Technology want } & \multicolumn{8}{|c|}{ Soil treatment technology or process } \\
\hline & & $\begin{array}{l}\text { In situ } \\
\text { immob. }\end{array}$ & $\begin{array}{c}\text { In situ } \\
\text { air strip. }\end{array}$ & $\begin{array}{l}\text { In situ } \\
\text { electro- } \\
\text { kinetics } \\
\end{array}$ & $\begin{array}{l}\text { In situ } \\
\text { slurry } \\
\text { reactor } \\
\end{array}$ & $\begin{array}{l}\text { In situ } \\
\text { EM/RF } \\
\text { heating } \\
\end{array}$ & $\begin{array}{l}\text { In situ / } \\
\text { ex situ } \\
\text { peroxide }\end{array}$ & $\begin{array}{l}\text { Ex situ } \\
\text { thermal }\end{array}$ & $\begin{array}{l}\text { Ex situ } \\
\text { immob. }\end{array}$ \\
\hline 1. & $\begin{array}{l}\text { Assurance of } \\
\text { process reliability, } \\
\text { operability and } \\
\text { maintainability }\end{array}$ & 71.4 & 56.8 & 31.0 & 40.4 & 37.8 & 69.7 & 70.5 & 79.1 \\
\hline 2 . & $\begin{array}{l}\text { Minimize } \\
\text { secondary waste } \\
\text { streams requiring } \\
\text { PORTS disposal }\end{array}$ & 62.6 & 45.6 & 42.8 & 40.8 & 41.5 & 47.6 & 49.0 & 53.7 \\
\hline 3 . & $\begin{array}{l}\text { Minimize full-scale } \\
\text { remediation costs }\end{array}$ & 54.0 & 50.4 & 38.0 & 46.0 & 38.7 & 38.7 & 34.3 & 48.9 \\
\hline 4. & $\begin{array}{l}\text { Minimize } \\
\text { occupational } \\
\text { exposure and } \\
\text { public risk during } \\
\text { demonstration }\end{array}$ & 53.7 & 45.8 & 44.5 & 41.5 & 37.2 & 36.0 & 34.2 & 38.4 \\
\hline 5. & $\begin{array}{l}\text { Ability to } \\
\text { remove/destroy } \\
\text { VOCs vs in-place } \\
\text { containment }\end{array}$ & 2.4 & 56.1 & 18.9 & 12.4 & 54.9 & 50.7 & 59.0 & 4.7 \\
\hline 6. & $\begin{array}{l}\text { Ability to handle } \\
\text { non-VOC } \\
\text { hazardous } \\
\text { contaminants too }\end{array}$ & 39.6 & 12.0 & 31.4 & 32.3 & 8.6 & 14.6 & 13.8 & 42.1 \\
\hline 7. & $\begin{array}{l}\text { Applicability of } \\
\text { process to other } \\
\text { DOE sites }\end{array}$ & 47.6 & 42.0 & 23.0 & 32.5 & 32.5 & 39.2 & 42.0 & 46.5 \\
\hline & Total Score & 331.2 & 308.5 & 229.5 & 245.8 & 251.2 & 296.5 & 302.7 & 313.5 \\
\hline & Rank $(1=$ highest $)$ & 1 & 3 & 8 & 7 & 6 & 5 & 4 & 2 \\
\hline
\end{tabular}

a Refer to Fig. 5.2 for a graphical illustration of the data tabulated. 


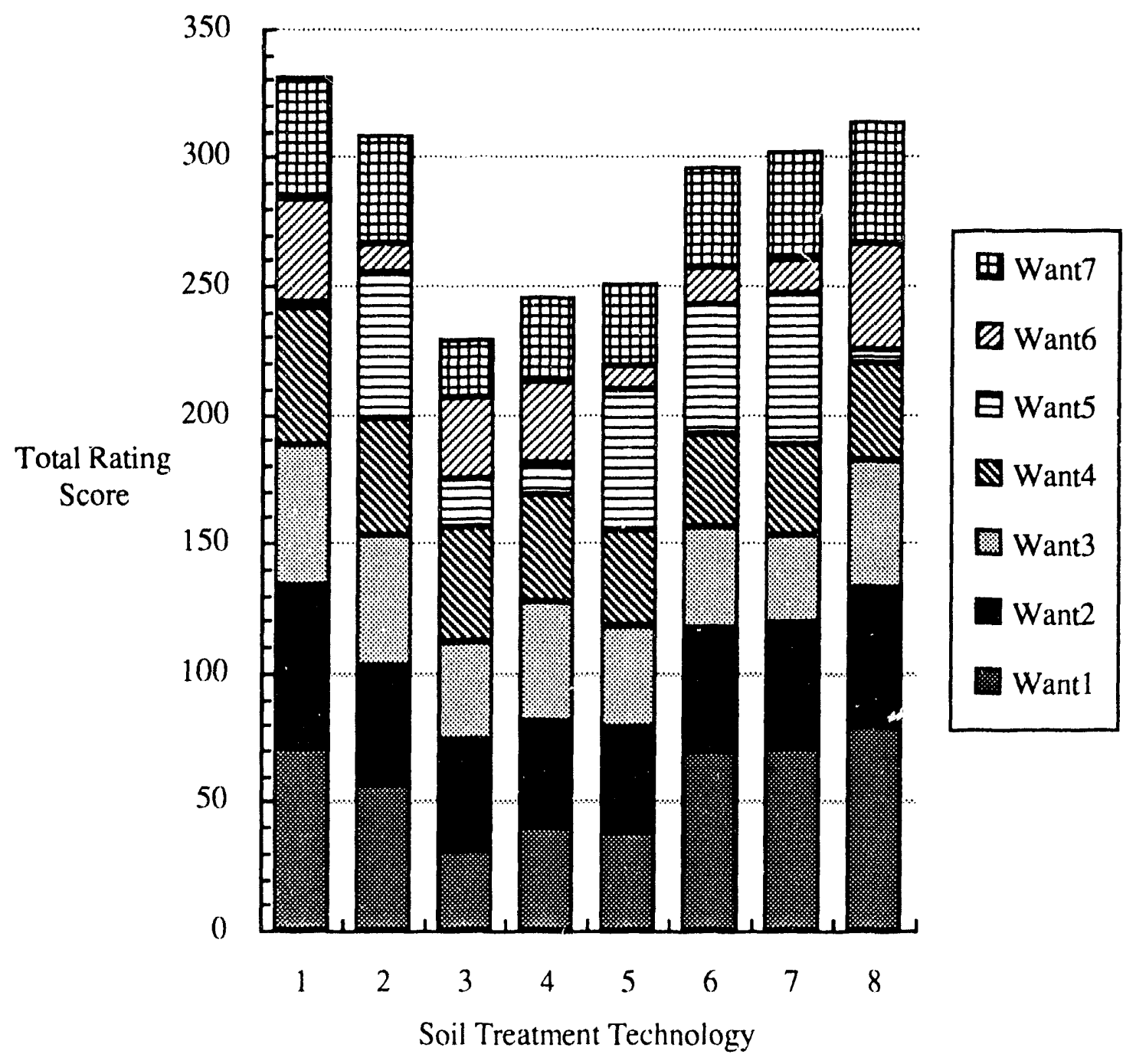

\footnotetext{
Soil Treatment Technology

1. in situ immobilization

2. In situ air/steam stripping

3. In situ electro-kinetics

4. In situ slurry reactor

5. In situ $E M / R F$ heating

6. In situ (ex situ) peroxide

7. Ex situ thermal desorption

8. Ex situ immobilization
}

\section{Technology "Want"}

1. Assurance of process reliability, operahility, and maintainability

2. Minimize secondary waste streams requiring PORTS disposal

3. Minimize full-scale remediation costs

4. Minimize occupational exposure and public risk during demonstration

5. Ability to remove/destroy VOCs vs in-place containment

6. Ahility to handle non-VOC havardous contaminants too

7. Applicability of process to other DOE sites

Fig. 5.2. Graphical illustration of the results of the tect nology evaluation and ranking. 


\subsection{TECHNOLOGY DEMONSTRATION, TESTING, AND EVALUATION}

Phase 2 of the X-231B project involves the implementation and conduct of technology demonstration, evaluation, and testing at the X-231B unit at PORTS. The key tasks envisioned and the approximate schedule are highlighted in Table 6.1. As currently envisioned (i.e., as of February 1991), Phase 2 of the project would begin in spring 1991 (e.g., April 1991) and continue during the subsequent 16 months. After 14 months, documentation regarding the methods, results, and conclusions of the demonstration would be produced for submittal to the OEPA. This information would be sufficiently comprehensive to facilitate a decision regarding full-scale soil remediation of the X-231B unit. A final research report would be prepared thereafter.

Table 6.1. Summary of Phase 2 activities and schedule for technology demonstration, testing and evaluation at PORTS X-231B.

\begin{tabular}{ll}
\hline Task & Key subtasks \\
\hline Task 1. Planning & Experimental design and planning \\
& Address/prepare permits and gain approval \\
& Address/prepare plans and gain approval \\
& Procurement (expression of interest, statement of work, RFP \\
preparation, solicitation, evaluation, contract award) \\
\hline Transport/fate/remediation model development \\
ORNL treatability and optimization \\
Vendor treatability and optimization \\
Analysis and report \\
\hline Site preparation \\
Mobilization and on-site setup \\
Performance monitoring and evaluation \\
Demonstration startup and operation \\
Demonstration termination \\
Demobilization and closeout \\
Data analysis and evaluation \\
Prepare documentation \\
Documentation to OEPA \\
Analysis and report \\
\end{tabular}

Task 4. Technology Transfer 


\subsection{CONCLUSIONS AND RECOMMENDATIONS}

The overall goal of this project was to select and successfully demonstrate a technology or technologies for effective treatment of the contaminated soils associated with the X-231B oil biodegradation unit at PORTS. The objectives of Phase 1 of the project were to define the problem domain and performance criteria; delineate the constraints affecting implementation of the technology demonstration; and identify, evaluate, and recommend one or more technologies judged to be capable of removing or immobilizing VOCs in the contaminated soils at the site. This report contains a discussion of the methods, results, and conclusions of the Phase 1 portion of the project.

Based on field investigations, laboratory analyses, and technology assessments, the following conclusions and recommendations have been reached.

1. The problem domain established for consideration of remediation technologies included the $X-231 \mathrm{~B}$ unit boundaries extending vertically to the Gallia Member at a depth of $\sim 25 \mathrm{ft}$. The target contaminants were VOCs, including all compounds on the EPA volatile organic hazardous substance list. The performance criteria for assessing capability of a technology included the ability to remove/destroy VOCs to a total residual soil concentration of less than $1 \mathrm{mg} / \mathrm{kg}$. Alternatively, the technology should be able to immobilize the VOCs so that VOCs in the leachate from a TCLP test would less than RCRA toxicity characteristic thresholds.

2. The soil/geologic material at X-231B site is contaminated with VOCs. The principal contaminants are TCE and TCA, with concentrations in the range of 100 to $7,000 \mu \mathrm{gg} / \mathrm{kg}$. VOC concentrations measured in 1990 were in the range of those measured several years earlier during previous studies, although the concentrations were somewhat lower, particularly in the saturated zone.

3. The subsurface conditions at X-231B pose challenges for effective soil remediation. This is because contaminants are dispersed in subsurface deposits characterized by low hydraulic permeabilities, fine-grained media (e.g., $>90 \%$ of particles with diameters $<50$ $\mu \mathrm{m})$, and wet-to-saturated soil conditions.

4. Several innovative/alternative technologies were identified that offer some capability for remediating the problem domain to the performance criteria established. Several of these technologies are commercially available but not well proven, particularly at sites similar to $\mathrm{X}-231 \mathrm{~B}$

5. A rational evaluation and ranking of alternative technologies identified two groups of technologies with relatively higher and lower rankings. Alternative technologies with some performance track record (e.g., immobilization or hot air/steam stripping) were ranked higher than more innovative technologies (e.g., RF heating and electrokinetics).

6. It was concluded that the Phase 2 technology demonstration, testing, and evaluation should consist of in situ deep soil mixing coupled with the injection of immobilization agents. hot air or steam, or hydrogen peroxide, either individually or in sequence. This approach would enable rigorous evaluation and comparison of in situ immobilization and removal/destruction processes. Conclusions regarding technology implementation, operation and maintenance, performance, and costs could then be utilized for full-scale remediation of the $X-231 B$ unit. 


\subsection{REFERENCES}

1. Morrison Knudsen Corporation Environmental Services Group. 1989. X-231B Oil Biodegradation Plot Closure Options Study. Report POEF-Z-4198. Prepared for the Portsmouth Gaseous Diffusion Plant, managed hy Martin Marietta Energy Systems, Inc., for the U.S. Department of Energy. November.

2. Morrison Knudsen Corporation Envitonmental Services Group. 1990. X-231B Oil Biodegradation Plot Closure Options Study. Report POEF-Z-4198, Revision 1. Prepared for the Portsmouth Gaseous Diffusion Plant, managed by Martin Marietta Energy Systems, Inc., for the U.S. Department of Energy. November.

3. Geraghty \& Miller, Inc. 1989. Groundwater Quality Assessment of Four RCRA Units Portsmouth Gaseous Diffusion Plant, Piketon, Ohio. Prepared for the Portsmouth Gaseous Diffusion Plant, managed by Martin Marietta Energy Systems, Inc., for the U.S. Department of Energy. May.

4. Advanced Sciences, Inc. 1988. Sampling Report for Piketon Oil Biodegradation Plot Project. ASI Project Number 661, Task 10. Oak Ridge, Tennessee, for Martin Marietta Energy Systems, Inc. January .

5. Geraghty \& Miller, Inc. 199(). RCRA Facilities Investigation Workplan for Quadrant I at the Portsmouth Gaseous Diffusion Plant, Piketon, Ohio. Dublin, Ohio.

6. U.S. Environmental Protection Agency. 1986. Test methods for evaluating solid waste. SW-846. U.S. Environmental Protection Agency, Office of Solid Waste and Emergency Response, Washington, D.C. 20460.

7. Methods of Soil Analysis: Part 1,1965 and Part 2. 1982. American Society of Agronomy, Madison, Wis.

8. Deep Subsurface Microbiology Program. 1990. U.S. Department of Energy. Idaho National Engineering Lab, NPR-E Technical Workplan 6.0, July.

9. Siegrist, R.L., and P.D. Jenssen. 1990. Evaluation of sampling method effects on volatile organic compound measurements in contaminated soils. Environ. Sci. \& Technol, 24(9): $1387-1392$.

10. U. S. Environmental Protection Agency. 1988. Technology Screening Guide for Treatment of CERCLA Soils and Sludges, EPA/540/2-88/(004. September.

11. U. S. Environmental Protection Agency. 1989. Assessment of International Technologies for Superfund Applications - Technology Identification and Selection, EPA/600/2-89/(017. May.

12. U. S. Environmental Protection Agency. 1989. The Superfund Innovative Technology Evaluation Program: Technology Profiles, EPA/540/5-89/(013. November.

13. Stiffey, J. R. 1991. GEO-CON, Inc., Pittsburgh, PA. personal communication to M. I. Morris, Oak Ridge National Laboratory. January.

14. Mote, J. 199(). Halliburton Environmental Technology, Houston, TX. personal communication to M.T. Harris, Oak Ridge National Laboratory. December 1990. 
15. Roy, K.A. 1990. In Situ Detoxifier, Hazmat World, Tower-Borner Publishing, Inc. April.

16. Treweek, G.P., and J. Wogec, 1988. Soil Remediation By Air/Steam Stripping. Proc. Fifth National Conference, Hazardous Wastes and Hazardous Materials. pp. 147-153.

17. Guenther, J. 1990. Toxic Treatments, Torrance, CA. personal communication to C. M. Morrissey, Oak Ridge National Laboratory. December.

18. dePercin, P. 1990. U.S. Environmental Protection Agency, Risk Reduction Engineering Laboratory, Cincinnati and Robbins, J., project engineer, State of California, personal communications to C. M. Morrissey, Oak Ridge National Laboratory. December.

19. Cabrera-Guzman, D., J.T. Swartzbaugh, and A.W. Weisman. 1990. The use of electrokinetics for hazardous waste site remediation. J. Air Waste Manage. Assoc. 40: 1670-1676.

20. Lageman, R., W. Pool, and G.A. Seffinga. 1990. Electro-reclamation: state-of-the-art and future developments. In: Contaminated Soil '90, Proceedings, Third International KfK/TNO Conference on Contaminated Soil, 10-14, 1990, Karlsruhe, FRG. Kluwer Academic Publishers, Boston.

21. Renaud, P.C. 1990. In situ extraction of contaminants from hazardous wastes by electroosmosis. In: Contaminated Soil '90, Proceedings, Third International KfK/TNO Conference on Contaminated Soil, 10-14, 1990, Karlsruhe, FRG. Kluwer Academic Publishers, Boston.

22. Roy, K.A. 1989. Electrifying soil cleanup. Hazmat World, Tower-Borner Publishing, Inc. July. pp. 14-15.

23. Nielson, R. 1990. Weston Services, Inc., Wesi Chester, Pa. personal communication to M. I. Morris, Oak Ridge National Laboratory, November.

24. Khan, K. 1990. ENSO TECH, Inc., Sunny Valley, CA. personal communication to M. T. Harris, Oak Ridge National Laboratory. December.

25. ENSOTECH, Inc. 1990. Promotional brochure. Sunny Valley, CA.

26. Ringen, A. R. 1990. Hayward Baker, Inc. personal communication to M. T. Harris, Oak Ridge National Laboratory. December. 


\subsection{APPENDICES}


APPENDIX A. SITE CHARACTERIZATION SOIL BORING LOGS 
OII Well Summary Information

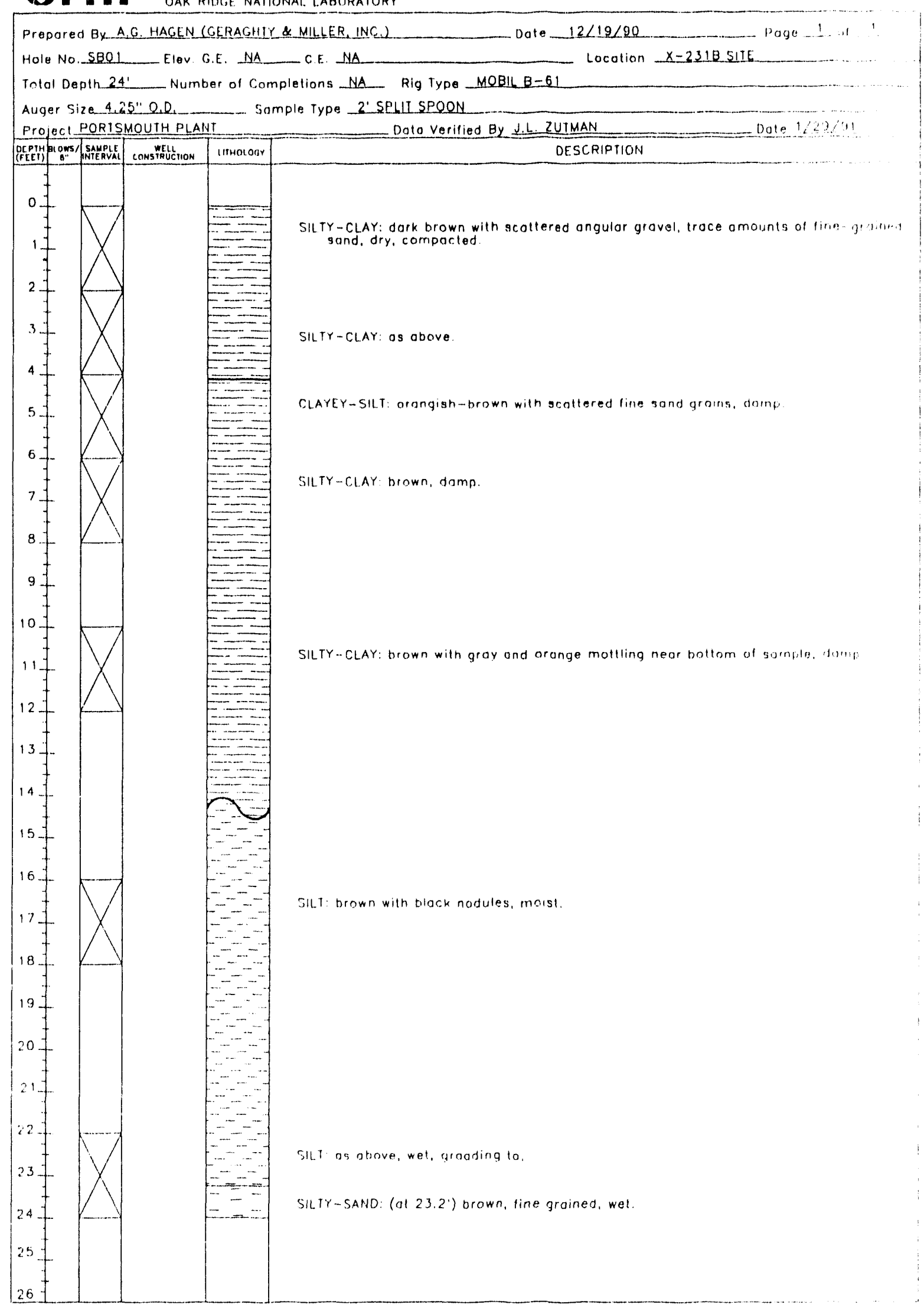


QII oak ridge national laboratory

Well Summary Information

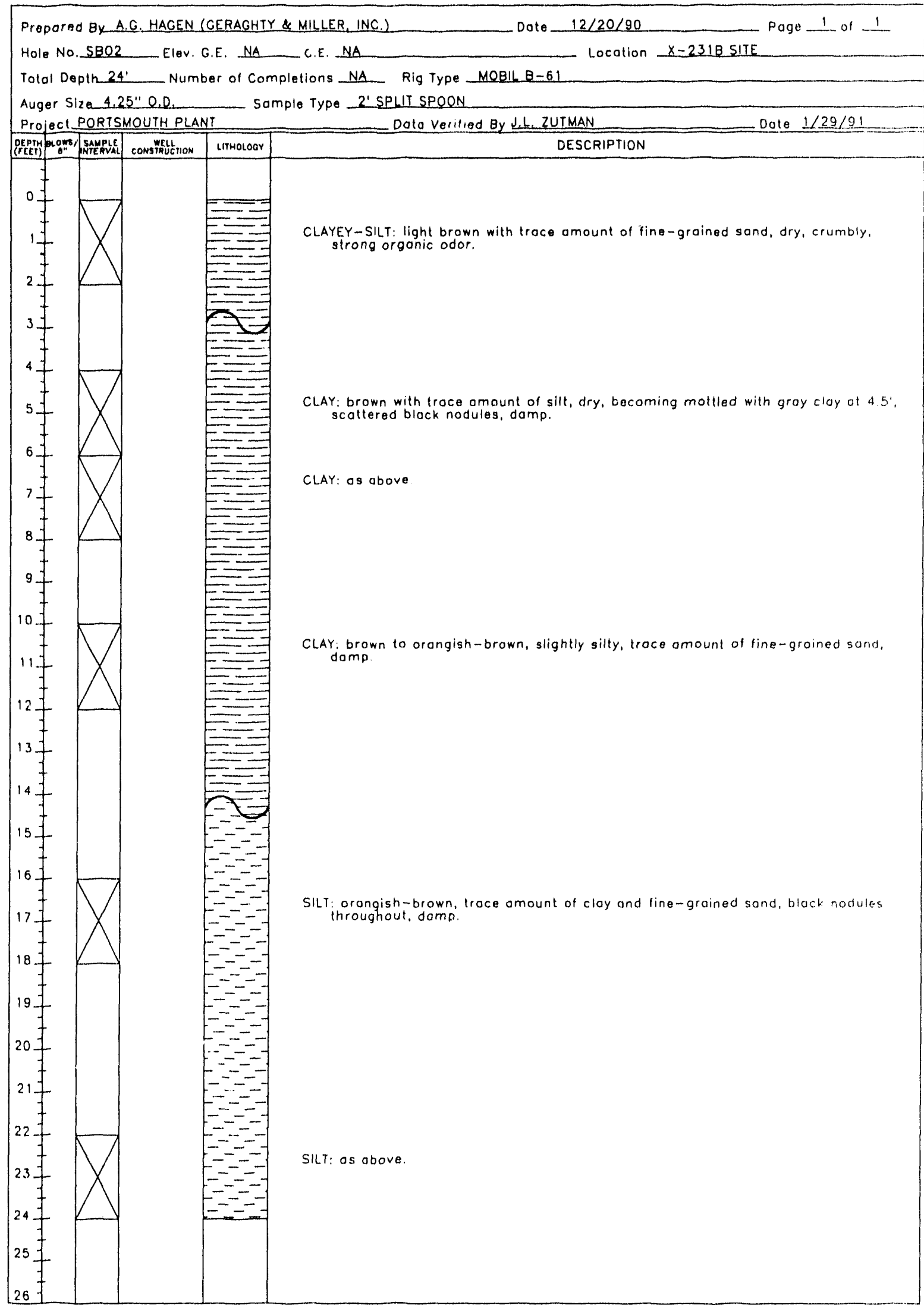


0111 oak ridge national laboratory

Well Summary Information

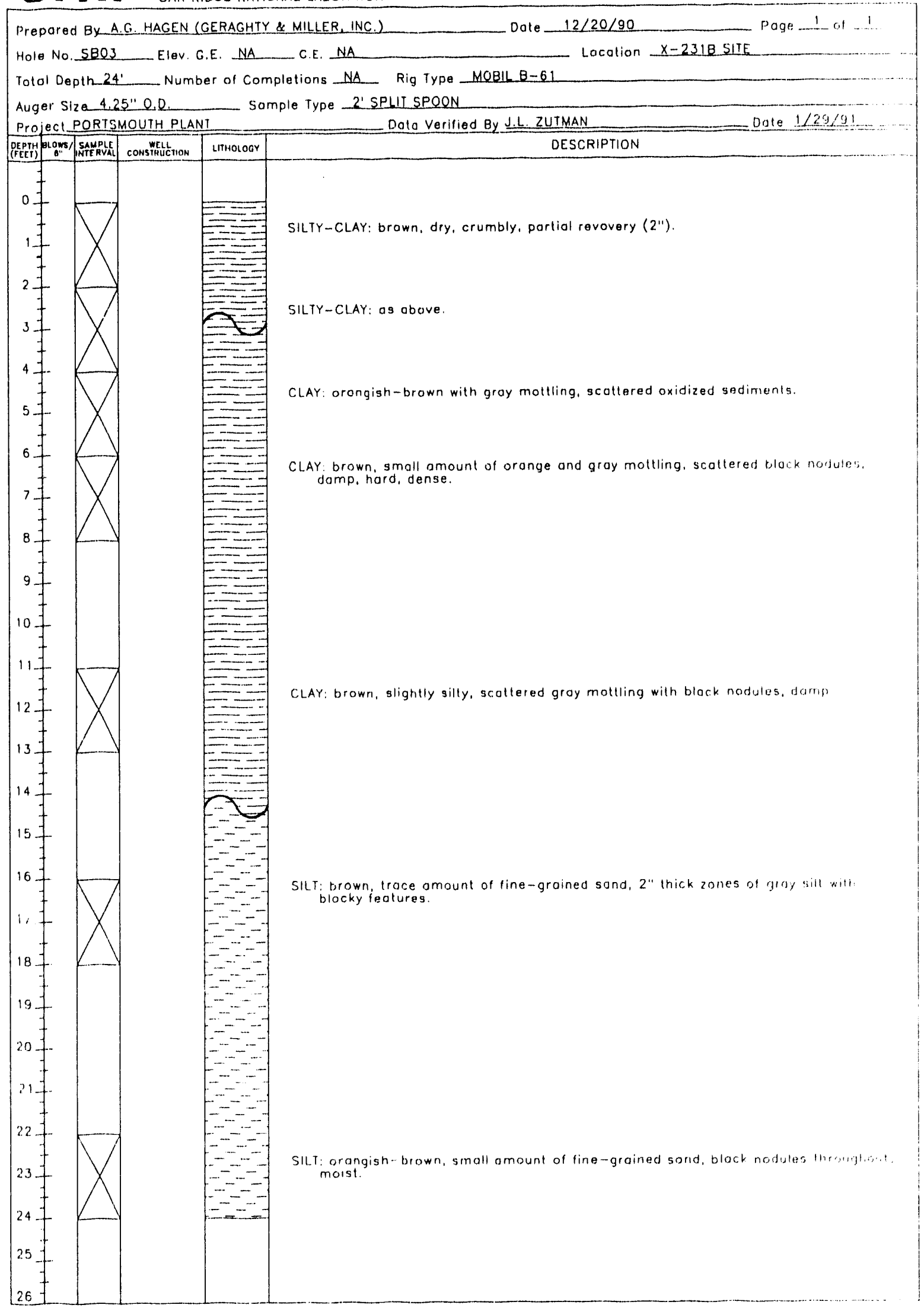


APPENDIX B. SOIL VOC ANALYSES DATA 


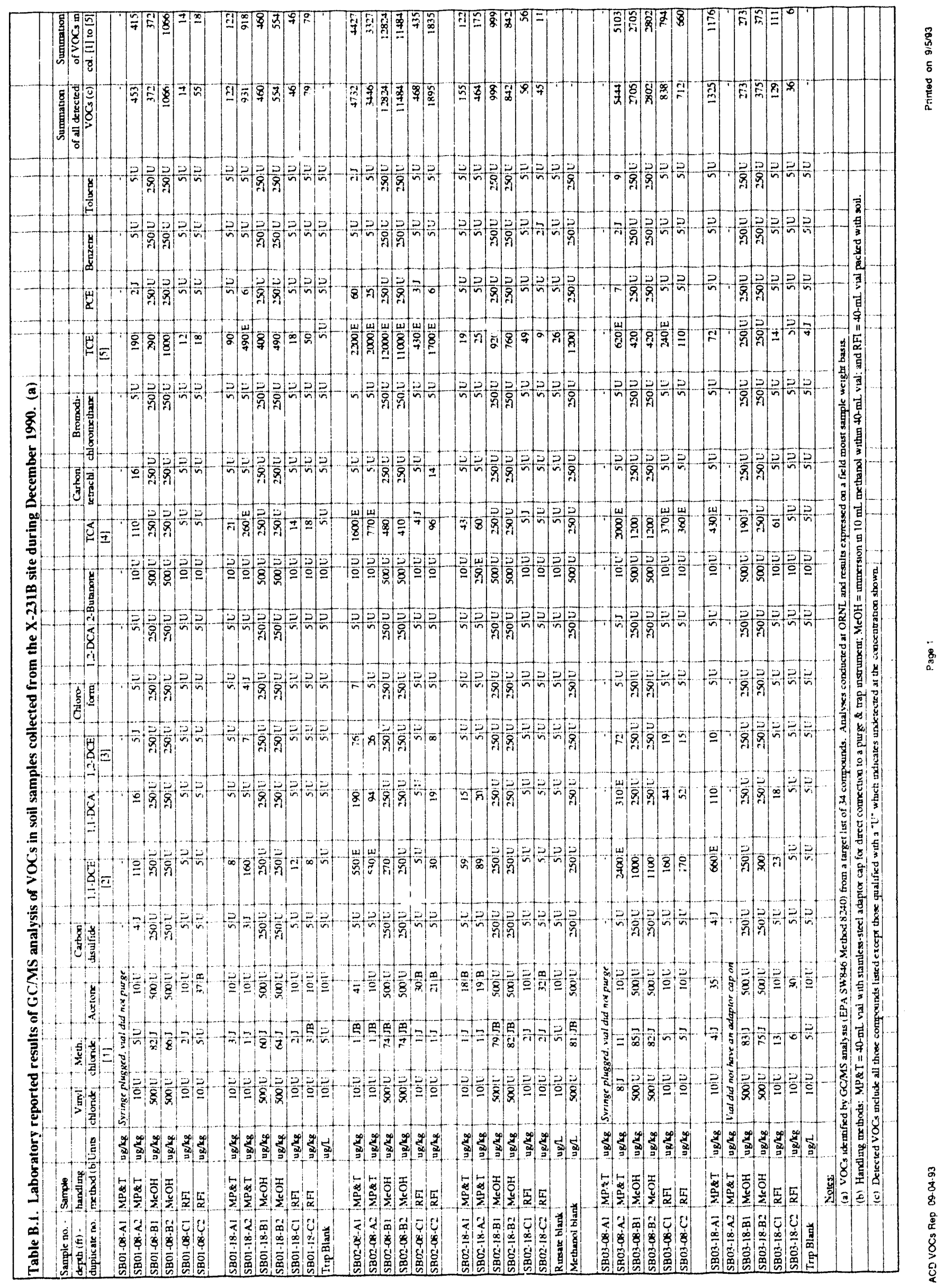




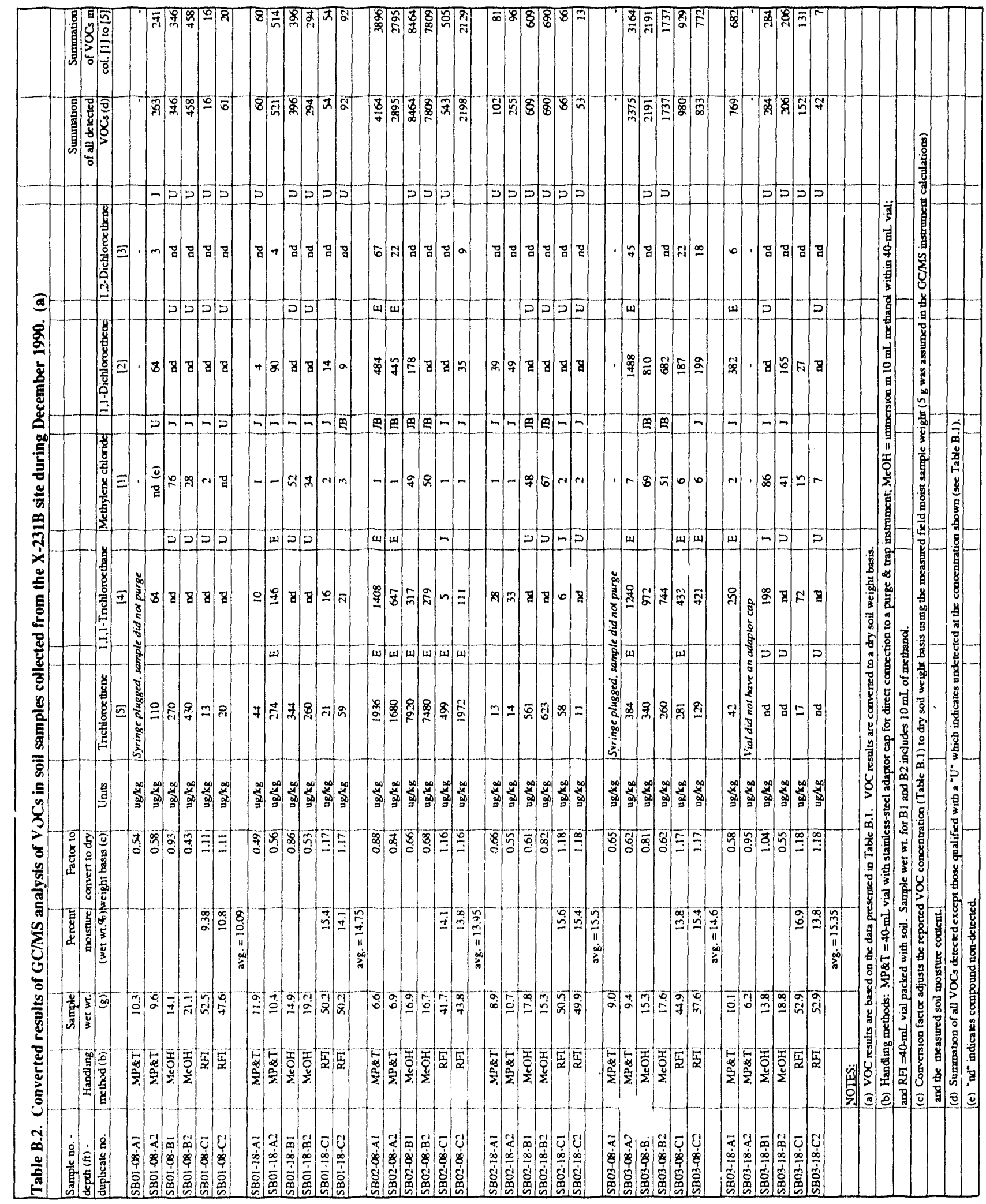


APPENDIX C. TECHNOLOGY VENDOR REQUEST FOR INFORMATION 


\section{PROJECT FACT SHEET \\ Remediation Technologies for Contaminated Soils}

\section{BACKGROUND}

Demonstration projects for innovative remediation technologies (on-site or in situ) for environmental restoration of contaminated problem soils are being undertaken by Oak Ridge National Laboratory (ORNL) with funding provided by the U.S. Department of Energy through Martin Marietta Energy Systems, Inc.. One aspect of this work involves sites within the U.S. DOE system which have subsurface contamination problems in difficult soil/geologic materials. These may be characterized generically as wet to saturated, fine textured, low permeable soil/geologic materials contaminated with variable mixtures of organic and inorganic chemicals and in some cases radionuclides. Soil treatment is necessary to reduce soil associated contaminant levels and thereby reduce direct exposure risks as well as reduce/eliminate the soil as a source of groundwater contamination.

\section{SITE CHARACTERISTICS}

The type of problem site under consideration is illustrated by the site characteristics given below.

The Site is located in the midwestern United States and was used for approximately 10 years during the 1970's and 1980's for land application of waste oils and degreasing solvents. Some of the wastes contained uranium-235 and technetium-99. The precise character of waste materials deposited is unknown. The Site encompasses approximately 1 acre or less. Underground utilities may pass through the fringes of the contaminated soil areas. As a result of the waste disposal activities, subsurface contamination is present in the soil and groundwater beneath and adjacent to the Site.

The Site consists of approximately $30 \mathrm{ft}$ of unconsolidated material. The upper 10 to $25 \mathrm{ft}$ is comprised of a low permeability clays and silts (permeability ranging from $1 \times 10^{-2}$ to $1 \times 10^{-4}$ $\mathrm{ft} / \mathrm{day})$. Below the silts and clays is a more permeable basal unit ( $\mathrm{K}=1$ to $10 \mathrm{ft} / \mathrm{day}$ ) with a thickness of 5 to $10 \mathrm{ft}$ The depth to the groundwater table is approximately $10 \mathrm{ft}$

Soil contamination is confined to the unconsolidated units. Contamination consists primarily of solvents such as trichloroethene (TCE), 1,1,1-trichloroethane (TCA), acetone and freon-113 (Table 1). Concentrations of volatile organic compounds (VOCs) are typically in the ug/g range and are distributed throughout the soil profile from ground surface to the underlying consolidated units (i.e., 0 to $30 \mathrm{ft}$ depth). Relatively higher VOC concentrations appear near the water table surface (i.e., approximately $10 \mathrm{ft}$ depth).

Herbicides and PCBs have not been detected. Contamination with metals is either minor or not present. Radioactive contamination is present but at low levels. Typically, total alpha and beta ranges do not exceed $100 \mathrm{nCi} / \mathrm{kg}$ near the surface and decrease to $<10 \mathrm{nCi} / \mathrm{kg}$ at depths approaching $30 \mathrm{ft}$.

Analyses of water from Site monitoring wells show that the primary contaminants are TCE and TCA. The concentration of total VOCs range to approximately $5 \mathrm{mg} / \mathrm{L}$ which is comprised of approximately $50 \% \mathrm{TCE}$ and lesser amounts of 1,1-dichloroethene, 1,2-dichloroethene, chloroform, and 1,1,1-trichloroethane. Traces $(<1() \mathrm{ug} / \mathrm{L})$ of methylene chloride, freon, benzene, and ethylbenzene are often reported as well. The concentrations of naturally occurring metals are low except for iron which ranges to more than $20 \mathrm{mg} / \mathrm{L}$. 


\section{REQUESTED INFORMATION}

At this time we are soliciting input from vendors of innovative technologies for treatment of the contaminated soil at sites such as described below. Effective treatment of the soils will result in reduction (removal or degradation) or immobilization of volatile organic compounds (VOCs) defined as:

1. Remove or destroy VOCs so residual soil concentration is less than $1 \mathrm{mg} / \mathrm{kg}$; or

2. Immobilize VOCs so concentrations in leachate from TCLP tests are below U.S. EPA hazardous waste criteria levels.

If your company has one or more technologies that would be applicable to sites such as described herein, please complete and return the enclosed survey form by January 15, 1991.

The attached Vendor/Technology survey form requests information regarding innovative technologies for remediation of sites such as the one described above. As part of this request, an estimated cost for both a site demonstration and a full scale remediation is needed. These costs should be based on the following information:

1. Pretesting (treatability) as needed and Mobilization (delivery and setup), Treatment, and Demobilization (decontamination and removal) of equipment.

2. All permitting to be completed by Martin Marietta Energy Systems, Inc. (MMES).

3. Support MMES permitting activities and site requirements.

4. Demonstration plot size: Approximately 1,000 square feet by 30 feet deep.

5. Full scale remediation plot size: Approximately 100,000 square feet by 30 feet deep.

Should you have any questions concerning completion of the survey form, please contact Mike Morris at 615-574-0559 (Telefax 615-576-0327) or Bob Siegrist at 615-574-7286 (Telefax 615576-8646). Thank you for your participation in this technology evaluation. We look forward to receiving your completed survey form by January 15, 1991.

Sincerely,

Michael I. Morris

Project Demo Coordinator

Chemical Technology Division MS 37831-7306 Tel.615-574-0559 Fax 615-576-0327

Robert L. Siegrist, Ph.D., P.E.

Principal Investigator

Environmental Sciences Division MS 37831-6038 Tel. 615-574-7286 Fax 615-576-8646 
DATE:

COMPANY:

CONTACT:

ADDRESS:

POSITION:

CITY, STATE, ZIP:

TELEPHONE:

PROCESS TECHNOLOGY FOR SOIL OR WATER:

PROCESS NAME:

DESCRIPTION:

SOILS TREATMENT REMOVAL OR IMMOBILIZATION:

SOILS TREATMENT IN SITU OR EX SITU:

PROCESS CAN MEET TREATMENT GOALS (Describe):

STAGE OF DEVELOPMENT:

APPROXIMATE NUMBER OF SUCCESSFUL REMEDIATIONS:

SECONDARY WASTE STREAMS PRODUCED:

CHEMICAL REQUIREMENTS:

PERMITS REQUIRED (Name):

POTENTIAL SAFETY RISKS:

POTENTIAL ENVIRONMENTAL RISKS: 
DEMONSTRATION:

EQUIPMENT READILY AVAILABLE:

TIME FOR INSTALLATION AND OPERATION:

PROCESSING RATES:

UTILITY REQUIREMENTS:

ESTIMATED COST:

FULL SCALE REMEDIATION:

EQUIPMENT READILY AVAILABLE:

TIME FOR INSTALLATION AND OPERATION:

PROCESSING RATES:

UTILITY REQUIREMENTS:

ESTIMATED COST:

UNUSUAL REQUIREMENTS:

OTHER:

RETURN FORM TO:

MR. MICHAEL MORRIS

MARTIN MARIETTA ENERGY SYSTEMS

K-25 SITE

BLDG. K-1101

OAK RIDGE, TN 37831-7306

COMPLETED FORM REQUEST RETURN DATE: JANUARY 15, 1991 
APPENDIX D. TECHNOLOGY ASSESSMENT SCREENING INFORMATION 


$$
\text { (n) }
$$

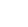




\section{X231-B UNIT SOILS DEMONSTRATION TECHNOLOGY ASSESSMENT SCREENING DATA SHEET}

1. TECHNOLOGY TYPE: Solicification/stabilization.

2. PROCESS LESCRIPTION: The process entails mixing the soil with a $10 \mathrm{ft}$ auger, and simultaneously adding additive for stabilization and solidification.

3. IN SITU or EX SITU: In situ.

4. POTENTIAL VENDORS, CONTACT, PHONE, ADDRESS: Hayward Baker, 1875 Mayfield Road, Erdenton. Maryland 21113. Joe Welch or George Grieshem.

5. REMOVAL or IMMOBILIZATION OF VOC: Immobilize.

6. TREATED WASTE CHARACTERIZATION; PROCESS CAN REMOVE VOC TO $1 \mathrm{mg} / \mathrm{kg}$ or IMMOBILIZE TO TCLP: Yes.

7. STAGE OF DEVELOPMENT: Has been done on waste site.

8. TIME FOR INSTALLATION \& OPERATION: approx. 1 month.

9. PROCESSING RATES: Approx. $10,000 \mathrm{ft}^{3} / \mathrm{d}$.

10. PROCESS EQUIPMENT READILY AVAILABLE: Yes.

11. APPROXIMATE NO. SUCCESSFUL REMEDIATIONS: Did not answer.

12. SECONDARY WASTE STREAMS PRODUCED: None.

13. UTILITY REQUIREMENTS: Water (however, primarily self sufficient).

14. CHEMICALS: Proprietary.

15. POTENTIAL ENVIRONMENTAL IMPACT RISKS: None.

16. POTENTIAL SAFETY RISKS: Minimal exposure.

17. OTHER:

Name: $\quad$ M. T. Harris

Date: $\quad 01 / 07 / 91$ 


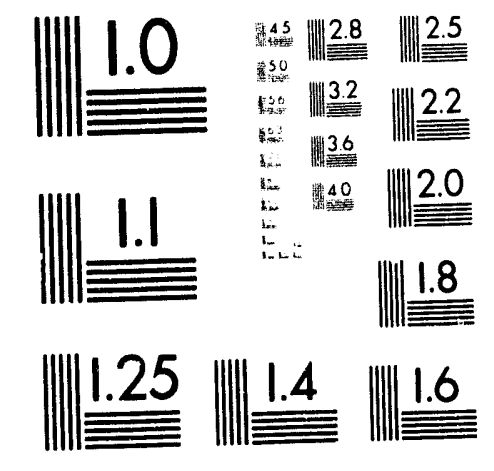



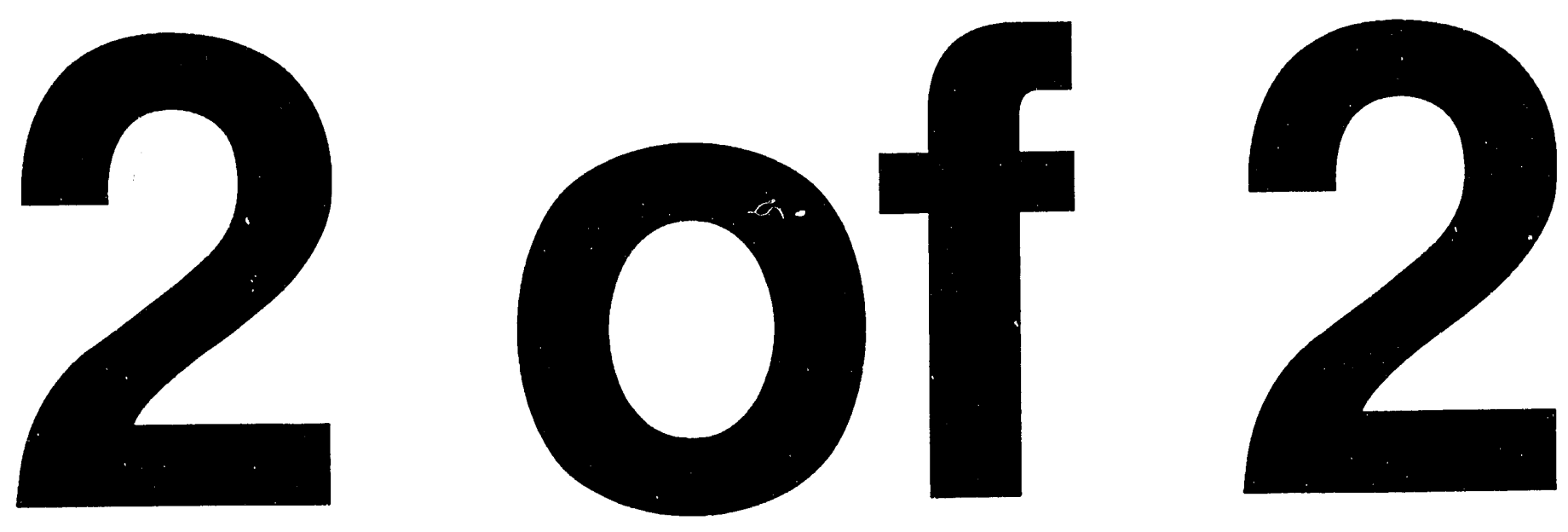


\section{X231-B UNIT SOILS DEMONSTRATION \\ TECHNOLOGY ASSESSMENT SCREENING DATA SHEET}

1. TECHNOLOGY TYPE: Triple system jet grouting.

2. PROCESS DESCRIPTION: This system consists of a triple annulus where water, air, and grout are injected at high pressures. First water and air are injected to excavate the soil by bringing the returns to the surface which is enclosed to prevent escape of VOC to atmosphere. The soil is treated by a suitable technique, mixed with grout, and returned to excavated area to soil.

3. IN SITU or EX SITU: In situ

4. POTENTIAL VENDORS, CONTACT, PHONE, ADDRESS: Hayward Baker, Inc., 1875 Mayfield Road, Erdenton, Maryland 21113. Alan R. Ringen (301) 551-8200.

5. REMOVAL or IMMOBILIZATION OF VOC: Removal and/or immobilization.

6. TREATED WASTE CHARACTERIZATION; PROCESS CAN REMOVE VOC TO $1 \mathrm{mg} / \mathrm{kg}$ or IMMOBILIZE TO TCLP: probably Yes.

7. STAGE OF DEVELOPMENT: Engineering tool has been developed; treatment of VOC needs additional work.

8. TIME FOR INSTALLATION \& OPERATION: approx. 2 months.

9. PROCESSING RATES: Approx. $200 \mathrm{yd}^{3} / \mathrm{d}$.

10. PRDCESS EQUIPMENT READILY AVAILABLE: Yes.

11. APPROXIMATE NO. SUCCESSFUL REMEDIATIONS: 1 - phenol removal from soil.

12. SECONDARY WASTE STREAMS PRODUCED: Large returns.

13. UTILITY REQUIREMENTS: Electricity and water.

14. CHEMICALS: Generally (none). Would be possible to use chemical oxidizing agent.

15. POTENTIAL ENVIRONMENTAL IMPACT RISKS: Minimal.

16. POTENT!AL SAFETY RISKS: High pressure (approx. 6,000 psi).

17. OTHER:

Name:

M. T. Harris

Date:

(01/18/91 


\section{X231-B UNIT SOILS DEMONSTRATION \\ TECHNOLOGY ASSESSMENT SCREENING DATA SHEET}

1. TECHNOLOGY TYPE: In situ hot-air/steam stripping.

2. PROCESS DESCRIPTION: Steam and/or hot air is injected into the subsurface and desorbs and volatilizes VOCs and to some extent SVOCs. Injection can be through a hollow drilling rig while drilling proceeds (Toxics Treatments "Detoxifier" and Geo-Con's "Deep Soil Mixing" system) or into an injection/extraction well system (Solvent Service's Steam Injection and Vacuum Extraction system (SIVE) and the Heijamans Milieutechniek B.V. system). Solidification agents or oxidizing chemicals may also be injected simultaneously.

3. IN SITU or EX SITU: In situ.

4. POTENTIAL VENDORS, CONTACT, PHONE, ADDRESS: Toxic Treatments (USA) Inc., Phil La Mori, 415-391-2113, 151 Union St., Suite 155, San Francisco, CA 94111. Geo-Con, Inc., Brian Jasperse, 412-8567700, P.O. Box 17380, Pittsburgh, PA 15235. Solvent Service, Inc., Doug Dieter, 408-453-6046, 1040 Commercial Street, Suite 101, San Jose, CA 95112. Heijmans Milieutechniek B.V., Mr. C. Jonker, 04192-89111, P.O. Box 2, 5240 BB Rosmalen, Netherlands.

5. REMOVAL or IMMOBILIZATION OF VOC: Removal and potential for immobilization via injection of immobilizing agent.

6. TREATED WASTE CHARACTERIZATION; PROCESS CAN REMOVE VOC TO $1 \mathrm{mg} / \mathrm{kg}$ or IMMOBILIZE TO TCLP: EPA Site program data showed an average removal of VOCs from an initial value of $475 \mathrm{ppm}$ to $71 \mathrm{ppm}$. Longer treatment times should produce more effective treatment.

7. STAGE OF DEVELOPMENT: Field tested at a San Pedro, CA, site through the EPA Site program and also tested at same site under supervision of state of CA.

8. TIME FOR INSTALLATION \& OPERATION: Rapid start-up.

9. PROCESSING RATES: Depending on type and depth of contaminant and soil about 3 to $10 \mathrm{yd}^{3} / \mathrm{h}$.

10. PROCESS EQUIPMENT READILY AVAILABLE: May be availability problems due to previous commitments.

11. APPROXIMATE NO. SUCCESSFUL REMEDIATIONS: Two tests in Site program and one under state of CA supervision considered successful. All three tests performed at same site. Also tested with success at another CA site contaminated with petroleum hydrocarbons.

12. SECONDARY WASTE STREAMS PRODUCED: Contaminants in off-gas and condensate. 
In situ steam/hot air stripping continued ...

13. UTILITY REQUIREMENTS: Steam supply for drilling and steam/hot air; electrical for monitoring and process control equipment.

14. CHEMICALS: Drilling fluids and possibly solidification agents and oxidizing chemicals.

15. POTENTIAL ENVIRONMENTAL IMPACT RISKS: VOCs and particulates in off-gas. Both removed in off-gas treatment system. Disposal or recovery of contaminants from conder a ate.

16. POTENTIAL SAFETY RISKS: VOC exposure and hazards associated with drilling operations.

17. OTHER: Cost estimated at $\$ 317 / \mathrm{yd}^{3}$ treated at $3 \mathrm{yd}^{3} / \mathrm{hr}$. Can be used in unsaturated and saturated zones to a total depth of $30 \mathrm{ft}$ with present equipment. Underground obstructions may interfere.

Name:

C. M. Morrissey

Date:

01/16/91 


\section{X231-B UNIT SOILS DEMONSTRATION \\ TECHNOLOGY ASSESSMENT SCREENING DATA SHEET}

1. TECHNOLOGY TYPE: In situ jet mixing.

2. PROCESS DESCRIPTION: Jet mixing is the use of high pressure $(4,000$ to $6,000 \mathrm{psi})$ liquid jets to mix soil with a grout or chemicals. The grout slurry exiting the jets at high velocity impinges on the soil and shatters it for some distance from the jets. At the same time, the grout slurry is uniformly and intimately mixed with soil particles.

3. IN SITU or EX SITU: In situ

4. POTENTIAL VENDORS, CONTACT, PHONE, ADDRESS: Halliburton Environmental Technology, P.O. Box 721110 Houston, Texas 77272 . Jack Mote (12/24/90) and Jerry Mote $(1 / 17 / 91)(713) 561-1556$.

5. REMOVAL or IMMOBILIZATION OF VOC: Removal and/or immobilization.

6. TREATED WASTE CHARACTERIZATION; PROCESS CAN REMOVE VOC TO $1 \mathrm{mg} / \mathrm{kg}$ or IMMOBILIZE TO TCLP: N/A.

7. STAGE OF DEVELOPMENT: Never done to remove VOC.

8. TIME FOR INSTALLATION \& OPERATION: Approx. 1 month.

9. PROCESSING RATES: N/A.

10. PROCESS EQUIPMENT READILY AVAILABLE: N/A.

11. APPROXIMATE NO. SUCCESSFUL REMEDIATIONS: None.

12. SECONDARY WASTE STREAMS PRODUCED: Large solution returns to surface.

13. UTILITY REQUIREMENTS: Self contained.

14. CHEMICALS: N/A.

15. POTENTIAL ENVIRONMENTAL IMPACT RISKS:

16. POTENTIAL SAFETY RISKS: Extremely high pressure (approx. 4,000 - 6,000 psi).

17. OTHER: This process is not recommended for VOC removal.

Name:

M. T. Harris

Date:

$12 / 24 / 90$ 


\section{X231-B UNIT SOILS DEMONSTRATION \\ TECHNOLOGY ASSESSMENT SCREENING DATA SHEET}

1. TECHNOLOGY TYPE: In situ RF or EM Heating.

2. PROCESS DESCRIPTION: The process removes the hazardous contaminants by ex situ heating of the contaminated soil. The process uses radio fi equency or electromagnetic energy to heat the soil without the introduction of heatirg liquids or steam. RF heating is used when higher temperatures are required (up to $200^{\circ} \mathrm{C}$ ) or EM heating when lower temperatures (to $100^{\circ} \mathrm{C}$ ) are acceptable. This application would use EM heating.

3. IN SITU or EX SITU: In situ.

4. POTENTIAL VENDORS, CONTACT, PHONE, ADDRESS: IIT Research Institute, 10 W. 35th street, Chicago, IL., 312-567-4363, Gug Sresty. Only one vendor.

5. REMOVAL or IMMOBILIZATION OF VOC: Removal.

6. TREATED WASTE CHARACTERIZATION; PROCESS CAN REMOVE VOC TO $1 \mathrm{mg} / \mathrm{kg}$ or IMMOBILIZE TO TCLP: Ye:

7. STAGE OF DEVELOPMENT: Pilot scale demonstration only. No site remediations. Pilot scale demonstration only. No site remediations.

8. TIME FOR INSTALLATION \& OPERATION: Approximately 5 months; 3 for installation and 2 for operation.

9. PROCESSING RATES: Approximately 25 tons/d or $20 \mathrm{yd}^{3} / \mathrm{d}$ for demo; full scale 200 tons/d.

10. PROCESS EQUIPMENT READILY AVAILABLE: According to vendor, "Detailed designs available. Equipment can be readily acquired."

11. APPROXIMATE NO. SUCCESSFUL REMEDIATIONS: None.

12. SECONDARY WASTE STREAMS PRODUCED: Three steams, vapor treated by carbon, groundwater which needs to be diverted and then treated by IX, and off-gas treated by carbon. Eventual waste for final disposal would be carbon and IX resin.

13. UTILITY REQUIREMENTS: 300KVA of $60 \mathrm{~Hz}$ for demo and 2100KVA for full scale.

14. CHEMICALS: None.

15. POTENTIAL ENVIRONMENTAL IMPACT RISKS: "None".

16. POTENTIAL SAFETY RISKS: AC shock, exposure to RF radiation, and risk of formation of explosive gas. All can be handled by prudent equipment design and operation. 
In situ RF or EM Heating continued ...

17. OTHER: The process does meet the MUSTs for the KT analysis and therefore can be considered. However, I think the process is still not tested enough to take a chance on it for the demo. Secondly, the processing rates for full scale application would take approximately $2+$ years, much to long. Thirdly, the costs for the demo just for the vendor is $\$ 1.35$ million which I feel is way too expensive. Finally, only one vendor can supply the equipment making it more difficult to give a contract with this amount of dollars involved. This should all fall out during the $\mathrm{KT}$ procedure.

$\begin{array}{ll}\text { Name: } & \text { M. I. Morris } \\ \text { Date: } & 01 / 17 / 91\end{array}$




\section{X231-B UNIT SOILS DEMONSTRATION \\ TECHNOLOGY ASSESSMENT SCREENING DATA SHEET}

1. TECHNOLOGY TYPE: Peroxide treatment.

2. PROCESS DESCRIPTION: This process is known as the chemical oxidation treatment process It involves excavating the soil, loading soil on a hopper under vacuum and adding peroxide to oxidize the organics. Other chemicals are used to enhance oxidation. The treated soil is returned to the excavated area.

3. IN SITU or EX SITU: Ex situ.

4. POTENTIAL VENDORS, CONTACT, PHONE, ADDRESS: ENSO TECH, Inc., 7949 Ajay Dr., Sunny Valley, California 91352. Khalique Khan (818) 767-2222; Environmenial and Geotechnical Services, 6701 Cherry Ave., Long Beach, California 90805, (213) 4280288 .

5. REMOVAL or IMMOBILIZATION OF VOC: Removal.

6. TREATED WASTE CHARACTERIZATION; PROCESS CAN REMOVE VOC TO $1 \mathrm{mg} / \mathrm{kg}$ or IMMOBILIZE TO TCLP: Less than $1 \mathrm{mg} / \mathrm{kg}$.

7. STAGE OF DEVELOPMENT: Has been used on VOC sites.

8. TIME FOR INSTALLATION \& OPERATION: Installation approx. a w'eek; operation approx. a month.

9. PROCESSING RATES: Approx. $100 \mathrm{yd} \cdot 3 / \mathrm{d}$.

10. PROCESS EQUIPMENT READILY AVAILABLE: Yes.

11. APPROXIMATE NO. SUCCESSFUL REMEDIATIONS: Approx. 100 sites containing TCE or PCE.

12. SECONDARY WASTE STREAMS PRODUCED: Air.

13. UTILITY REQUIREMENTS: Self contained unit.

14. CHEMICALS: Hydrogen peroxide.

15. POTENTIAL ENVIRONMENTAL IMPACT RISKS: Minimal.

16. POTENTIAL SAFETY RISKS: Minimal.

17. OTHER:

$\begin{array}{ll}\text { Name: } & \text { M. T. Harris } \\ \text { Date: } & 01 / 07 / 91\end{array}$




\section{X231-B UNIT SOILS DEMONSTRATION \\ TECHNOLOGY ASSESSMENT SCREENING DATA SHEET}

1. TECHNOLOGY TYPE: Ex situ thermal desorption

2. PROCESS DESCRIPTION: The process removes the hazardous contaminants by in situ heating of the contaminated soil. The process typically uses a rotary dryer with an inert carrier gas and off gas treatment system to heat the soil to remove the VOCs. Depending on the temperature it can also drive of most Semivolatiles. The contaminated soil must be dug up and then taken to the equipment.

3. IN SITU or EX SITU: Ex situ.

4. POTENTIAL VENDORS, CONTACT, PHONE, ADDRESS: Several vendors, including: IT Corp., Chem Nuclear, Westinghouse, Geo Con, Weston, etc.

5. REMOVAL or IMMOBILIZATION OF VOC: Removal.

6. TREATED WASTE CHARACTERIZATION; PROCESS CAN REMOVE VOC TO $1 \mathrm{mg} / \mathrm{kg}$ or IMMOBILIZE TO TCLP: Yes.

7. STAGE OF DEVELOPMENT: Field scale to bench scale depending on vendor.

8. TIME FOR INSTALLATION \& OPERATION: Depending on which vendor you talk to (two vendors Weston and Separations \& Recovery Systems [SRS] have large systems) it can be done with in the 5 months. However some of the vendors only have pilot scale equipment and could not possibly do the demo on as large a scale as we have defined it or it would take them as much as 2 years to process it.

9. PROCESSING RATES: Full-scale is 100-200 tons/day.

10. PROCESS EQUIPMENT READILY AVAILABLE: Again depending on the vendor it may or may not be readily available.

11. APPROXIMATE NO. SUCCESSFUL REMEDIATIONS: "on going 15 to date" by SRS Inc. Weston has 2.

12. SECONDARY WASTE STREAMS PRODUCED: Condensate after vapor off gas condensation.

13. UTILITY REQUIREMENTS: $460 \mathrm{~V}, 1000$ amps electric; also maybe steam.

14. CHEMICALS: None.

15. POTENTIAL ENVIRONMENTAL IMPACT RISKS: "None".

16. POTENTIAL. SAFETY RISKS: "None". 
Ex situ thermal desorption continued ...

17. OTHER: The process does meet the MUSTs for the KT analysis and therefore can be considered. However, I think the process equipment from most vendors is still not tested on a large scale that could meet our current demo requirement in the time frame proposed of 5 months. I would have to investigate SRS claim of 15 remediations. Weston appears to be viable. Also the cost for the demo is very expensive $\$ 500-600 \mathrm{~K}$ (small scale) or up to $\$ 5$ million for full scale demo just for the vendor. Full scale site as much as $\$ 25$ million taking 3-4 years. This is the information from the vendors that I was able to contact. This should all fall out during the KT procedure.

Name:

M. I. Morris

Date:

$01 / 21 / 91$ 


\section{X231-B UNIT SOILS DEMONSTRATION \\ TECHNOLOGY ASSESSMENT SCREENING DATA SHEET}

1. TECHNOLOGY TYPE: Solidification/stabilization.

2. PROCESS DESCRIPTION: The soil is removed in the mixing equipment where a proprietary chemical is added. The VOCs are altered and immobilized. A monolith is formed.

3. IN SITU or EX SITU: Ex situ.

4. POTENTIAL VENDORS, CONTACT, PHONE, ADDRESS: Wastech Inc. (specialists in organics), P.O. Box 1213, Oak Ridge, Tennessee 37831-1213. Mike Brown, (615) 4836515 .

5. REMOVAL or IMMOBILIZATION OF VOC: Alters VOC \& immobilizes.

6. TREATED WASTE CHARACTERIZATION; PROCESS CAN REMOVE VOC TO $1 \mathrm{mg} / \mathrm{kg}$ or IMMOBILIZE TO TCLP: Yes.

7. STAGE OF DEVELOPMENT: Done primarily as demos and treatability studies.

8. TIME FOR INSTALLATION \& OPERATION: Approx. 1 month.

9. PROCESSING RATES: $10,000-20,000 \mathrm{ft}^{3} / \mathrm{d}$.

10. PROCESS EQUIPMENT READILY AVAILABLE: Yes.

11. APPROXIMATE NO. SUCCESSFUL REMEDIATIONS: None (just treatability studies).

12. SECONDARY WASTE STREAMS PRODUCED: None.

13. UTILITY REQUIREMENTS: Electricity.

14. CHEMICALS: Proprietary.

15. POTENTIAL ENVIRONMENTAL IMPACT RISKS: None.

16. POTENTIAL SAFETY RISKS: Those associated with general contractor excavation.

17. OTHER:

Name: $\quad$ M. T. Harris

Date: $\quad 01 / 04 / 91$ 
APPENDIX E. RESULTS OF TECHNOLOGY RANKING PROCESS 
Table E.1. X-231B Plot soil remediation demonstration Kepner-Tregoe analysis wants weighting summary.

\begin{tabular}{|c|c|c|c|c|c|c|c|}
\hline \multirow[b]{2}{*}{ Evaluator } & \multicolumn{7}{|c|}{ Weighting by technology want $\underline{\mathrm{a}}$} \\
\hline & 1 & 2 & 3 & 4 & 5 & 6 & 7 \\
\hline 1 & 8 & 8 & 6 & 5 & 10 & 2 & 3 \\
\hline 2 & 10 & 8 & 5 & 3 & 7 & 5 & 2 \\
\hline 3 & 7 & 9 & 5 & 10 & 3 & 6 & 8 \\
\hline 4 & 10 & 4 & 7 & 7 & 4 & 4 & 4 \\
\hline 5 & 10 & 8 & 9 & 6 & 2 & 3 & 4 \\
\hline 6 & 5 & 4 & 8 & 2 & 10 & 7 & 6 \\
\hline 7 & 9 & 8 & 10 & 10 & 8 & 7 & 6 \\
\hline 8 & 8 & 1 & 10 & 7 & 2 & 4 & 6 \\
\hline 9 & 10 & 7 & 9 & 5 & 3 & 5 & 5 \\
\hline 10 & 8 & 5 & 5 & 10 & 5 & 2 & 7 \\
\hline 11 & 10 & 7 & 3 & 7 & 8 & 5 & 5 \\
\hline 12 & 10 & 5 & 5 & 5 & 10 & 5 & 7 \\
\hline 13 & 8 & 7 & 10 & 4 & 3 & 2 & 5 \\
\hline 14 & 8 & 8 & 10 & 5 & 8 & 3 & 10 \\
\hline Total & 121 & 95 & 102 & 86 & 83 & 60 & 78 \\
\hline $\begin{array}{l}\text { Average } \\
\text { weight }\end{array}$ & 8.6 & 6.8 & 7.3 & 6.1 & 5.9 & 4.3 & 5.6 \\
\hline Rank & 1 & 3 & 2 & 4 & 5 & 7 & 6 \\
\hline $\begin{array}{l}\text { Average with } \\
\text { high and low } \\
\text { value omitted }\end{array}$ & 8.8 & 6.8 & 7.4 & 6.1 & 5.9 & 4.3 & 5.5 \\
\hline
\end{tabular}

a Technology "wants":

1. Assurance of process reliability, operability, and maintainability.

2. Minimize secondary waste.

3. Minimize costs.

4. Minimize occupational exposure and risk to public during demonstration.

5. Remove or destroy VOCs versus immobilization.

6. Ability to handle non-VOC hazardous components.

7. Applicability of process to other DOE sites. 
Table E.2. Summary of X-231B demonstration Kepner - Tregoe analysis.

\begin{tabular}{|c|c|c|c|c|c|c|c|c|c|c|c|c|}
\hline \multirow[b]{2}{*}{ Technology } & \multicolumn{3}{|c|}{ Musts a } & \multicolumn{7}{|c|}{ Wants $\mathrm{b}$} & \multirow[b]{2}{*}{$\begin{array}{l}\text { Total } \\
\text { score } \underline{\mathrm{c}}\end{array}$} & \multirow{2}{*}{$\begin{array}{l}\text { Total } \\
\text { score } \\
\text { without } \\
\text { cost } \underline{\mathrm{c}}\end{array}$} \\
\hline & 1 & 2 & 3 & 1 & 2 & 3 & 4 & 5 & 6 & 7 & & \\
\hline \multicolumn{13}{|l|}{ In situ immobilization } \\
\hline Score & Y & Y & $\mathrm{Y}$ & 8.3 & 9.2 & 7.4 & 8.8 & 0.4 & 9.2 & 8.5 & & \\
\hline Weight factor & & & & 8.6 & 6.8 & 7.3 & 6.1 & 5.9 & 4.3 & 5.6 & & \\
\hline Weighted score (rank) & & & & 71.4 & 62.6 & 54.0 & 53.7 & 2.4 & 39.6 & 47.6 & $331(1)$ & $277(1)$ \\
\hline \multicolumn{13}{|l|}{ In situ air/steam stripping } \\
\hline Score & $\mathrm{Y}$ & $Y$ & $\mathrm{Y}$ & 6.6 & 6.7 & 6.9 & 7.5 & 9.5 & 2.8 & 7.5 & & \\
\hline Weight factor & & & & 8.6 & 6.8 & 7.3 & 6.1 & 5.9 & 4.3 & 5.6 & & \\
\hline Weighted score (rank) & & & & 56.8 & 45.6 & 50.4 & 45.8 & 56.1 & 12.0 & 42.0 & $308(3)$ & $258(4)$ \\
\hline \multicolumn{13}{|l|}{ In situ electrokinetics } \\
\hline Score & $\mathrm{N}$ & $Y ?$ & $Y$ & 3.6 & 6.3 & 5.2 & 7.3 & 3.2 & 7.3 & 4.1 & & \\
\hline Weight factor & & & & 8.6 & 6.8 & 7.3 & 6.1 & 5.9 & 4.3 & 5.6 & & \\
\hline Weighted score (rank) & & & & 31.0 & 42.8 & 38.0 & 44.5 & 18.9 & 31.4 & 23.0 & $230(8)$ & $192(8)$ \\
\hline \multicolumn{13}{|l|}{ In situ slurry reactor } \\
\hline Score & $Y ?$ & $\mathrm{Y}$ & $Y$ & 4.7 & 6.0 & 6.3 & 6.8 & 2.1 & 7.5 & 5.8 & & \\
\hline Weight factor & & & & 8.6 & 6.8 & 7.3 & 6.1 & 5.9 & 4.3 & 5.6 & & \\
\hline Weighted score (rank) & & & & 40.4 & 40.8 & 46.0 & 41.5 & 12.4 & 32.3 & 32.5 & $246(i)$ & $200(7)$ \\
\hline \multicolumn{13}{|l|}{ In situ RF/EM heating } \\
\hline Score & Y & Y & $\mathrm{Y}$ & 4.4 & 6.1 & 5.3 & 6.1 & 9.3 & 2.0 & 5.8 & & \\
\hline Weight factor & & & & 8.6 & 6.8 & 7.3 & 6.1 & 5.9 & 4.3 & 5.6 & & \\
\hline Weighted score (rank) & & & & 37.8 & 41.5 & 38.7 & 37.2 & 54.9 & 8.6 & 32.5 & $251(6)$ & $213(6)$ \\
\hline \multicolumn{13}{|l|}{ In situ (ex situ) peroxide } \\
\hline Score & Y & $\mathrm{Y}$ & $\mathrm{Y}$ & 8.1 & 7.0 & 5.3 & 5.9 & 8.6 & 3.4 & 7.0 & & \\
\hline Weight factor & & & & 8.6 & 6.8 & 7.3 & 6.1 & 5.9 & 4.3 & 5.6 & & \\
\hline Weighted score (rank) & & & & 69.7 & 47.6 & 38.7 & 36.0 & 50.7 & 14.6 & 39.2 & $296(5)$ & $258(5)$ \\
\hline \multicolumn{13}{|l|}{ Ex situ thermal treatment } \\
\hline Score & Y & Y & $Y$ & 8.2 & 7.2 & 4.7 & 5.6 & 10.0 & 3.2 & 7.5 & & \\
\hline Weight factor & & & & 8.6 & 6.8 & 7.3 & 6.1 & 5.9 & 4.3 & 5.6 & & \\
\hline Weighted score (rank) & & & & 70.5 & 49.0 & 34.3 & 34.2 & 59.0 & 13.8 & 42.0 & $303(4)$ & $268(2)$ \\
\hline \multicolumn{13}{|l|}{ Ex situ immobilization } \\
\hline Score & Y & Y & $Y$ & 9.2 & 7.9 & 6.7 & 6.3 & 0.8 & 9.8 & 8.3 & & \\
\hline Weight factor & & & & 8.6 & 6.8 & 7.3 & 6.1 & 5.9 & 4.3 & 5.6 & & \\
\hline Weighted score (rank) & & & & 79.1 & 53.7 & 48.9 & 38.4 & 4.7 & 42.1 & 46.5 & $314(2)$ & $265(3)$ \\
\hline
\end{tabular}

a Technology "musts":

1. Meet VOC treatment goals; 2. Complete demonstration within 5 months; and 3. Meet all permits, safety, \& QA.

b Technology "wants":

1. Assurance of process $\mathrm{R} / \mathrm{O} / \mathrm{M} ; 2$. Minimize secondary waste; 3 . Minimize costs;

4. Minimize occupational exposure and risk to public during demonstration:

5. Remove or destroy VOCs versus immobilize; 6 . Ability to handle non-VUC hazardous components; and 7. Applicability of process to other DOE sites.

$c$ Total score is weighted according to total rating per want and the weight assigned to that want.

Overall rank $(1=$ highest $)$ is given in parenthesis. 
Table E.3. Summary of Kepner-Tregoe results for in situ immobilization.

\begin{tabular}{|c|c|c|c|c|c|c|c|c|c|c|c|c|}
\hline \multirow[b]{2}{*}{ Evaluator } & \multicolumn{4}{|c|}{ "Musts" a } & \multicolumn{4}{|c|}{ "Wants" b } & & & \multirow{2}{*}{\multicolumn{2}{|c|}{$\begin{array}{ll} & \text { Total } \\
& \text { score } \\
\text { Total } & \text { w/o } \\
\text { score } \mathrm{c} \text { cost } \mathrm{c}\end{array}$}} \\
\hline & 1 & 2 & 3 & 1 & 2 & 3 & 4 & 5 & 6 & 7 & & \\
\hline 1 & $\mathrm{Y}$ & $Y$ & $\mathrm{Y}$ & 8 & 8 & 6 & 8 & 0 & 8 & 10 & & \\
\hline 2 & $\mathrm{Y}$ & $Y$ & $Y$ & 8 & 8 & & 8 & 0 & 8 & 8 & & \\
\hline 3 & $\mathrm{Y}$ & $Y$ & $Y$ & 10 & 10 & 8 & 10 & 0 & 10 & 10 & & \\
\hline 4 & $\mathrm{Y}$ & $Y$ & $\mathrm{Y}$ & 8 & 10 & 10 & 10 & 0 & 10 & 8 & & \\
\hline 5 & $\mathrm{Y}$ & $Y$ & $\mathrm{Y}$ & 7 & 10 & 1.7 & 10 & 2 & 10 & 8 & & \\
\hline 6 & $\mathrm{Y}$ & $\mathrm{Y}$ & $\mathrm{Y}$ & 7 & 10 & 10 & 10 & 3 & 10 & 5 & & \\
\hline 7 & $\mathrm{Y}$ & Y & $\mathrm{Y}$ & 8 & 5 & 5 & 8 & $\mathrm{~N} / \mathrm{A}$ & 8 & 10 & & \\
\hline 8 & $Y$ & $Y$ & $Y$ & 9 & 9 & 9 & 10 & 0 & 10 & 9 & & \\
\hline 9 & $Y$ & $Y$ & $Y$ & 5 & 10 & 9 & 8 & 0 & 8 & 6 & & \\
\hline 10 & $Y$ & $Y$ & $Y$ & 10 & 10 & 10 & 5 & 0 & 9 & 10 & & \\
\hline 11 & $\mathrm{Y}$ & Y & $\mathrm{Y}$ & 10 & 9 & 7 & 8 & 0 & 10 & 10 & & \\
\hline 12 & $\mathrm{Y}$ & $Y$ & $\mathrm{Y}$ & 8 & 10 & 8 & 10 & 0 & 8 & 7 & & \\
\hline 13 & $\mathrm{Y}$ & $\mathrm{Y}$ & $Y$ & 10 & 10 & 5 & 10 & 0 & 10 & 10 & & \\
\hline Sum & - & - & - & 108.0 & 119.0 & 88.7 & 115.0 & 5.0 & 119.0 & 111.0 & & \\
\hline Avg. score & - & - & - & 8.3 & 9.2 & 7.4 & 8.8 & 0.4 & 9.2 & 8.5 & & \\
\hline Weight factor & - & - & - & 8.6 & 6.8 & 7.3 & 6.1 & 5.9 & 4.3 & 5.6 & & \\
\hline Weighted score & - & - & - & 71.4 & 62.2 & 54.0 & 54.0 & 2.5 & 39.4 & 47.8 & 331.2 & 277.3 \\
\hline
\end{tabular}

a Technology "musts":

1. Meet VOC treatment goals; 2. Complete demonstration within 5 months; and 3. Meet all permits, safety, \& QA.

b Technology "wants":

1. Assurance of process $\mathrm{R} / \mathrm{O} / \mathrm{M} ; 2$. Minimize secondary waste; 3 . Minimize costs;

4. Minimize occupational exposure and risk to public during demonstration;

5. Remove or destroy VOCs versus immobilize; 6 . Ability to handle non-VOC hazardous components; and 7. Applicability of process to other DOE sites.

$\underline{c}$ Total score is weighted according to total rating per want and the weight assigned to that want. 
Table E.4. Summary of Kepner-Tregoe results for in situ air/steam stripping.

\begin{tabular}{|c|c|c|c|c|c|c|c|c|c|c|c|c|}
\hline \multirow[b]{2}{*}{ Evaluator } & \multicolumn{4}{|c|}{ "Musts" a } & \multicolumn{4}{|c|}{ "Wants" b } & \multirow[b]{2}{*}{6} & \multirow{2}{*}{\multicolumn{2}{|c|}{$\begin{array}{l}\text { Total } \\
\text { score } \mathcal{C}\end{array}$}} & \multirow[t]{2}{*}{$\begin{array}{l}\text { Total } \\
\text { score } \\
\text { w/o } \\
\text { cost } \mathrm{c}\end{array}$} \\
\hline & 1 & 2 & 3 & 1 & 2 & 3 & 4 & 5 & & & & \\
\hline 1 & $\mathrm{Y}$ & $\mathrm{Y}$ & $\mathrm{Y}$ & 7 & 9 & 10 & 10 & 8 & 1 & 10 & & \\
\hline 2 & $\mathrm{Y}$ & $\mathrm{Y}$ & $\mathrm{Y}$ & 5 & 5 & & 5 & 10 & 0 & 8 & & \\
\hline 3 & $Y$ & $\mathrm{Y}$ & $Y$ & 3 & 5 & 8 & 4 & 10 & 10 & 7 & & \\
\hline 4 & $Y$ & $\mathrm{Y}$ & $Y$ & 8 & 6 & 5 & 8 & 10 & 2 & 8 & & \\
\hline 5 & $\mathrm{Y}$ & $\mathrm{Y}$ & $\mathrm{Y}$ & 6 & 8 & 1.6 & 7 & 10 & 7 & 9 & & \\
\hline 6 & $\mathrm{~N}$ & $\mathrm{Y}$ & $\mathrm{Y}$ & 6 & 5 & 5 & 3 & 7 & 0 & 5 & & \\
\hline 7 & $\underline{\mathrm{d}}$ & & & 6 & 9 & 10 & 7 & 8 & 3 & 7 & & \\
\hline 8 & $\mathrm{Y}$ & $\mathrm{Y}$ & $\mathrm{Y}$ & 6.5 & 7 & 6 & 10 & 10 & 5 & 5 & & \\
\hline 9 & $\mathrm{Y}$ & $\mathrm{Y}$ & $\mathrm{Y}$ & 8 & 5 & 10 & 8 & 10 & 4 & 9 & & \\
\hline 10 & $\mathrm{Y}$ & $\mathrm{Y}$ & $\mathrm{Y}$ & 5 & 9 & 10 & 9 & 10 & 0 & 5 & & \\
\hline 11 & Y & $\mathrm{Y}$ & $\mathrm{Y}$ & 10 & 9 & 7 & 10 & 10 & 5 & 10 & & \\
\hline 12 & $Y$ & $Y$ & $\mathrm{Y}$ & 7 & 7 & 5 & 8 & 10 & 0 & 5 & & \\
\hline 13 & $\mathrm{Y}$ & $Y$ & $\mathrm{Y}$ & 8 & 3 & 5 & 9 & 10 & 0 & 10 & & \\
\hline Sum & - & - & - & 85.5 & 87.0 & 82.6 & 98.0 & 123.0 & 37.0 & 98.0 & & \\
\hline Avg. score & - & - & - & 6.6 & 6.7 & 6.9 & 7.5 & 9.5 & 2.8 & 7.5 & & \\
\hline Weight factor & - & - & - & 8.6 & 6.8 & 7.3 & 6.1 & 5.9 & 4.3 & 5.6 & & \\
\hline Weighted score & - & - & - & 56.6 & 45.5 & 50.2 & 46.0 & 55.8 & 12.2 & +2.2 & 308.6 & 258.3 \\
\hline
\end{tabular}

a Technology "musts":

1. Meet VOC treatment goals; 2 . Complete demonstration within 5 months; and

3. Meet all permits, safety, \& QA.

b Technology "wants":

1. Assurance of process $\mathrm{R} / \mathrm{O} / \mathrm{M} ; 2$. Minimize secondary waste; 3 . Minimize costs;

4. Minimize occupational exposure and risk to public during demonstration;

5. Remove or destroy VOCs versus immobilize; 6 . Ability to handle non-VOC

hazardous components; and 7. Applicability of process to other DOE sites.

$\underline{\mathrm{c}}$ Total score is weighted according to total rating per want and the weight assigned to that want.

$\mathrm{d}$ A blank cell indicates information not provided by that evaluator. 
Table E.5. Summary of Kepner-Tregoe results for in situ electrokinetics.

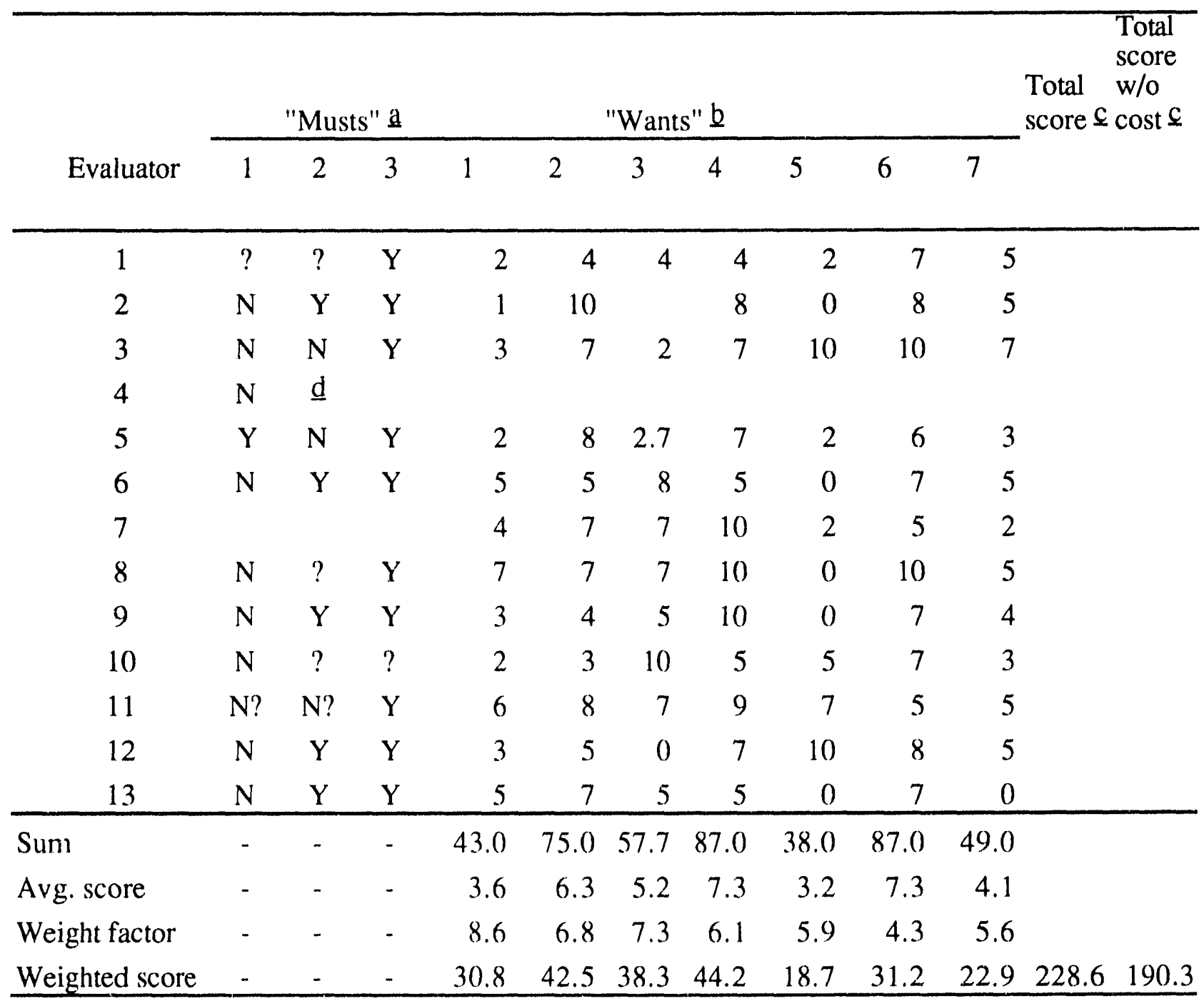

a Technology "musts":

1. Meet VOC treatment goals; 2. Complete demonstration within 5 months; and 3. Meet all permits, safety, \& QA.

b Technology "wants":

1. Assurance of process R/O/M; 2. Minimize secondary waste; 3 . Minimize costs;

4. Minimize occupational exposure and risk to public during demonstration;

5. Remove or destroy VOCs versus immobilize; 6. Ability to handle non-VOC hazardous components; and 7. Applicability of process to other DOE sites.

$\underline{\mathrm{c}}$ Total score is weighted according to total rating per want and the weight assigned to that want.

$\mathrm{d}$ A blank cell indicates information not provided by that evaluator. 
Table E.6. Summary of Kepner-Tregoe results for in situ slurry reactor.

\begin{tabular}{|c|c|c|c|c|c|c|c|c|c|c|c|c|}
\hline \multirow[b]{2}{*}{ Evaluator } & \multicolumn{4}{|c|}{ "Musts" a } & \multicolumn{4}{|c|}{ "Wants" b } & \multirow{2}{*}{\multicolumn{4}{|c|}{$\begin{array}{ll} & \text { Total } \\
\text { score } \\
\text { Total } & \mathrm{w} / \mathrm{o} \\
\text { score } \mathrm{s} \text { cost } \mathrm{c}\end{array}$}} \\
\hline & 1 & 2 & 3 & 1 & 2 & 3 & 4 & 5 & & & & \\
\hline 1 & $\mathrm{Y}$ & Y & $Y$ & 4 & 8 & & 8 & 0 & 7 & 3 & & \\
\hline 2 & $\mathrm{Y}$ & $\mathrm{Y}$ & $\mathrm{Y}$ & 5 & 8 & & 8 & 0 & 8 & 8 & & \\
\hline 3 & $\mathrm{Y}$ & $\mathrm{Y}$ & $\mathrm{Y}$ & 9 & 3 & 4 & 6 & 0 & 9 & 8 & & \\
\hline 4 & $\mathrm{~N}$ & $\mathrm{Y}$ & $Y$ & & & & & & & & & \\
\hline 5 & $Y$ & $\mathrm{Y}$ & $\mathrm{Y}$ & 3 & 8 & & 7 & 10 & 2 & 5 & & \\
\hline 6 & $Y ?$ & $Y$ & $Y$ & 7 & 10 & 8 & 10 & 3 & 10 & 5 & & \\
\hline 7 & $\underline{\mathrm{d}}$ & & & 8 & 5 & 8 & 6 & 3 & 6 & 6 & & \\
\hline 8 & \multicolumn{12}{|c|}{ Same technology as in situ immobilization } \\
\hline 9 & $\mathrm{Y}$ & $Y$ & $\mathrm{Y}$ & 0 & 1 & 5 & 1 & 0 & 6 & 1 & & \\
\hline 10 & Y & $?$ & $?$ & 3 & 3 & & 5 & 0 & 10 & 8 & & \\
\hline 11 & $\mathrm{Y}$ & $\mathrm{Y}$ & $Y$ & 4 & 7 & & 8 & 7 & 5 & 5 & & \\
\hline 12 & $\mathrm{Y}$ & $\mathrm{Y}$ & $\mathrm{Y}$ & 3 & 8 & 8 & 8 & 0 & 10 & 7 & & \\
\hline 13 & $\mathrm{~N}$ & $Y$ & Y & 6 & 5 & 5 & 8 & 0 & 10 & 8 & & \\
\hline Sum & - & - & - & 52.0 & 66.0 & 38.0 & 75.0 & 23.0 & 83.0 & 64.0 & & \\
\hline Avg. score & - & - & - & 4.7 & 6.0 & 6.3 & 6.8 & 2.1 & 7.5 & 5.8 & & \\
\hline Weight factor & - & - & - & 8.6 & 6.8 & 7.3 & 6.1 & 5.9 & 4.3 & 5.6 & & \\
\hline Weighted score & - & - & - & 40.7 & 40.8 & 46.2 & 41.6 & 12.3 & 32.4 & 32.6 & 246.6 & 200.4 \\
\hline
\end{tabular}

a Technology "musts":

1. Meet VOC treatment goals; 2. Complete demonstration within 5 months; and 3. Meet all permits, safety, \& QA.

b Technology "wants":

1. Assurance of process R/O/M; 2. Minimize secondary waste; 3. Minimize costs;

4. Minimize occupational exposure and risk to public during demonstration;

5. Remove or destroy VOCs versus immobilize; 6 . Ability to handle non-VOC hazardous components; and 7. Applicability of process to other DOE sites.

$\underline{\mathrm{c}}$ Total score is weighted according to total rating per want and the weight assigned to that want.

$\mathrm{d}$ A blank cell indicates information not provided by that evaluator. 
Table E.7. Summary of Kepner-Tregoe results for in situ RF/EM heating.

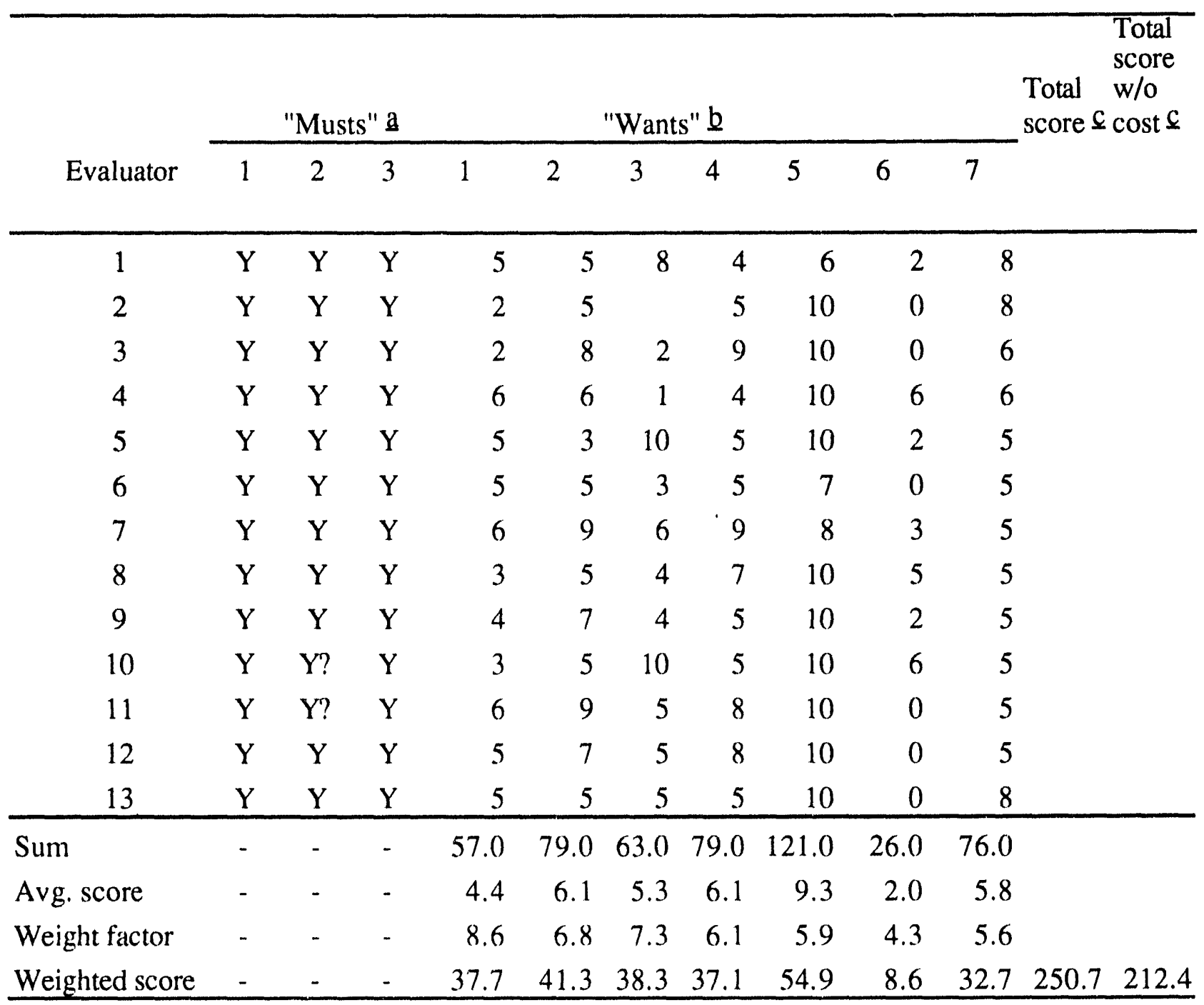

a Technology "musts":

1. Meet VOC treatment goals; 2. Complete demonstration within 5 months; and 3. Meet all permits, safety, \& QA.

b Technology "wants":

1. Assurance of process R/O/M; 2. Minimize secondary waste; 3 . Minimize costs;

4. Minimize occupational exposure and risk to public during demonstration;

5. Remove or destroy VOCs versus immobilize; 6 . Ability to handle non-VOC hazardous components; and 7. Applicability of process to other DOE sites.

$\underline{\mathrm{c}}$ Total score is weighted according to total rating per want and the weight assigned to that want. 
Table E.8. Summary of Kepner-Tregoe results for in situ / ex situ peroxide stripping.

\begin{tabular}{|c|c|c|c|c|c|c|c|c|c|c|c|c|}
\hline \multirow[b]{2}{*}{ Evaluator } & \multicolumn{4}{|c|}{ "Musts" a } & \multicolumn{4}{|c|}{ "Wants" b } & \multirow[b]{2}{*}{6} & \multirow[b]{2}{*}{7} & \multirow{2}{*}{\multicolumn{2}{|c|}{$\begin{array}{l}\text { Total } \\
\text { score } \\
\text { Total } \mathrm{w} / \mathrm{o} \\
\text { score } \mathrm{\&} \operatorname{cost} \mathrm{\&}\end{array}$}} \\
\hline & 1 & 2 & 3 & 1 & 2 & 3 & 4 & 5 & & & & \\
\hline 1 & $\mathrm{Y}$ & $?$ & $\mathrm{Y}$ & 9 & 9 & & 8 & 10 & 0 & 10 & & \\
\hline 2 & $\mathrm{Y}$ & $\mathrm{Y}$ & $\mathrm{Y}$ & 5 & 5 & & 3 & 8 & 3 & 10 & & \\
\hline 3 & $\mathrm{Y}$ & $\mathrm{Y}$ & $\mathrm{Y}$ & 10 & 5 & 8 & 7 & 10 & 0 & 8 & & \\
\hline 4 & $\mathrm{Y}$ & $\mathrm{Y}$ & $\mathrm{Y}$ & 8 & 8 & 5 & 6 & 10 & 6 & 8 & & \\
\hline 5 & $\mathrm{Y}$ & $\mathrm{Y}$ & $\mathrm{Y}$ & 10 & 8 & & 6 & 10 & 7 & 9 & & \\
\hline 6 & $\mathrm{Y}$ & $\mathrm{Y}$ & Y & 6 & 5 & 5 & 3 & 7 & 0 & 5 & & \\
\hline 7 & $\underline{d}$ & & & 5 & 1 & 3 & 3 & 0 & 8 & 3 & & \\
\hline 8 & $Y$ & $\mathrm{Y}$ & $Y$ & 10 & 7 & & 5 & 10 & 5 & 5 & & \\
\hline 9 & $\mathrm{Y}$ & $Y$ & $\mathrm{Y}$ & 7 & 6 & 5 & 6 & 10 & 3 & 8 & & \\
\hline 10 & $Y$ & Y & $Y$ & 7 & 9 & & 9 & 10 & 5 & 5 & & \\
\hline 11 & $Y$ & Y & Y & 10 & 9 & 7 & 5 & 7 & 5 & 5 & & \\
\hline 12 & $Y$ & Y & Y & 8 & 10 & 4 & 7 & 10 & 2 & 5 & & \\
\hline 13 & $\mathrm{Y}$ & $\mathrm{Y}$ & $\mathrm{Y}$ & 10 & 9 & 5 & 9 & 10 & 0 & 10 & & \\
\hline Sum & - & - & - & 105.0 & 91.0 & 42.0 & $7 i .0$ & 112.0 & 44.0 & 91.0 & & \\
\hline Avg. score & - & - & - & 8.1 & 7.0 & 5.3 & 5.9 & 8.6 & 3.4 & 7.0 & & \\
\hline Weight factor & - & - & - & 8.6 & 6.8 & 7.3 & 6.1 & 5.9 & 4.3 & 5.6 & & \\
\hline Weighted score & - & - & - & 69.5 & 47.6 & 38.3 & 36.1 & 50.8 & 14.6 & 39.2 & 296.1 & 257.8 \\
\hline
\end{tabular}

a Technology "musts":

1. Meet VOC treatment goals; 2. Complete demonstration within 5 months; and

3. Meet all permits, safety, \& QA.

b Technology "wants":

1. Assurance of process R/O/M;2. Minimize secondary waste; 3 . Minimize costs;

4. Minimize occupational exposure and risk to public during demonstration;

5. Remove or destroy VOCs versus immobilize; 6 . Ability to handle non-VOC hazardous components; and 7. Applicability of process to other DOE sites.

$\underline{\mathrm{c}}$ Total score is weighted according to total rating per want and the weight assigned to that want.

$\mathrm{d}$ A blank cell indicates information not provided by that evaluator. 
Table E.9. Summary of Kepner-Tregoe results for ex situ thermal treatment.

\begin{tabular}{|c|c|c|c|c|c|c|c|c|c|c|c|c|}
\hline \multirow[b]{2}{*}{ Evaluator } & \multicolumn{4}{|c|}{ "Musts" a } & \multicolumn{4}{|c|}{ "Wants" b } & \multirow[b]{2}{*}{6} & & \multirow{2}{*}{\multicolumn{2}{|c|}{$\begin{array}{ll} & \text { Total } \\
\text { score } \\
\text { Total } \quad \text { w/o } \\
\text { score } \mathrm{c} \operatorname{cost} \mathrm{c}\end{array}$}} \\
\hline & 1 & 2 & 3 & 1 & 2 & 3 & 4 & 5 & & 7 & & \\
\hline 1 & $\mathrm{Y}$ & $\mathrm{Y}$ & $Y$ & 10 & 10 & 2 & 7 & 10 & 4 & 10 & & \\
\hline 2 & $Y$ & $Y$ & $Y$ & 8 & 5 & & 3 & 10 & 3 & 9 & & \\
\hline 3 & $\mathrm{Y}$ & $\mathrm{Y}$ & $Y$ & 2 & 4 & 1 & 6 & 10 & 3 & 5 & & \\
\hline 4 & $\mathrm{Y}$ & $\mathrm{Y}$ & $Y$ & 8 & 6 & 5 & 6 & 10 & 6 & 10 & & \\
\hline 5 & $Y$ & $\mathrm{Y}$ & $Y$ & 7 & 8 & 1.6 & 7 & 10 & 7 & 8 & & \\
\hline 6 & $\mathrm{Y}$ & $Y$ & $Y$ & 10 & 5 & 8 & 5 & 10 & 0 & 5 & & \\
\hline 7 & $\mathrm{Y}$ & $\mathrm{Y}$ & $Y$ & 10 & 10 & 9 & 4 & 10 & 3 & 10 & & \\
\hline 8 & $\mathrm{Y}$ & $\mathrm{Y}$ & $Y$ & 8 & 9 & 6 & 5 & 10 & 5 & 5 & & \\
\hline 9 & $\mathrm{Y}$ & $Y$ & $Y$ & 10 & 8 & 5 & 4 & 10 & 5 & 10 & & \\
\hline 10 & $\mathrm{Y}$ & $\mathrm{Y}$ & $Y$ & 4 & 8 & 2.5 & 7 & 10 & 0 & 5 & & \\
\hline 11 & $\mathrm{Y}$ & $\mathrm{Y}$ & $Y$ & 10 & 9 & 7 & 5 & 10 & 5 & 5 & & \\
\hline 12 & $\mathrm{Y}$ & $\mathrm{Y}$ & $Y$ & 10 & 7 & 4 & 6 & 10 & 0 & 5 & & \\
\hline 13 & $\mathrm{Y}$ & $\mathrm{Y}$ & $Y$ & 10 & 5 & 5 & 8 & 10 & 0 & 10 & & \\
\hline Sum & - & - & - & 107.0 & 94.0 & 56.1 & 73.0 & 130.0 & 41.0 & 97.0 & & \\
\hline Avg. score & - & - & - & 8.2 & 7.2 & 4.7 & 5.6 & 10.0 & 3.2 & 7.5 & & \\
\hline Weight factor & - & - & - & 8.6 & 6.8 & 7.3 & 6.1 & 5.9 & 4.3 & 5.6 & & \\
\hline Weighted score & - & - & - & 70.8 & 49.2 & 34.1 & 34.3 & 59.0 & 13.6 & 41.8 & 302.7 & 268.6 \\
\hline
\end{tabular}

a Technology "musts":

1. Meet VOC treatment goals; 2. Complete demonstration within 5 months; and

3. Meet all permits, safety, \& QA.

b Technology "wants":

1. Assurance of process R/O/M; 2. Minimize secondary waste; 3 . Minimize costs;

4. Minimize occupational exposure and risk to public during demonstration;

5. Remove or destroy VOCs versus immobilize; 6. Ability to handle non-VOC hazardous components; and 7. Applicability of process to other DOE sites.

$\underline{\mathrm{c}}$ Total score is weighted according to total rating per want and the weight assigned to that want. 
Table E.10. Summary of Kepner-Tregoe results for ex situ immobilization.

\begin{tabular}{|c|c|c|c|c|c|c|c|c|c|c|c|c|}
\hline \multirow[b]{2}{*}{ Evaluatoi } & \multicolumn{4}{|c|}{ "Musts" a } & \multicolumn{4}{|c|}{ "Wants" b } & \multirow{2}{*}{\multicolumn{4}{|c|}{$\begin{array}{ll} & \text { Total } \\
& \text { score } \\
\text { Total } & \text { w/o } \\
\text { score } \mathrm{s} \operatorname{cost} \mathrm{c}\end{array}$}} \\
\hline & 1 & 2 & 3 & 1 & 2 & 3 & 4 & 5 & & & & \\
\hline 1 & $\mathrm{Y}$ & $\mathrm{Y}$ & $\mathrm{Y}$ & 9 & 8 & 6 & 7 & 0 & 10 & 10 & & \\
\hline 2 & $\mathrm{Y}$ & $\mathrm{Y}$ & $\mathrm{Y}$ & 8 & 5 & & 3 & 0 & 8 & 10 & & \\
\hline 3 & $\mathrm{Y}$ & $\mathrm{Y}$ & $\mathrm{Y}$ & 10 & 4 & 9 & 7 & 0 & 10 & 6 & 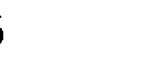 & \\
\hline 4 & $\mathrm{Y}$ & $\mathrm{Y}$ & $\mathrm{Y}$ & 10 & 10 & 5 & 6 & 0 & 10 & 10 & & \\
\hline 5 & $\mathrm{Y}$ & $\mathrm{Y}$ & $\mathrm{Y}$ & 7 & 9 & 4.4 & 7 & 5 & 10 & 8 & & \\
\hline 6 & $\mathrm{Y}$ & $\mathrm{Y}$ & $\mathrm{Y}$ & 10 & 7 & 10 & 7 & 3 & 10 & 5 & & \\
\hline 7 & $\mathrm{Y}$ & $\mathrm{Y}$ & $\mathrm{Y}$ & 10 & 5 & 4 & 5 & N/A & 10 & 10 & & \\
\hline 8 & $\mathrm{Y}$ & $\mathrm{Y}$ & $\mathrm{Y}$ & 10 & 9 & 10 & 5 & 2 & 10 & 10 & & \\
\hline 9 & $\mathrm{Y}$ & $Y$ & $Y$ & 6 & 9 & 7 & 6 & 0 & 10 & 7 & & \\
\hline 10 & $\mathrm{Y}$ & $\mathrm{Y}$ & $\mathrm{Y}$ & 10 & 10 & 10 & 7 & 0 & 10 & 10 & & \\
\hline 11 & $\mathrm{Y}$ & $Y ?$ & $\mathrm{Y}$ & 10 & 9 & 7 & 5 & 0 & 10 & 5 & & \\
\hline 12 & $\mathrm{Y}$ & $Y$ & $\mathrm{Y}$ & 10 & 8 & 3 & 7 & 0 & 10 & 7 & & \\
\hline 13 & $\mathrm{Y}$ & $\mathrm{Y}$ & $Y$ & 10 & 10 & 5 & 10 & 0 & 10 & 10 & & \\
\hline Sum & - & - & - & 120.0 & 103.0 & 80.4 & 82.0 & 10.0 & 128.0 & 108.0 & & \\
\hline Avg. score & - & - & - & 9.2 & 7.9 & 6.7 & 6.3 & 0.8 & 9.8 & 8.3 & & \\
\hline Weight factor & - & - & - & 8.6 & 6.8 & 7.3 & 6.1 & 5.9 & 4.3 & 5.6 & & \\
\hline Weighted score & - & - & - & 79.4 & 53.9 & 48.9 & 38.5 & 4.9 & 42.3 & 46.5 & 314.4 & 265.5 \\
\hline
\end{tabular}

a Technology "musts":

1. Meet VOC treatment goals; 2. Complete demonstration within 5 months; and 3. Meet all permits, safety, \& QA.

b Technology "wants":

1. Assurance of process R/O/M;2. Minimize secondary waste; 3 . Minimize costs;

4. Minimize occupational exposure and risk to public during demonstration;

5. Remove or destroy VOCs versus immobilize; 6 . Ability to handle non-VOC hazardous components; and 7. Applicability of process to other DOE sites.

$\underline{\mathrm{c}}$ Total score is weighted according to total rating per want and the weight assigned to that want. 


\section{INTERNAL DISTRIBUTION}

$\begin{array}{ll}\text { 1. } & \text { R. O. Barnett, Jr. } \\ 2 . & \text { L.D. Bates } \\ 3 . & \text { D. A. Bell } \\ 4 . & \text { H. L. Boston } \\ \text { 5. } & \text { C. H. Brown } \\ 6 . & \text { J. B. Cannon } \\ 7 . & \text { J. H. Cushman } \\ 8 . & \text { N. H. Cutshall } \\ 9 . & \text { T. L. Donaldson } \\ 10 . & \text { T. O. Early } \\ 11 . & \text { W. Fulkerson } \\ 12 . & \text { D. D. Gates } \\ 13 . & \text { C. W. Gehrs } \\ 14 . & \text { T. M. Gilliam } \\ 15 . & \text { D. W. Greene } \\ 16 . & \text { S. E. Herbes } \\ 17 . & \text { S. G. Hildebrand } \\ 18 . & \text { R. A. Jenkins } \\ 19 . & \text { H. L. Jennings } \\ 20 . & \text { P. Kanciruk } \\ 21 . & \text { A. J. Lucero } \\ 22 . . & \text { A. P. Malinauskas }\end{array}$

$\begin{array}{ll}23 . & \text { T. McKnight } \\ 24 . & \text { T. J. Mitchell } \\ 25 . & \text { M. I. Morris } \\ 26 . & \text { C. A. Muhr } \\ 27 . & \text { D. A. Pickering } \\ 28 . & \text { D. E. Reichle } \\ 29 & \text { W. Sanford } \\ 30 . & \text { F. E. Sharples } \\ 31 . & \text { D. S. Shriner } \\ 32-36 . & \text { R. L. Siegrist } \\ 37 . & \text { S. H. Stow } \\ 38 . & \text { R. I. Van Hook } \\ 39 . & \text { J. S. Watson } \\ 40 . & \text { O. R. West } \\ 41 . & \text { Central Research Library } \\ 42-44 . & \text { ESU Library } \\ 45 . & \text { ORNL Y-12 Technical Library } \\ & \text { Document Reference Section } \\ 46-47 . & \text { Laboratory Records } \\ 48 . & \text { Laboratory Records, RC } \\ 49 . & \text { ORNL Patent Section }\end{array}$

\section{EXTERNAL DISTRIBUTION}

50-54. D. T. Davenport, Environmental Restoration Division, Martin Marietta Energy Systems, Portsmouth Gaseous Diffusion Plant, MS 5025, Piketon, Ohio.

55-56. R. D'Antoni, Chemical Engineering, Portsmouth Gaseous Diffusion Plant, MS 5025, Piketon, Ohio.

57. Jeff Dick, SAIC, Portsmouth Gaseous Diffusion Plant, Piketon, Ohio.

58. R. N. Farvolden, Professor, Department of Earth Sciences, University of Water, Ontario N2L 3G1 Canada.

59. J. F. Franklin, Bloedel Professor of Ecosystem Analysis, College of Forest Resources, University of Washington, Anderson Hall AR-10, Seattle, WA 98195.

60. J. S. Gierke, Assistant Professor, Michigan Technological University, 1400 Townsend Drive, Houghton, MI 49931-1295.

61. D. Geiser, Office of Technology Development, International Technology Exchange Program, EM-53, U. S. Department of Energy, Washington, D.C. 20585

62. R. C. Harriss, Institute for the Study of Earth, Oceans, and Space, Science and Engineering Research Building, University of New Hampshire, Durham, NH 03824.

63. G. Y. Jordy, Director, Office of Program Analysis, Office of Energy Research, ER-30, G-226, U.S. Department of Energy, Washington, DC 20545.

64. P. M. Kearl, ORNL Grand Junction Office, 2597 B 3/4 Road, Grand Junction, Colorado 81502.

65. R. Meehan, DOE Environmental Restoration, Portsmouth Gaseous Diffusion Plant, Piketon, Ohio.

66. Dave Mentzer, SAIC, Portsmouth Gaseous Diffusion Plant, Piketon, Ohio.

67. R. H. Olsen, Professor, Microbiology and Immunology Department, University of Michigan, Medical Sciences II, \#5605, 1301 East Catherine Street, Ann Arbo, MI 48109-0620. 
68. A. Patrinos, Director, Environmental Sciences Division, Office of Health and Environmental Research, ER-74, U.S. Department of Energy, Washington, DC 20585.

69. K. G. Robinson, Assistant Professor, The University of Tennessee, Perkins Hall, Knoxville, TN 37996-2010.

70. F. J. Wobber, Environmental Sciences Division, Office of Health and Environmental Research, ER-74, U.S. Department of Energy, Washington, DC 20585.

71. J. Zutman, ORNL Grand Junction Office, 2597 B 3/4 Road, Grand Junction, Colorado 81502.

72. Office of Assistant Manager for Energy Research and Development, U.S. Department of Energy Oak Ridge Operations, P.O. Box 2001, Oak Ridge, TN 37831-8600.

73-74. Office of Scientific and Technical Information, P.O. Box 62, Oak Ridge, Tennessee 37831 

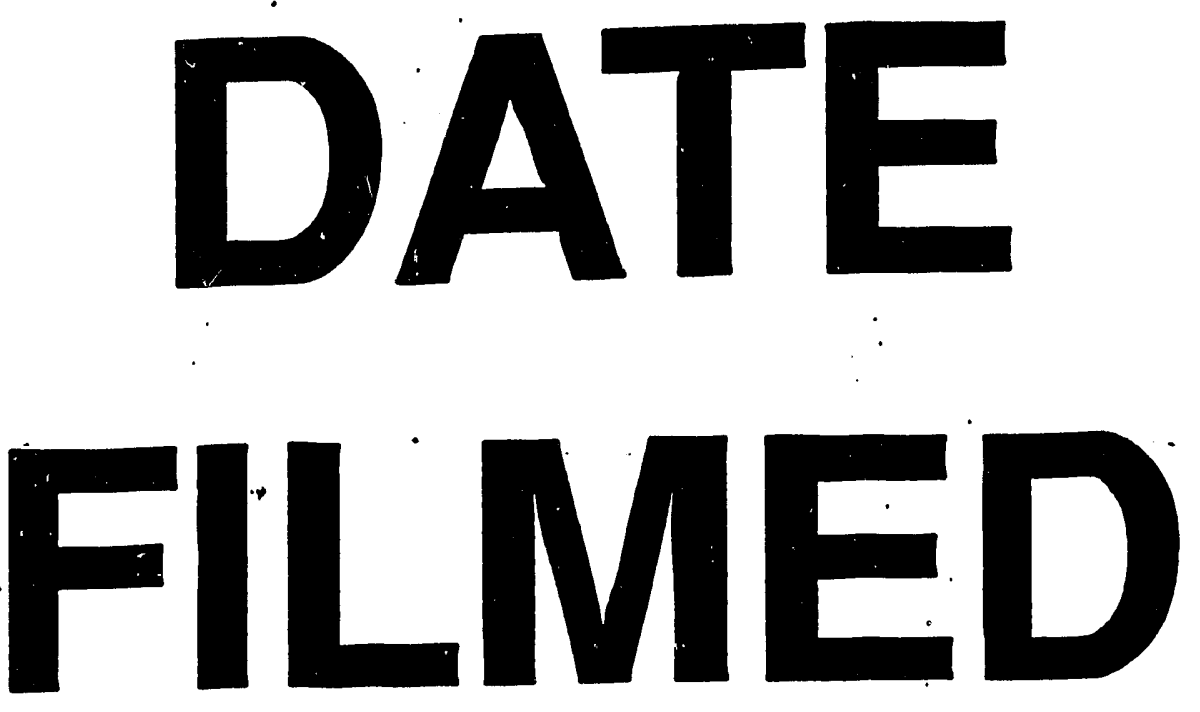

12
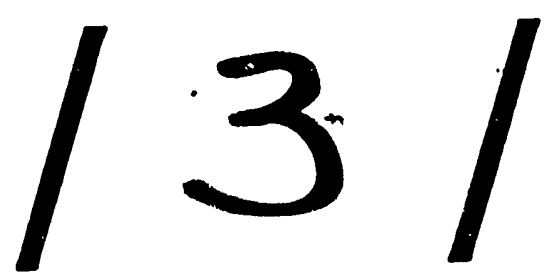

93
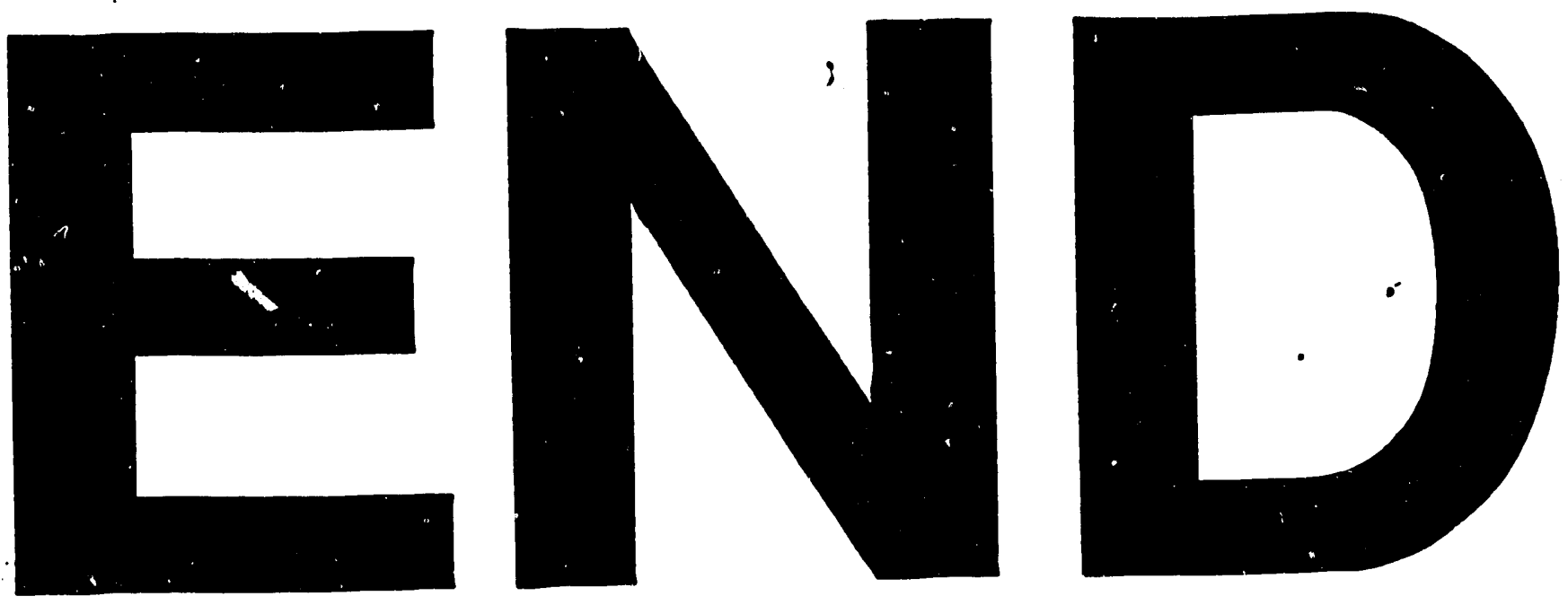


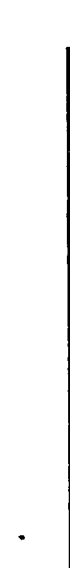

